\title{
TRANSFORMAÇÃO AMBIENTAL E PAISAGÍSTICA NA BAIXADA SANTISTA, SP
}

\section{Cintia Maria Afonso}

Arquiteta, mestra em ciência ambiental pelo PROCAM-USP, doutora em arquitetura e urbanismo pela FAUUSP e professora titular dos cursos de Arquitetura e Urbanismo das Faculdades Armando Álvares Penteado e da Universidade Paulista.

E-mail:cintiafo@osite.com.br

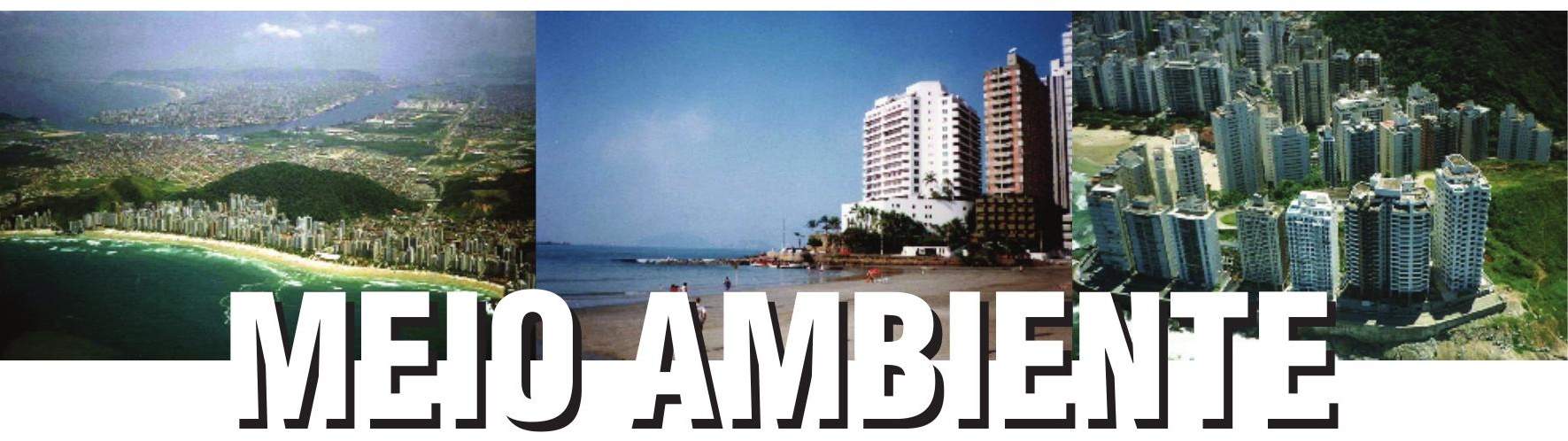




\title{
RESUMO
}

A expansão da região metropolitana da Baixada Santista e das extensas áreas de veraneio, situadas na zona costeira do estado de São Paulo, tem transformado a paisagem natural composta por exuberantes florestas tropicais.

Padrões extensivos de urbanização têm sido repetidos por toda a região, promovidos por meio do parcelamento isolado de glebas situadas em terrenos planos e não-inundáveis, adensadas somente quando ocorre uma sensível valorização da terra. Esse adensamento das áreas mais valorizadas é complementado pelo parcelamento dos terrenos íngremes e alagadiços, o que ocorre somente quando seu valor justifica os investimentos necessários à transformação paisagística.

Palavras-chave: Zona costeira, planejamento da paisagem, gerenciamento costeiro, paisagem regional, Baixada Santista.

\begin{abstract}
On the coastal zone of São Paulo State, both the Baixada Santista metropolitan region and tourist areas developed near the beaches are transforming the original rainforest landscape.

Extensive urban patterns are constantly repeated throughout the region, with plain and dry land parceled out. When land prices increases, these urban areas are transformed by the construction of buildings. As part of this urban expansion process, sloppy and marshy land is also parceled out, however this only happens when its value is worth the investment.
\end{abstract}

Key words: Coastal zone, landscape planning, coastal management, regional landscape, Baixada Santista. 


\section{TRANSFORMAÇÃO AMBIENTAL E PAISAGÍSTICA NA BAIXADA SANTISTA, SPI}

\section{Introdução}

No estado de São Paulo, a Serra do Mar se constitui em divisor natural entre a drenagem atlântica e o sistema hidrográfico do planalto, configurando uma zona costeira estreita, com pequena planície sedimentar só alargada ao sul, no vale do rio Ribeira de lguape.

Essa configuração e a baixa adequação das terras à agricultura fizeram com que a zona costeira paulista fosse superada pelo planalto para os assentamentos urbanos coloniais. As vilas fundadas no início da colonização européia permaneceram funcionando como ligações entre o interior produtivo e Portugal. Subsistiam por conta de seus portos, principal conexão de pessoas e mercadorias entre Brasil e Europa.

Essa organização urbana em pequenos núcleos portuários modificou-se com a construção da ferrovia São Paulo Railway, no final do século XIX, que uniu São Paulo a Santos (a melhor e mais próxima saída portuária para a cidade de São Paulo), favorecendo economicamente toda a Baixada Santista. A partir de então esta região se urbanizou de modo intimamente ligado ao desenvolvimento da cidade de São Paulo e interior, inicialmente com o incremento de atividades portuárias e comerciais ligadas à cultura cafeeira e, posteriormente, complementando o parque industrial paulista com o complexo petroquímico e siderúrgico de Cubatão. Esse processo, vinculado à melhoria dos meios de transporte, favoreceu a Baixada Santista em detrimento do restante do litoral que permaneceu à margem do processo de urbanização até que a busca das praias para o lazer modificasse esse quadro.

A partir da década de 1950, um intenso processo de parcelamento do solo e construção de segundas residências, associado à expansão da rede rodoviária estadual, urbanizou a planície litorânea próxima ao mar, transformando dunas e restingas em um contínuo urbano linear que se estende por muitos quilômetros nas praias, só interrompido por obstáculos geográficos como morros e manguezais. As classes de baixa renda se situaram nos setores urbanos pouco valorizados, geralmente distantes do centro urbano ou sobre áreas legalmente protegidas. Nesses locais se instalam e continuamente expandem-se bairros residenciais pobres, carentes de infra-estrutura como arruamento, água e esgoto, constituídos por subhabitações.

(1) $\bigcirc$ texto apresentado foi extraído da tese de doutorado A paisagem da Baixada Santista: Urbanização, transformação e conservação, defendida na FAUUSP, sob orientação do Prof. Dr. Silvio Soares Macedo. 
Assim, na Baixada Santista a distribuição da urbanização está diretamente vinculada ao processo de valorização da terra urbana e de sua distribuição pelos diferentes segmentos da sociedade. No entanto, a configuração física regional permitiu que extensas áreas florestadas fossem mantidas, situadas nas áreas mais desfavoráveis à urbanização, como as encostas íngremes da Serra do Mar, os manguezais situados no estuário e as áreas cobertas por vegetação de restinga as quais estão distantes das praias.

padrão de parcelamento do solo predominante é constituído por malha viária regular, com quadras totalmente parceladas em lotes de dimensões, apenas suficientes para a construção de residências unifamiliares ou pequenos edifícios, e pela ausência ou escassez de praças e espaços livres públicos que não sejam aqueles necessários à circulação.

A partir desses fatores predomina um padrão de urbanização extensivo, pouco verticalizado, por meio do qual são supridas as necessidades espaciais básicas de circulação, acesso, moradia, comércio e serviços, ao mesmo tempo em que são maximizados os lucros, já que todos os espaços não-voltados à circulação são comercializáveis. Como esses padrões de urbanização são incompatíveis com a manutenção da vegetação nativa, a cobertura vegetal preexistente é completamente eliminada e os padrões de drenagem são alterados, desconsiderando totalmente as condições locais e levando à transformação radical da dinâmica natural e da paisagem.

\section{Processo de Expansão Urbana}

Na região da Baixada Santista as principais atividades econômicas são industriais, (localizadas predominantemente no município de Cubatão), portuárias (situadas em Santos) e de veraneio (em todos os municípios, à exceção de Cubatão que, sem praias, não é procurado para turismo).

A urbanização se concentra, principalmente, na llha de São Vicente, na qual estão situados o centro de Santos, a maior parte do porto e boa parte das áreas residenciais de classe média. A partir da ilha, a área urbana tem se expandido de forma descontínua no interior da planície costeira (onde se situam as áreas residenciais dos trabalhadores de baixo poder aquisitivo) e de forma linear nas praias (onde se situam os loteamentos turísticos). Destaca-se, na mancha urbana, o complexo petroquímico de Cubatão, localizado a meio caminho do porto e da cidade de São Paulo, nos terrenos planos próximos às estradas, ferrovias e cursos d'água. A esse complexo tem se associado loteamentos populares formais e informais que ocupam, preferencialmente, as terras públicas, dada a escassez de terrenos e os baixos salários dos trabalhadores do complexo industrial.

Assim, os municípios de Cubatão, Santos, São Vicente e o distrito de Vicente de Carvalho constituem um bloco urbano interligado que apresenta mancha urbana 
descontínua devido aos canais do estuário e manguezais. Já os municípios de Guarujá, Bertioga e Praia Grande formam um outro grupo no qual predominam as atividades de veraneio, com mancha urbana nitidamente linear.

Figura 1:

Urbanização na

Baixada Santista

Fonte: Base

Aerofotogrametria,

1994

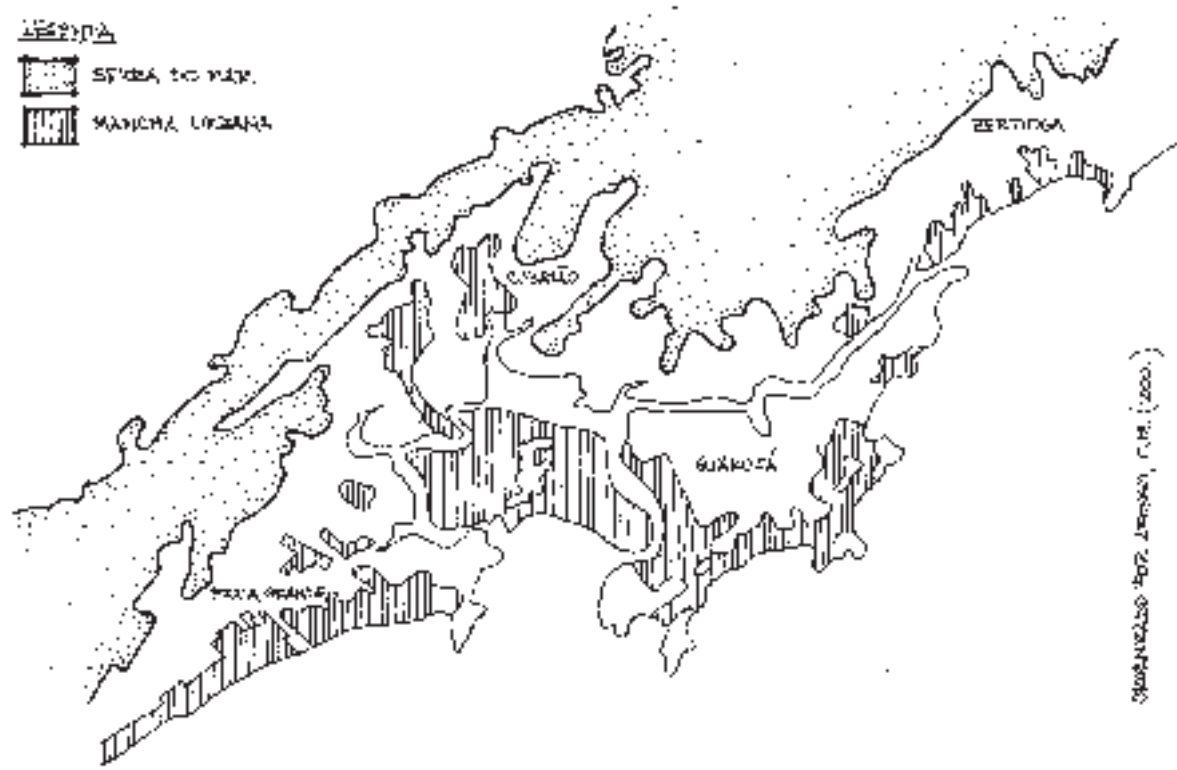

No processo de expansão urbana, as áreas preferencialmente loteadas têm sido as áreas planas, urbanizadas gleba a gleba, apresentando formatos variados e malhas viárias também variadas que se justapõem, formando uma colcha de retalhos composta por parcelas concebidas isoladamente. $O$ desenho das glebas tende ao xadrez, mas se adapta às condições topográficas e fundiárias, buscando a exploração mais vantajosa da porção de terra a lotear, tendo

Figura 2:

Parcelamento do

solo em porção

litorânea do

município de Praia

Grande

Fonte: Praia

Grande, P. M.

Planta Geral do

Município, sd

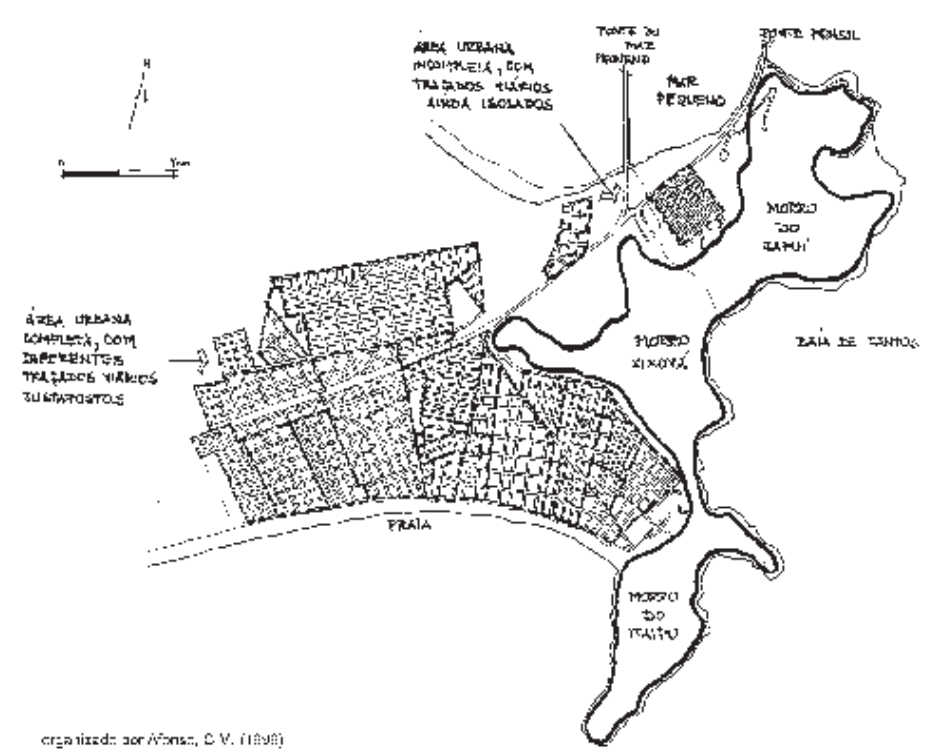


como resultado um conjunto heterogêneo de quadras e vias públicas. $\bigcirc$ esquema apresentado a seguir permite visualizar o processo mencionado para o trecho da Praia Grande mais próximo à Ilha de São Vicente.

Em uma primeira fase do processo de urbanização criam-se vários loteamentos autônomos, arbitrariamente justapostos ou separados por vazios correspondentes a glebas de outros proprietários ou a terras de difícil utilização. Na segunda etapa, as glebas vazias se valorizam por estarem, agora, próximas ao centro ou a outras áreas já urbanizadas, ou por terem recebido melhoramentos públicos, sendo ocupados os terrenos difíceis, já que, agora, o investimento poderia ser revertido em lucro.

Os esquemas apresentados a seguir são indicativos desse processo. $\mathrm{Na}$ Praia Grande e na porção continental de São Vicente, por exemplo, os terrenos urbanos loteados ainda ocupam somente a planície sedimentar, mais favorável à urbanização, e os manguezais ainda se encontram conservados. $\bigcirc$ mesmo não acontece na porção insular de São Vicente onde, após a ocupação das planícies mais secas, manguezais foram invadidos e aterrados para construção de novos loteamentos residenciais ou para expansão das áreas portuárias, restando pequena parte dos mesmos livres de ocupação urbana.

Assim, a expansão e a subseqüente valorização das terras urbanas ocorreram a partir do núcleo polarizador constituído pelo porto e pelo atual centro de

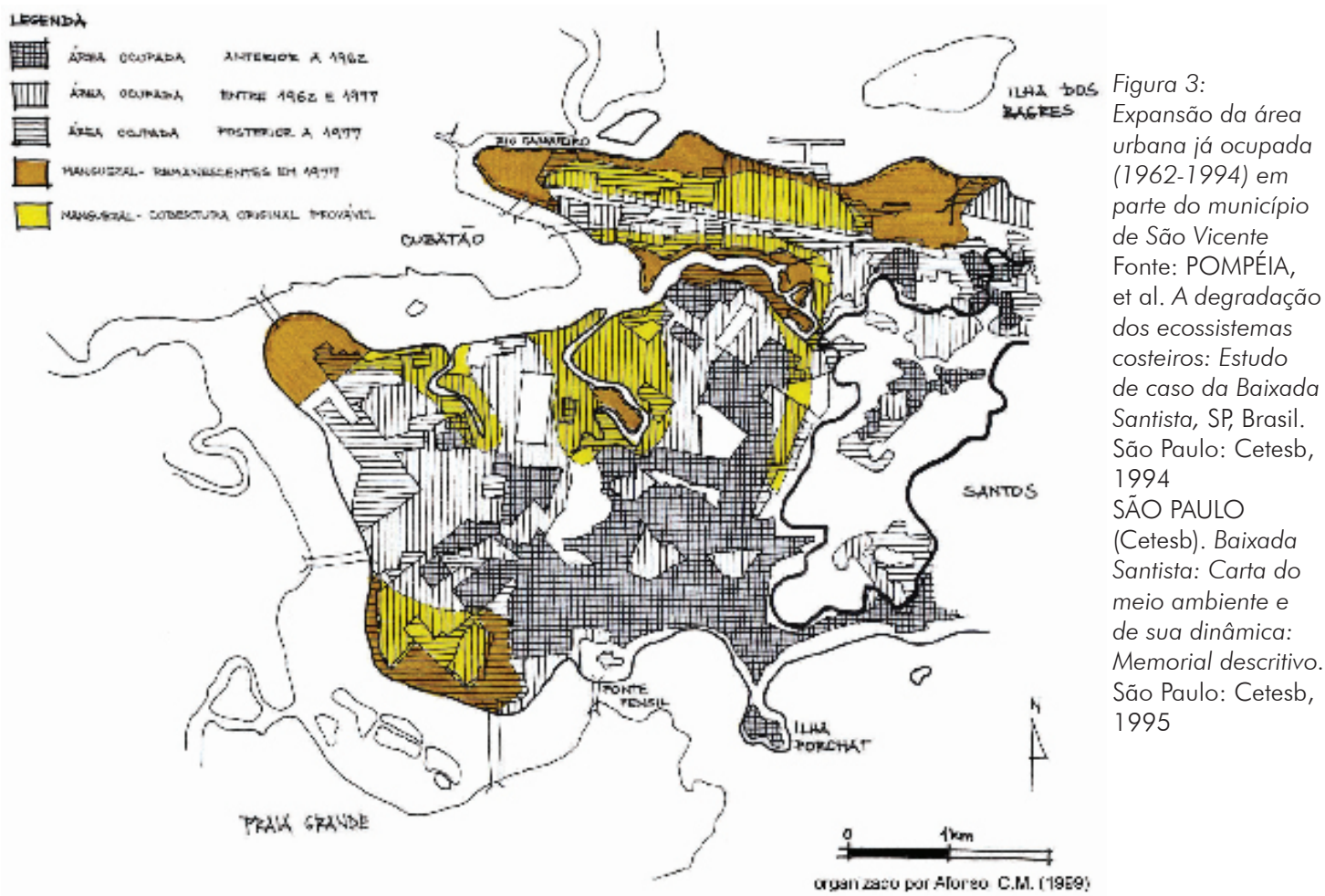




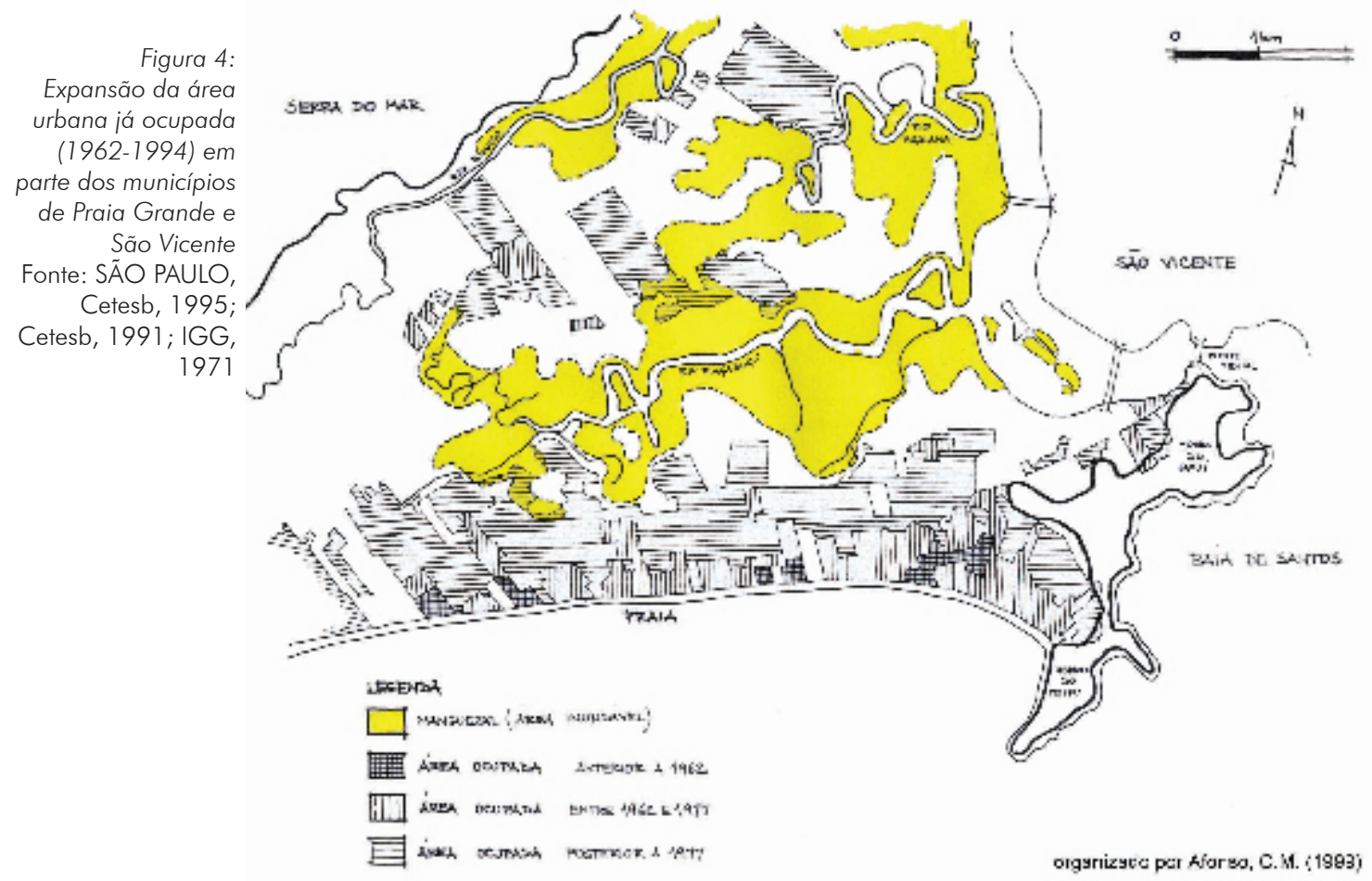

Santos, dirigindo-se, inicialmente, rumo às praias e barra de Santos, em um processo organizado e, posteriormente, em duas direções opostas, rumo a São Vicente e a Vicente de Carvalho, áreas ocupadas sem nenhum plano geral.

\section{Processo de Transformação Ambiental e Paisagística}

Em uma visão geral, o processo de transformação ambiental e paisagística apresenta três momentos principais: inicialmente, glebas de diferentes proprietários são loteadas independentemente e áreas florestadas intercalam os loteamentos recém-implantados (Foto 1); em um segundo momento, as áreas planas são totalmente parceladas e os remanescentes florestais se restringem aos morros ou manguezais (Foto 2); por último, ocorre a verticalização das áreas planas anteriormente parceladas, em geral, mantendo-se os mesmos lotes que são, no máximo, remembrados (Foto 3).

A construção do Complexo Industrial Naval do Guarujá (CING), no Canal de Santos, exemplifica o caráter da transformação ambiental e paisagística em termos locais. Para a implantação do complexo, os pequenos rios foram dragados e retificados e, após a remoção completa das árvores de mangue, os sedimentos de fundo e materiais retirados das áreas próximas do Morro da Barra foram utilizados no aterro das áreas alagadiças inadequadas às construções convencionais. 


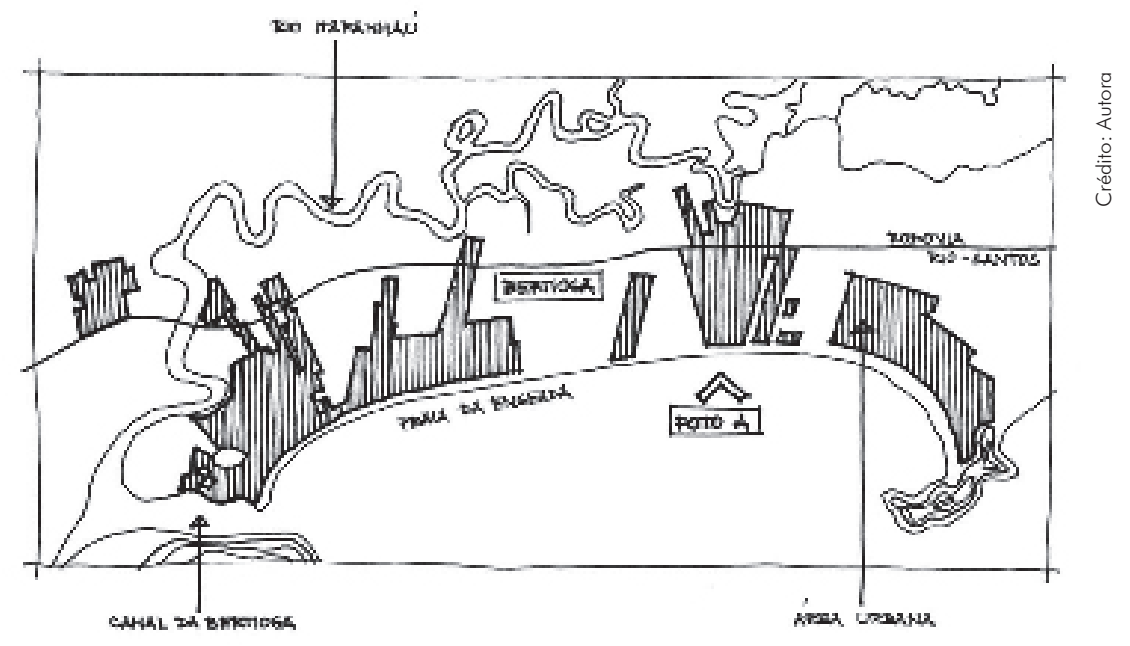

Figura 5 e Foto 1: Vegetação de restinga convive com loteamentos turísticos no município de Bertioga (1998)
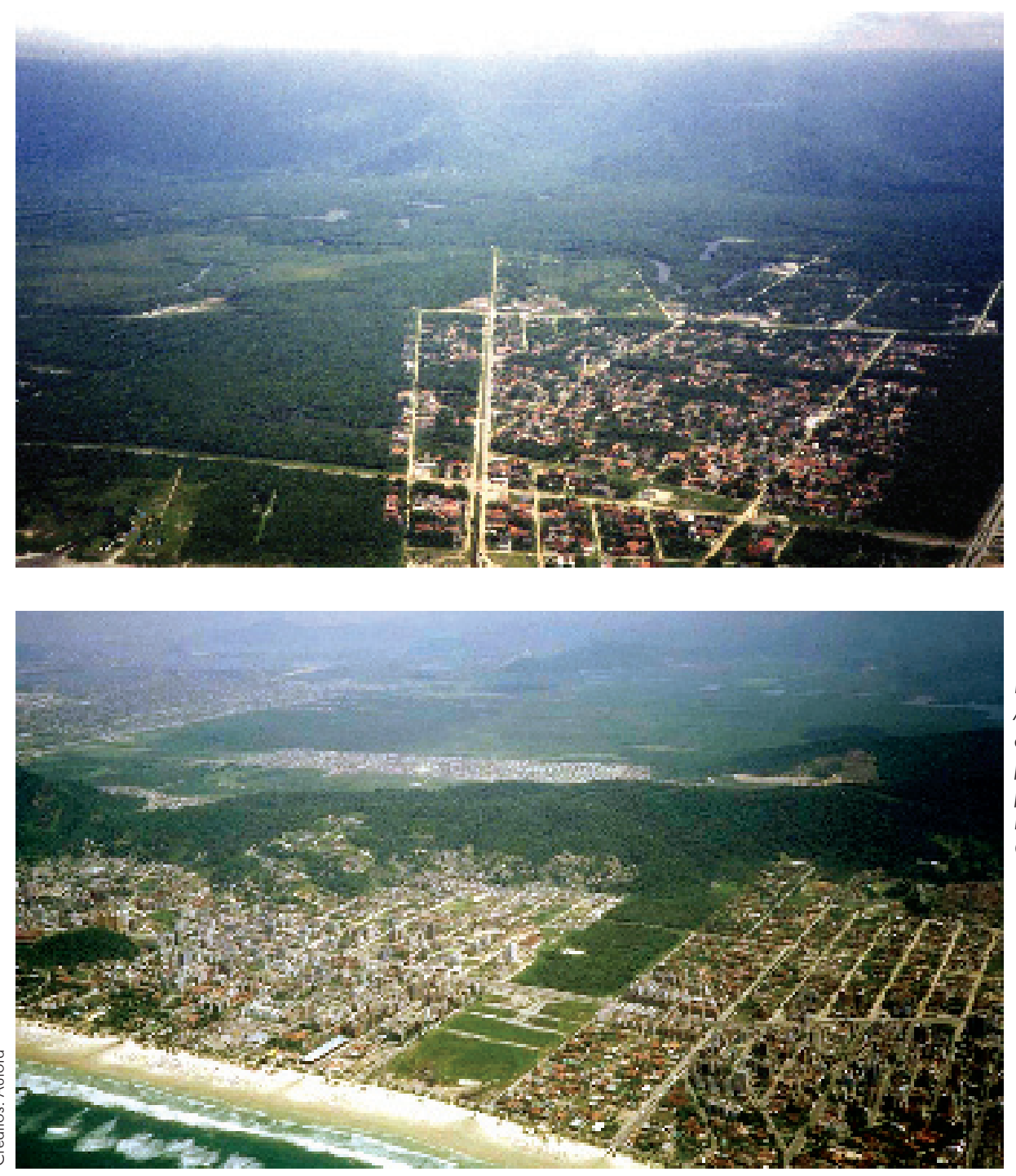

Foto 2:

Áreas planas quase totalmente parceladas na praia da Enseada, município de Guarujá (1998) 
Figura 6 e Foto 3 :

Processo de

verticalização

consolidado na

planície sedimentar

da praia das

Pitangueiras,

município de

Guarujá (1998)
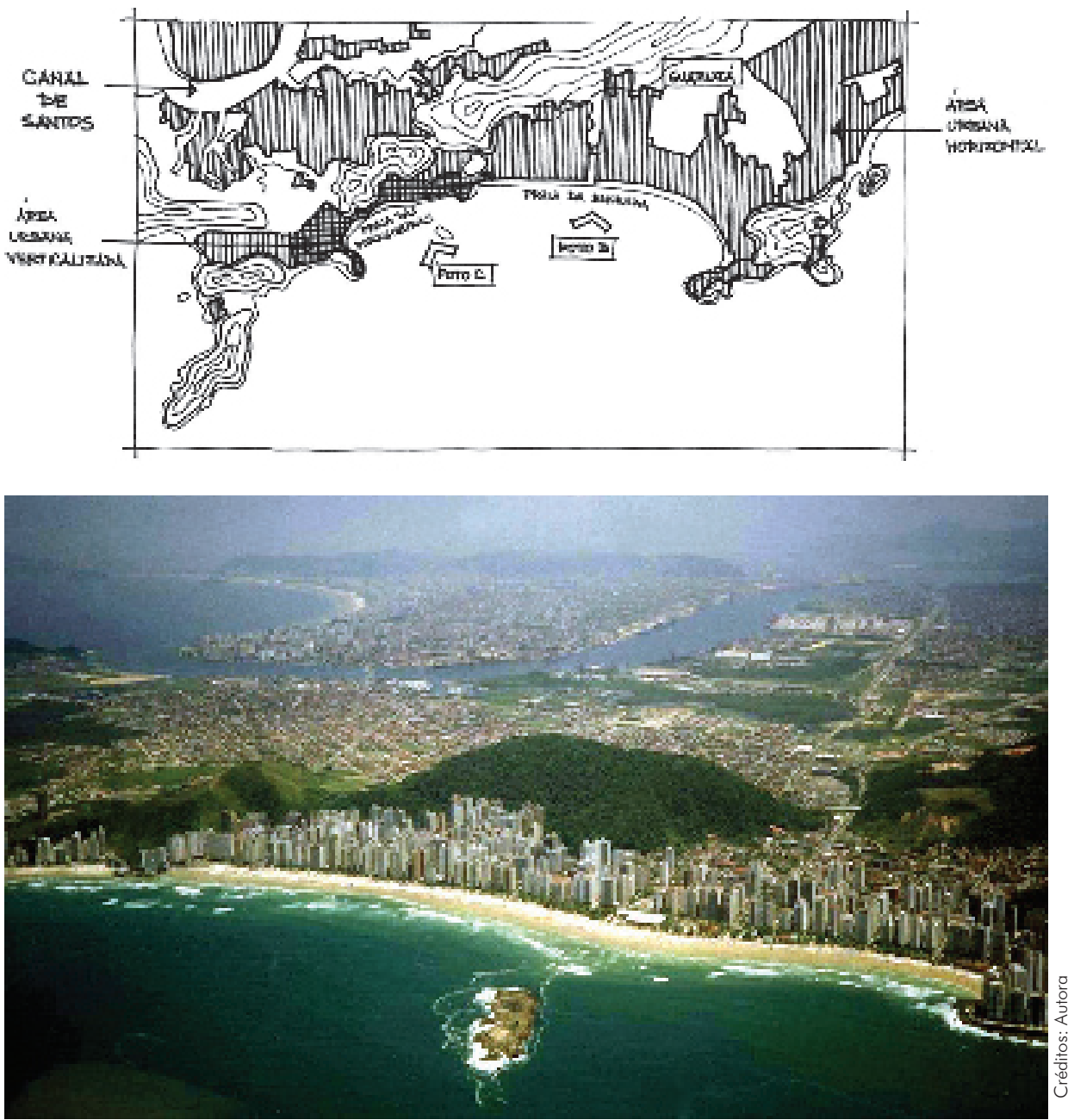

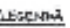

Figura 7:

A área ocupada pelo Complexo

Industrial Naval do

Guarujá (CING)

era, originalmente,

constituída por

manguezais e

pequenos rios

de maré que

desaguavam no

Canal de Santos

(1962)

Fonte: SÃO PAULO,

IGG. Cartas da

região sul do

Brasil: Santos. SÃO

PAULO: IGGSP,

1971

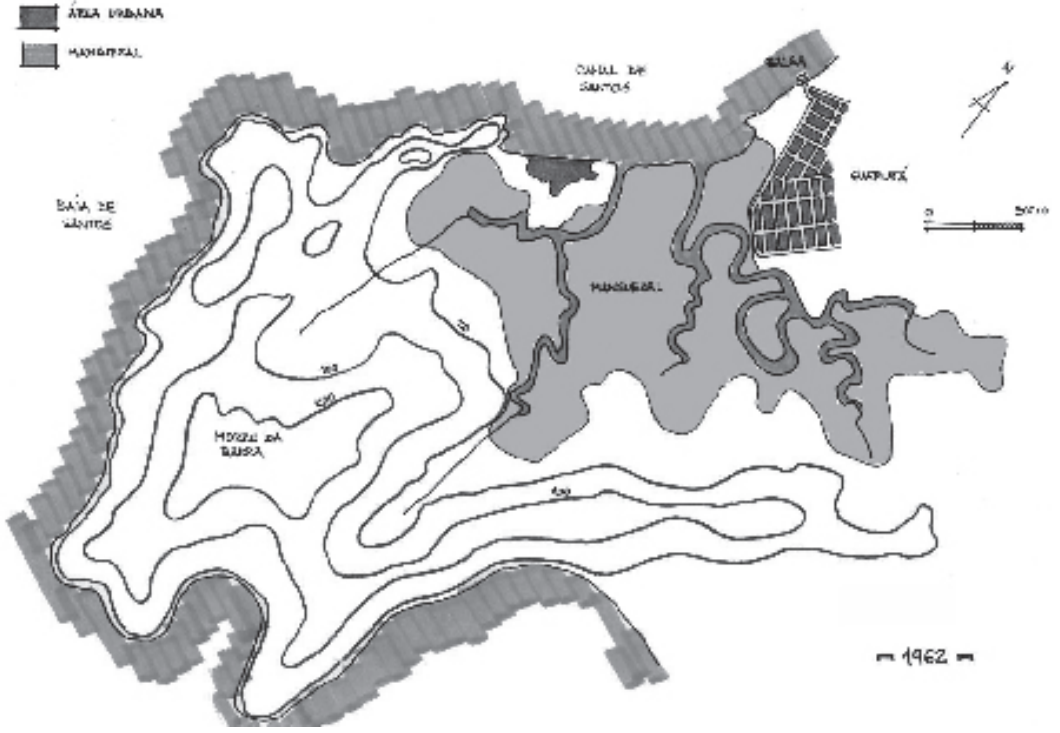


LESENDK

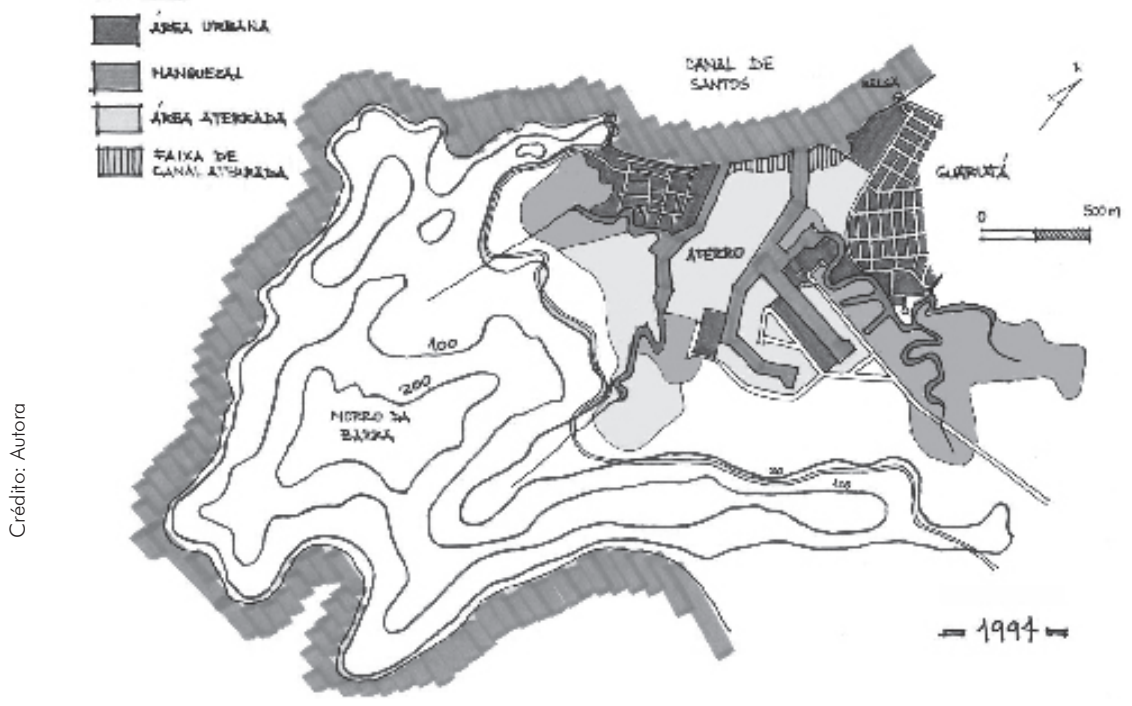

Figura 8 e Foto 4: Manguezais foram aterrados e rios foram retificados para a construção do Complexo Industrial Naval (CING) no município de Guarujá (1994)

Fonte: BASC. Guarujá, P. M. Planta do município do Guarujá, 1994
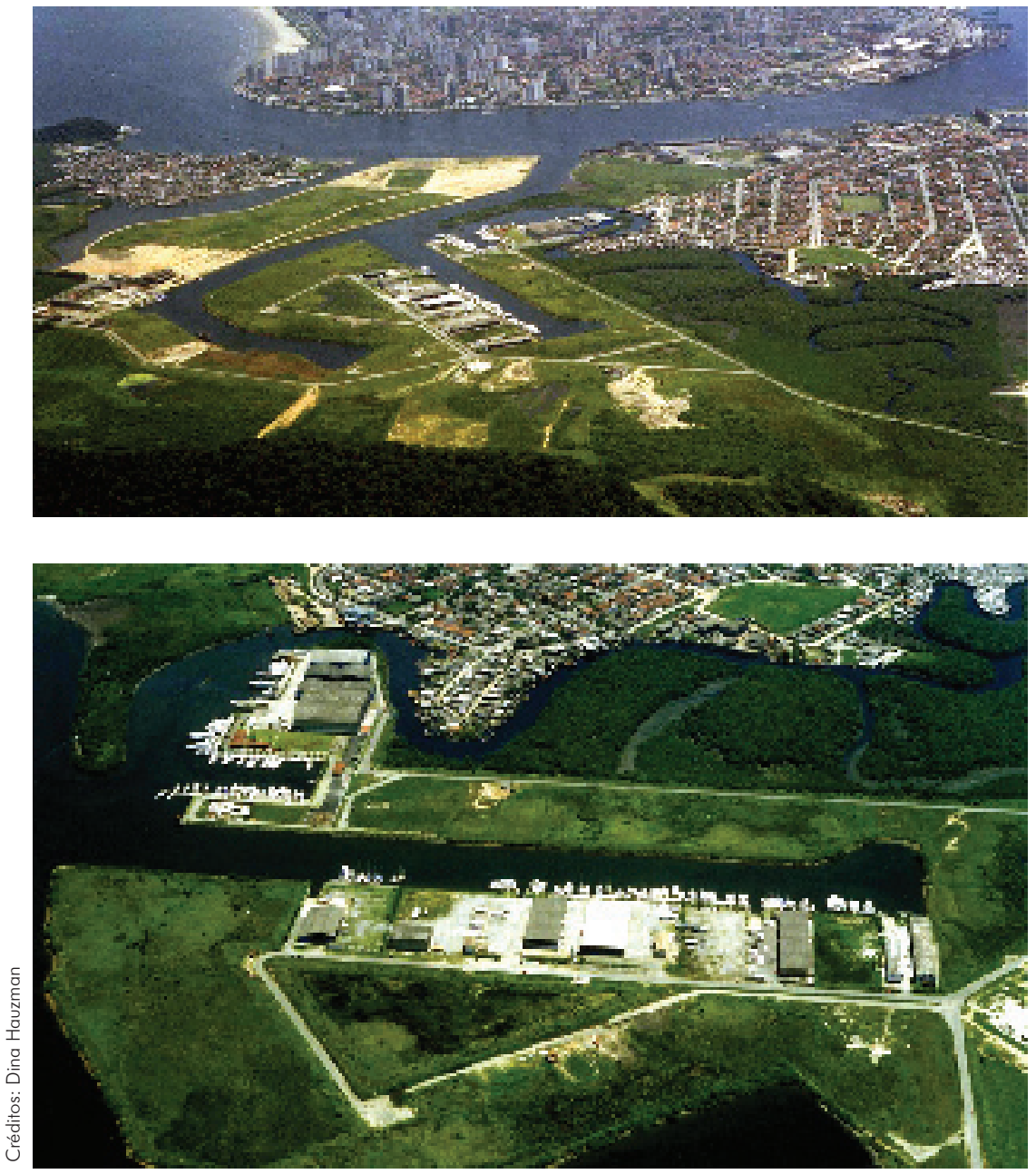

Foto 5:

O Complexo Industrial Naval (CING) é subutilizado e apenas parte de sua área é ocupada por ancoradouros e galpões (Guarujá, 1998) 
No entanto, o recalque do terreno após o aterro (os sedimentos finos e encharcados do manguezal compactam-se, lentamente, com o tempo) e questões judiciais, decorrentes da apropriação privada de área de preservação permanente, têm inviabilizado a utilização do complexo industrial, utilizado apenas parcialmente como atracadouros e oficinas para barcos de lazer.

Também a implantação de edifícios de segunda-residência nos valorizados morros próximos ao mar tem modificado características ambientais e paisagísticas.

Um bom exemplo é o Morro das Astúrias, no Guarujá, no qual a cobertura vegetal e as rochas dos costões, típicos das bordas das enseadas, foram bastante alteradas na face voltada para as praias de Astúrias e Pitangueiras, e os dois pequenos promontórios quase não são mais visíveis.

Foto 6:

A paisagem dos costões foi alterada

e os pequenos promontórios são pouco visíveis no Morro das Astúrias

(Guarujá, 2001)

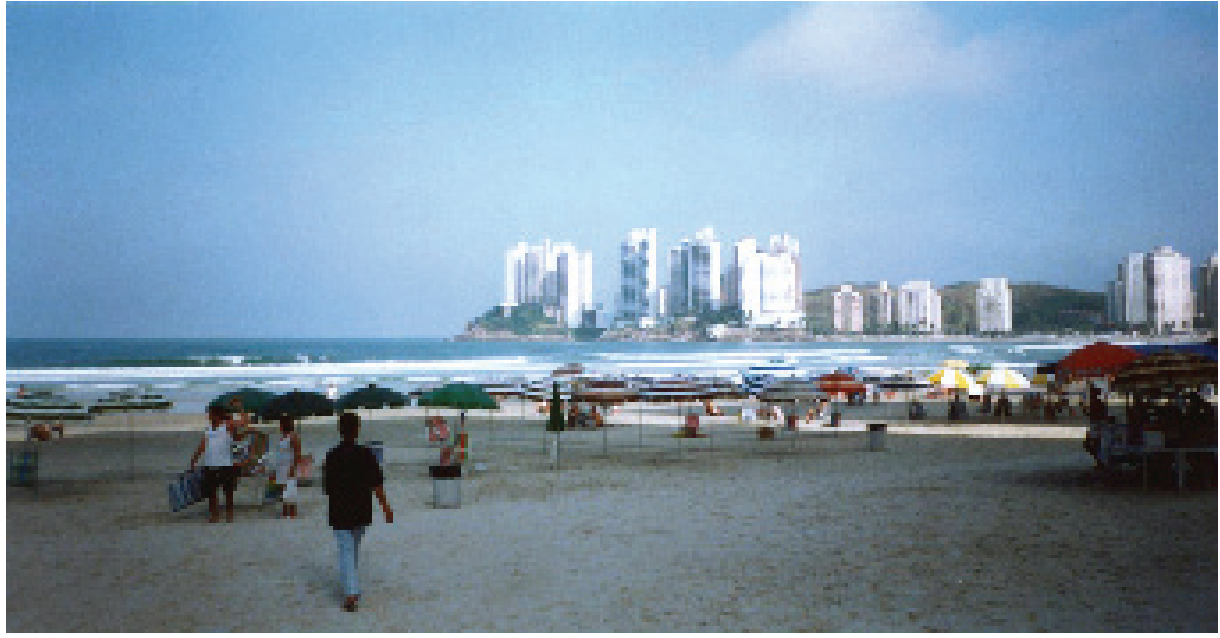

Foto 7 e Figura 9:

Edifícios de

veraneio, com

seus imensos

embasamentos,

configuram uma

nova paisagem no

Morro das Astúrias

(Guarujá, 2001)

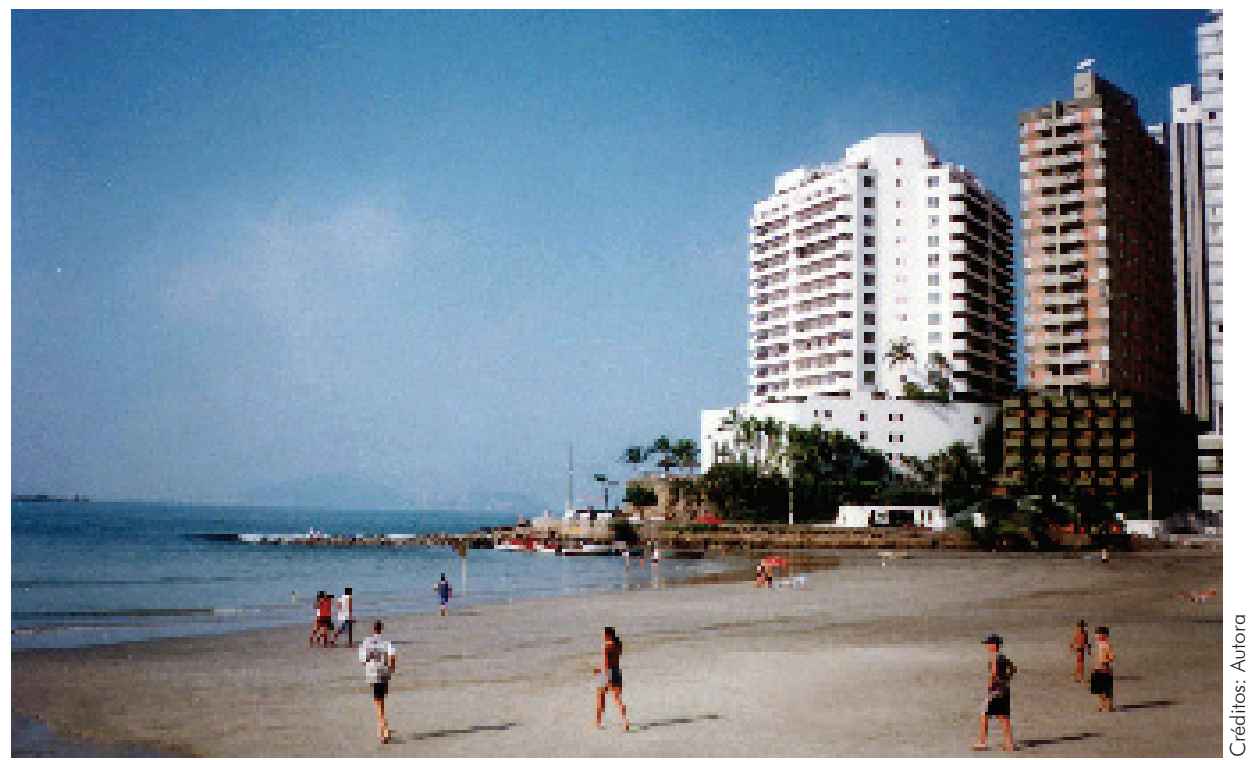




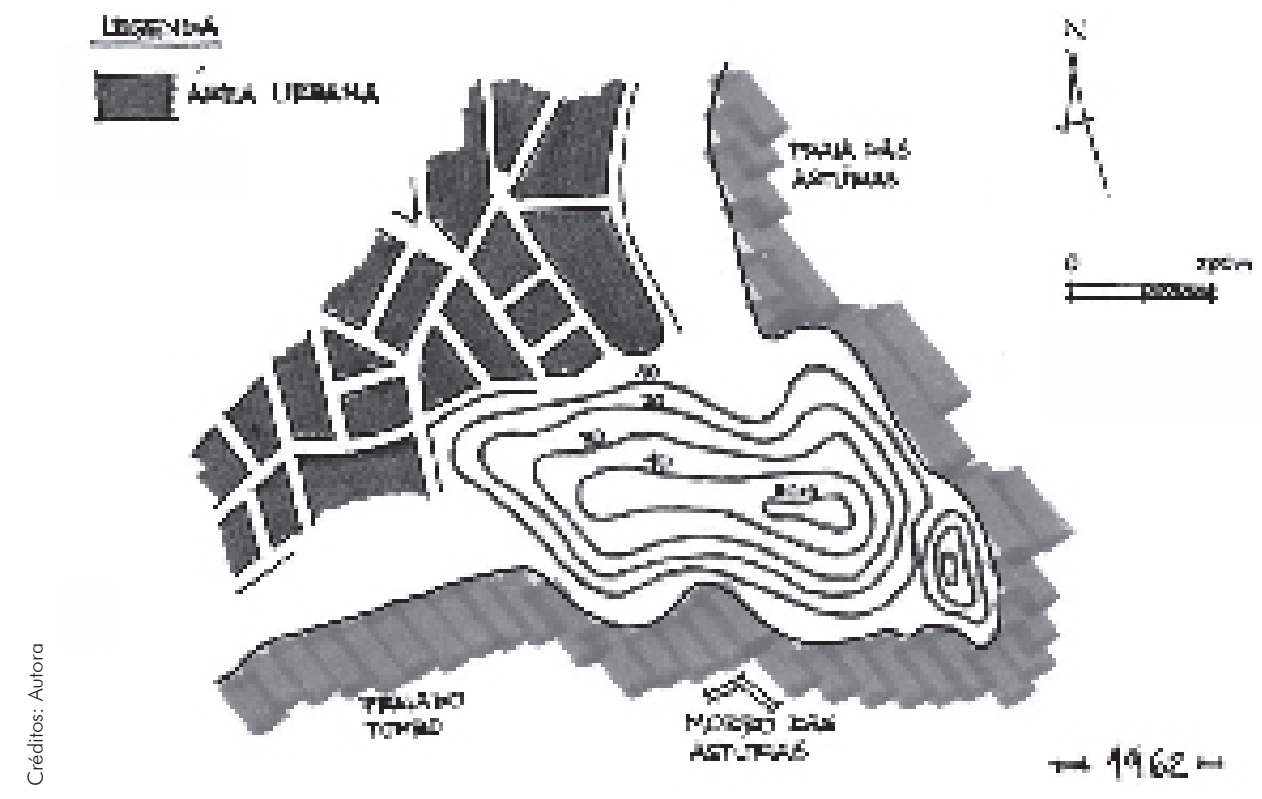

Figura 9:

Morro das Astúrias

em 1962

Fonte: MEDEIROS,

D. B. Guarujá.

In: AZEVEDO, A.

(Org.). A Baixada

Santista: Aspectos

geográficos. São

Paulo: Edusp,

1965

indtring

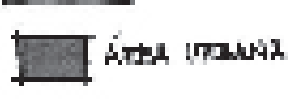

inth IPLAt
Figura 10:

Morro das Astúrias em 1994

Fonte: MEDEIROS;

Base aerofoto-

grametria, 1994.

Guarujá. Planta do

Município, 1994 
Figura 11 :

Morro do Maluf em 1994

Fonte: MEDEIROS, 1965;

Base aerofotogrametria.

Guaruiá. Planta do

Município, 1994

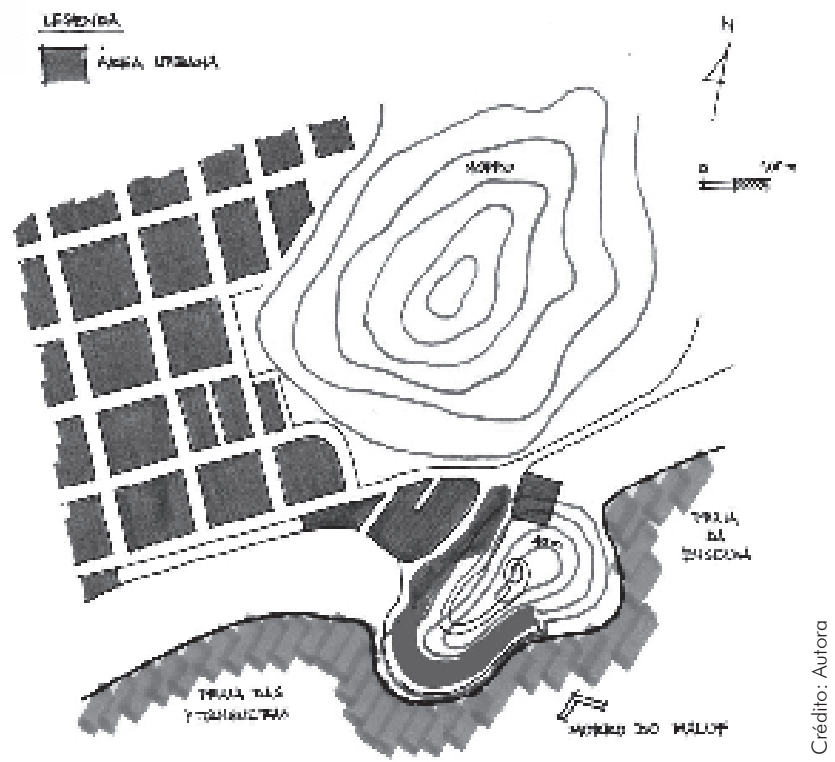

Agora predominam, na paisagem, os altos edifícios debruçados sobre o mar, com seus imensos embasamentos construídos na tentativa de vencer o terreno íngreme e configurar áreas planas aproveitáveis para garagens.

Também no Morro do Maluf, em Guarujá, o aproveitamento das áreas íngremes para a construção de edifícios de veraneio exigiu a modificação das condições topográficas, com a construção de arrimos de concreto para contenção do terreno e execução da via de acesso às edificações, sendo necessários a eliminação da vegetação e o quase soterramento das áreas de costão pelo

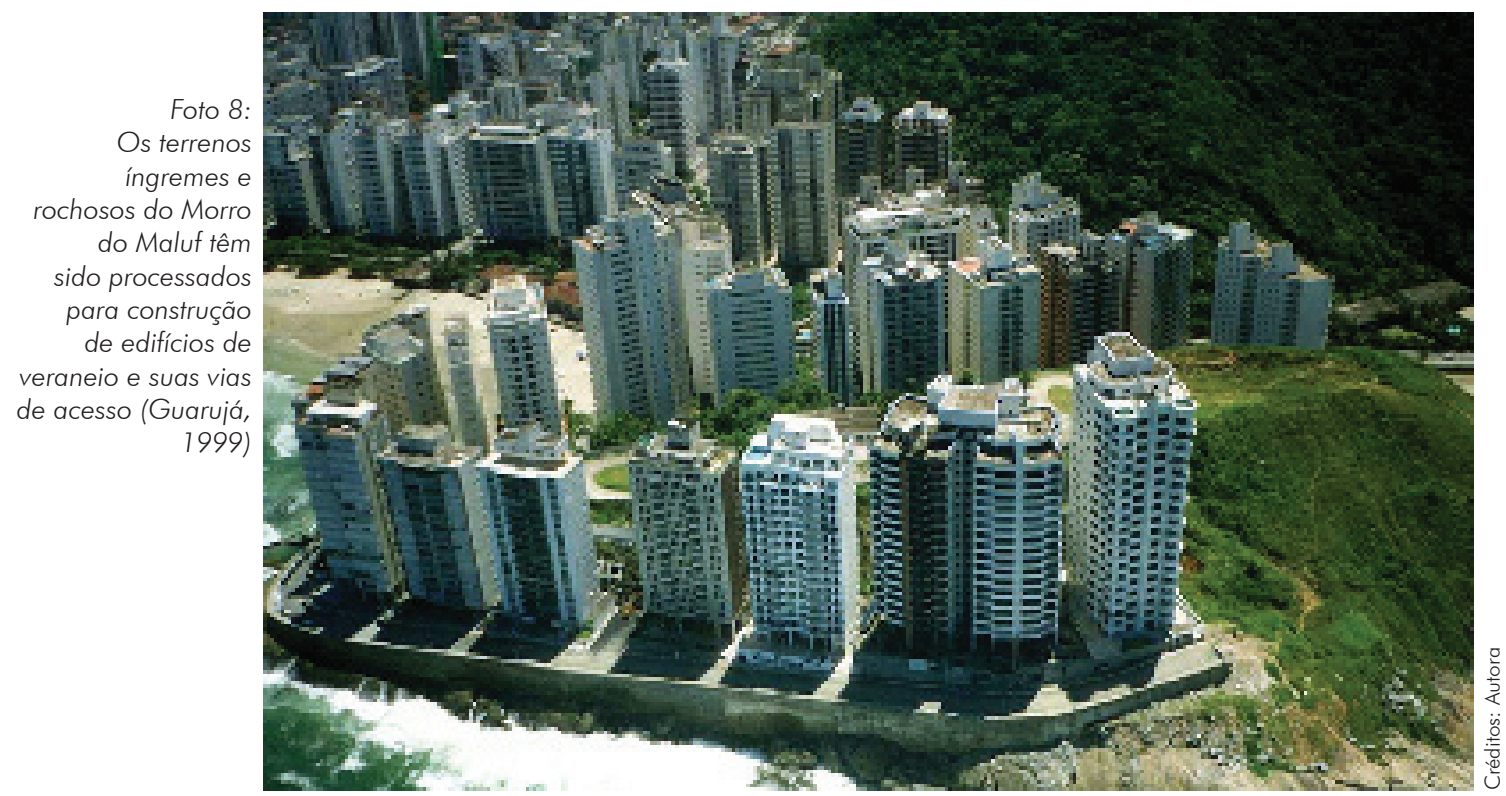


arruamento. Nota-se que no processo de ocupação formou-se uma espécie de coroa de edifícios em volta do morro, buscando aproveitar as áreas mais planas e a vista para o mar.

\section{Padrões Morfológicos Urbanos}

\section{Critérios de Classificação}

Os critérios de classificação da mancha urbana da Baixada Santista são obtidos pela identificação dos padrões morfológicos do tecido urbano na região, em seus aspectos de parcelamento, suporte físico e volumetria (altura e continuidade dos volumes urbanos).

Quanto às formas de parcelamento, a análise das plantas municipais e levantamento aerofotogramétrico permitiu encontrar os seguintes tipos de malha viária:
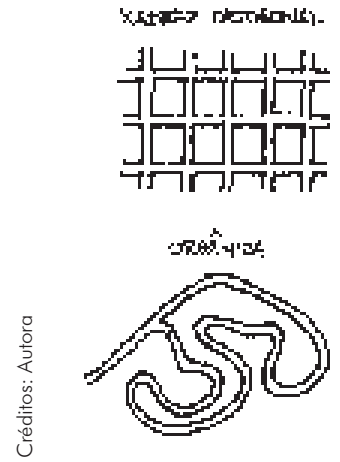

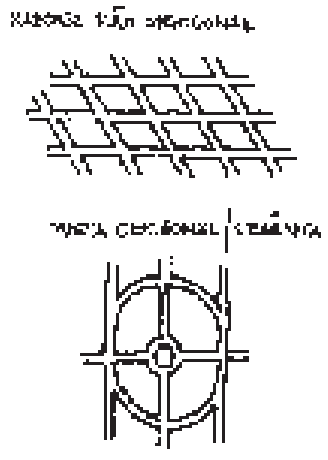

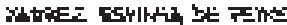

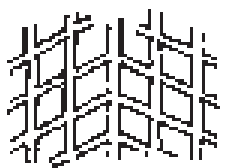

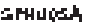

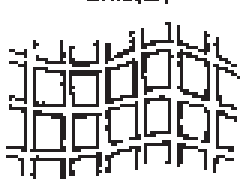

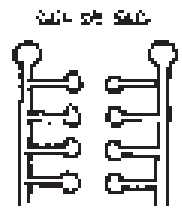

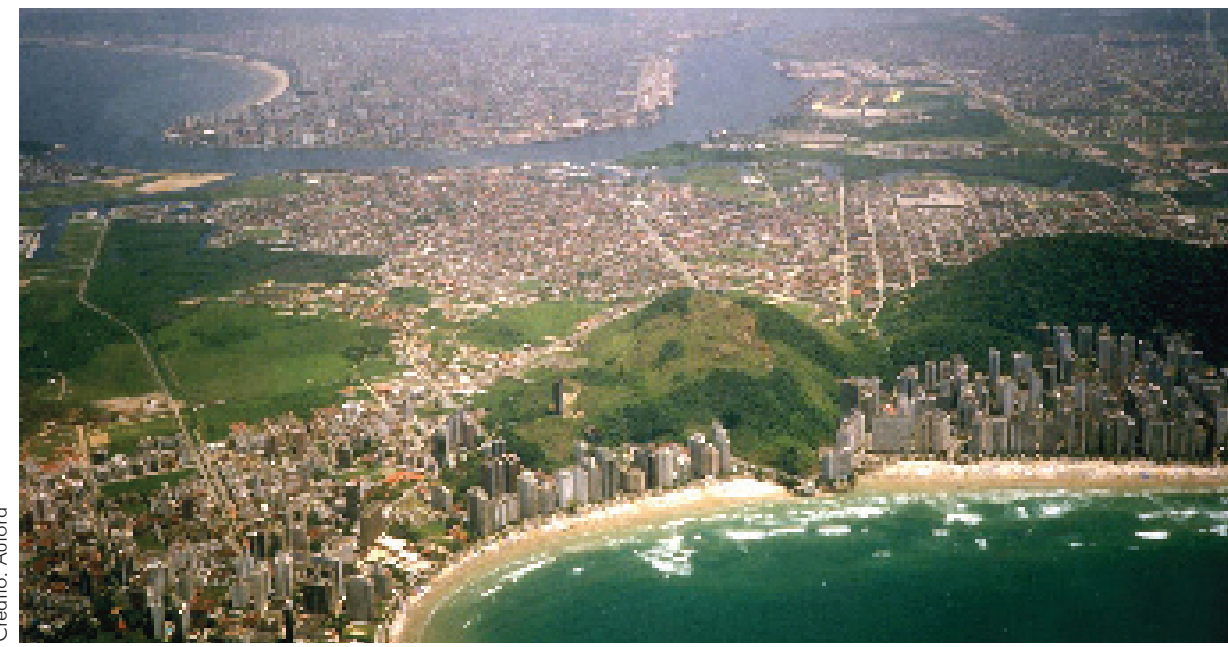

Foto 9

Nos municípios de Guarujá (à frente) e Santos (ao fundo), as áreas verticalizadas se situam junto das praias; os terrenos planos mais interiores são ocupados por urbanização horizontal e os morros e manguezais permanecem, em grande parte, desocupados (1998) 
suporte físico é plano ou íngreme, correspondendo, respectivamente, à planície sedimentar e às áreas serranas ou morros. As áreas planas podem ser subdivididas em inundáveis ou não-inundáveis, de acordo com sua posição em relação ao nível do mar. As terras inundáveis correspondem aos manguezais, periodicamente inundados pelas marés, e as não-inundáveis aos depósitos sedimentares arenosos.

A urbanização tem se localizado, preferencialmente, sobre as áreas planas não-inundáveis, devido às menores dificuldades encontradas para a construção convencional.

Nos municípios de Guarujá (à frente) e Santos (ao fundo), as áreas verticalizadas se situam nas praias, os terrenos planos mais interiores são ocupados por urbanização horizontal e os morros e manguezais permanecem, em grande parte, desocupados (1998).

Quanto à continuidade/contigüidade dos volumes construídos e plantados, foram identificadas as seguintes tipologias:

- edificações próximas, com escassez de vegetação

Fotol0 e Figura 13: Área de expansão urbana no município de Praia Grande (1998)
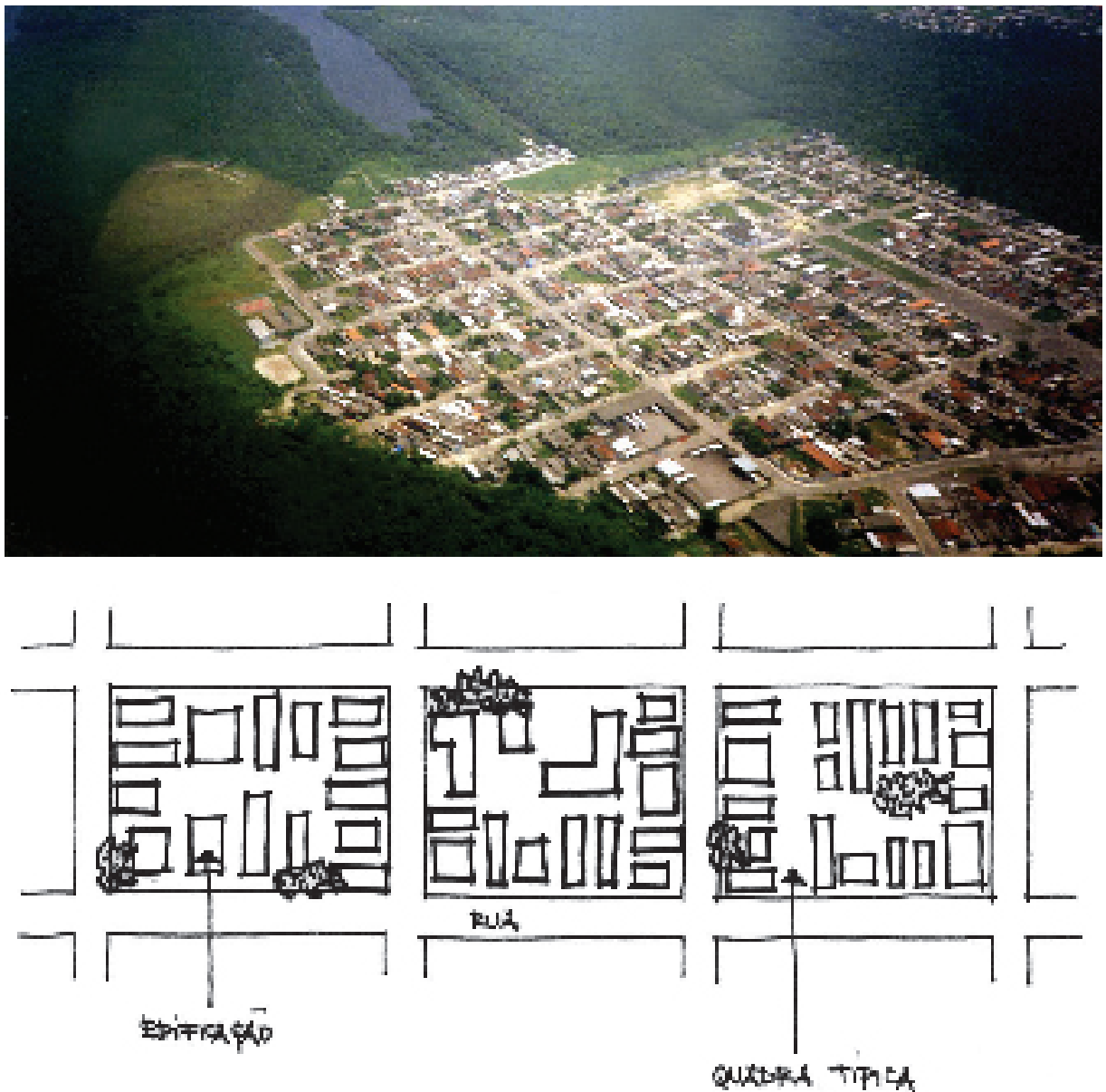


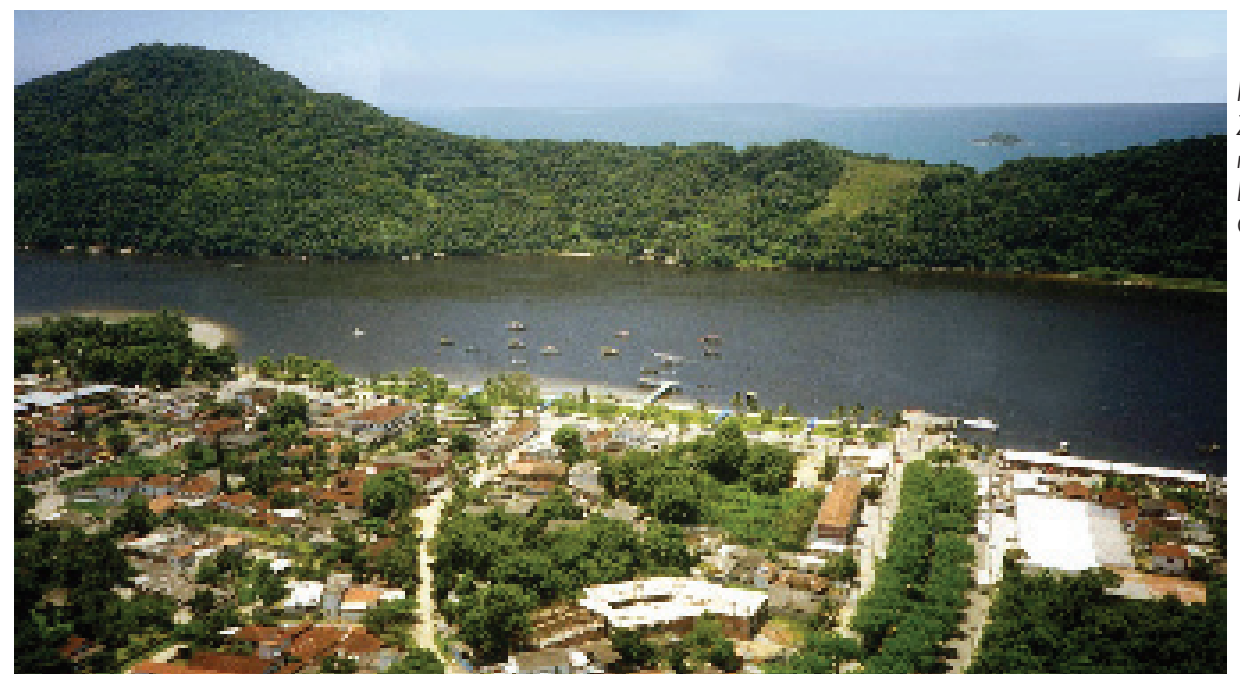

Foto 17 :

Zona central do município de

Bertioga, situada no

Canal (1998)

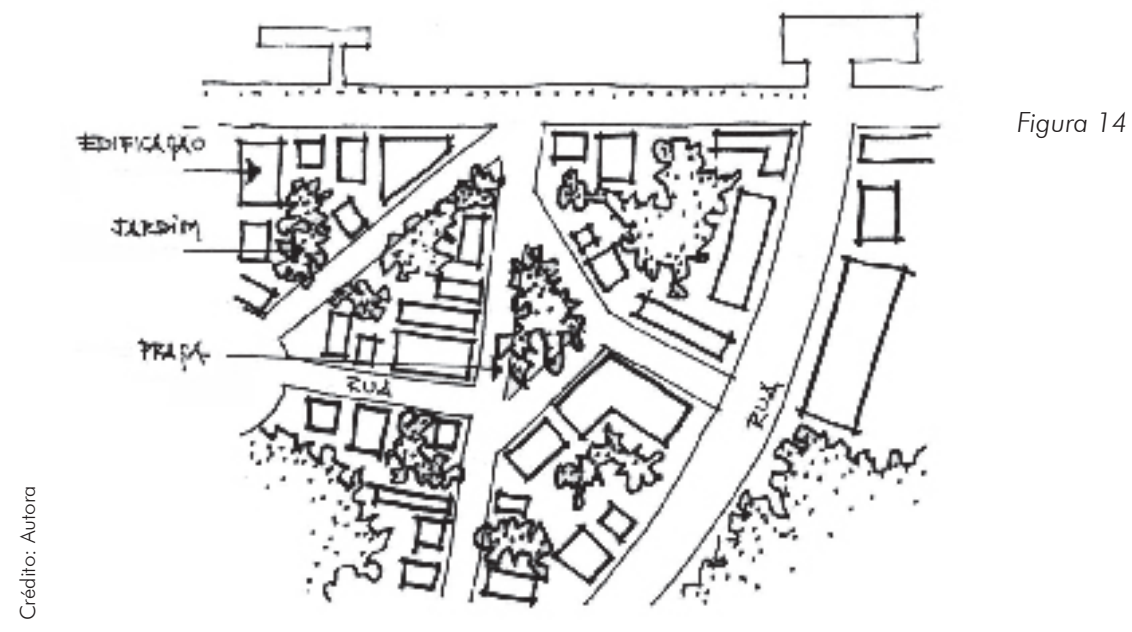

- edificações espalhadas em meio à vegetação natural

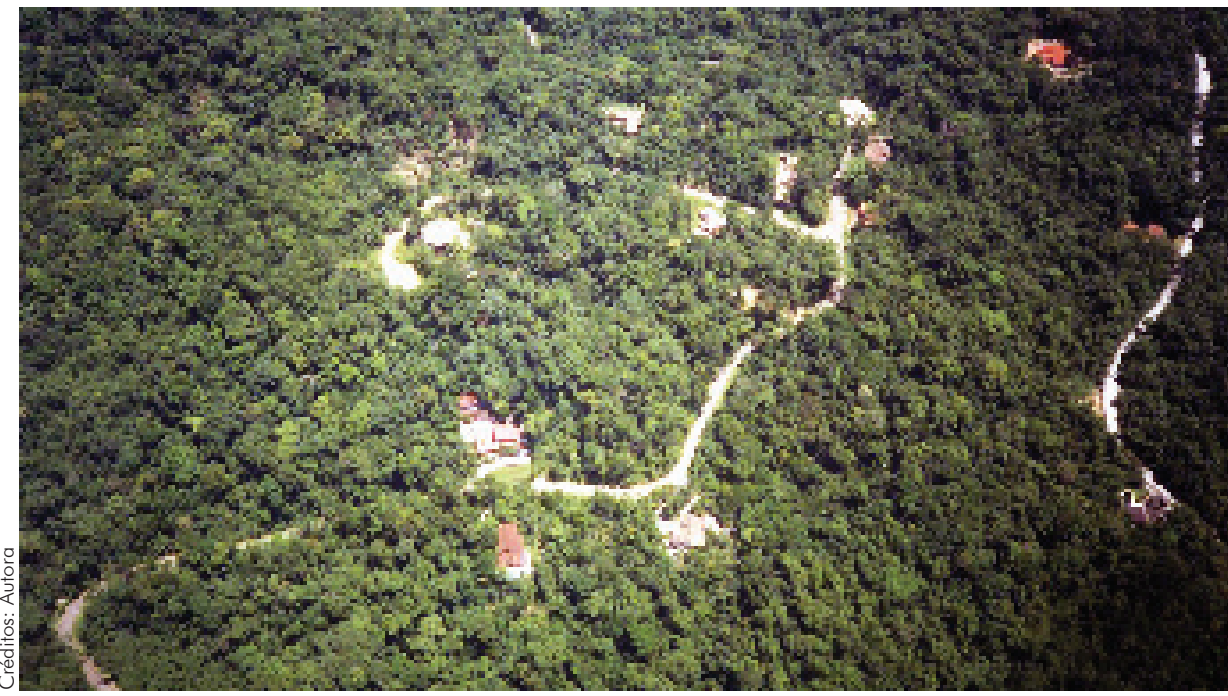

Foto 12:

Condomínio de

alto luxo com

residências de

veraneio na praia

de lporanga,

município de

Guarujá (1998) 
Figura 15

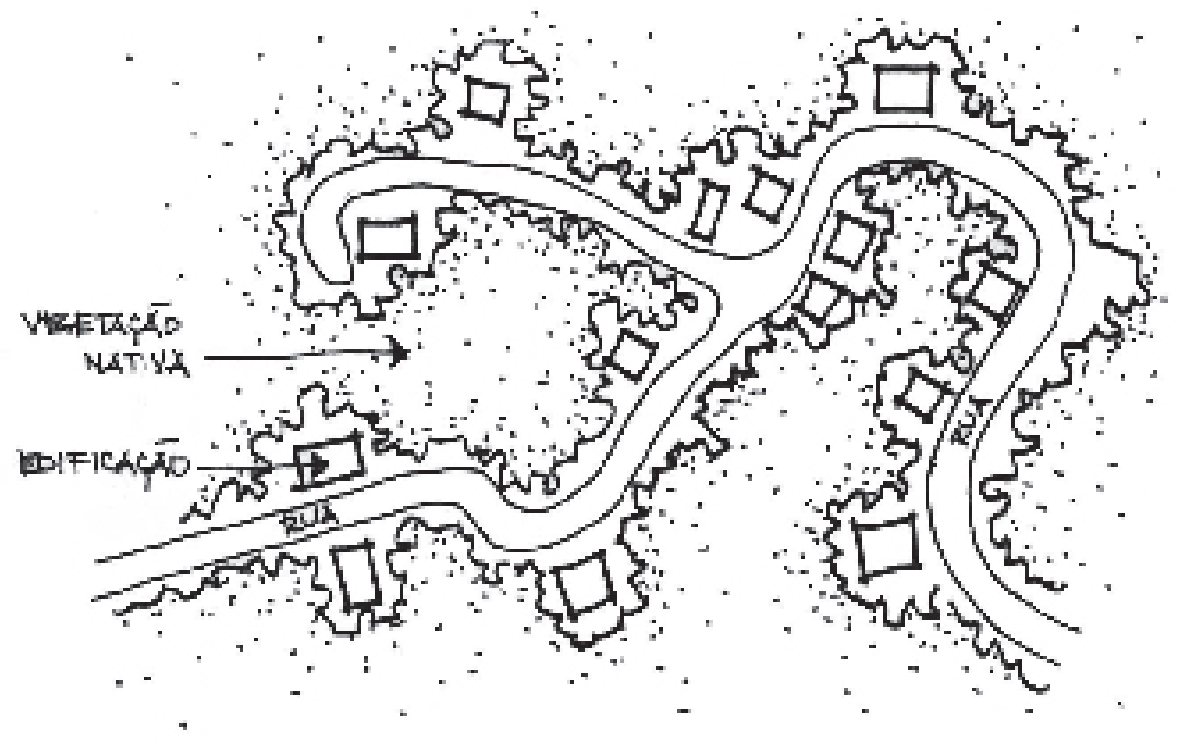

- edificações relativamente afastadas em meio a jardins

Os espaços livres internos às áreas urbanas, geralmente, limitam-se às ruas e calçadas, sendo escassas as praças e parques. Nesse quadro, as praias desempenham importante papel como áreas de lazer, colocando-se como grandes parques lineares margeados por calçadões e jardins.

Foto 13:

Orla litorânea no município de Praia

Grande (1998)

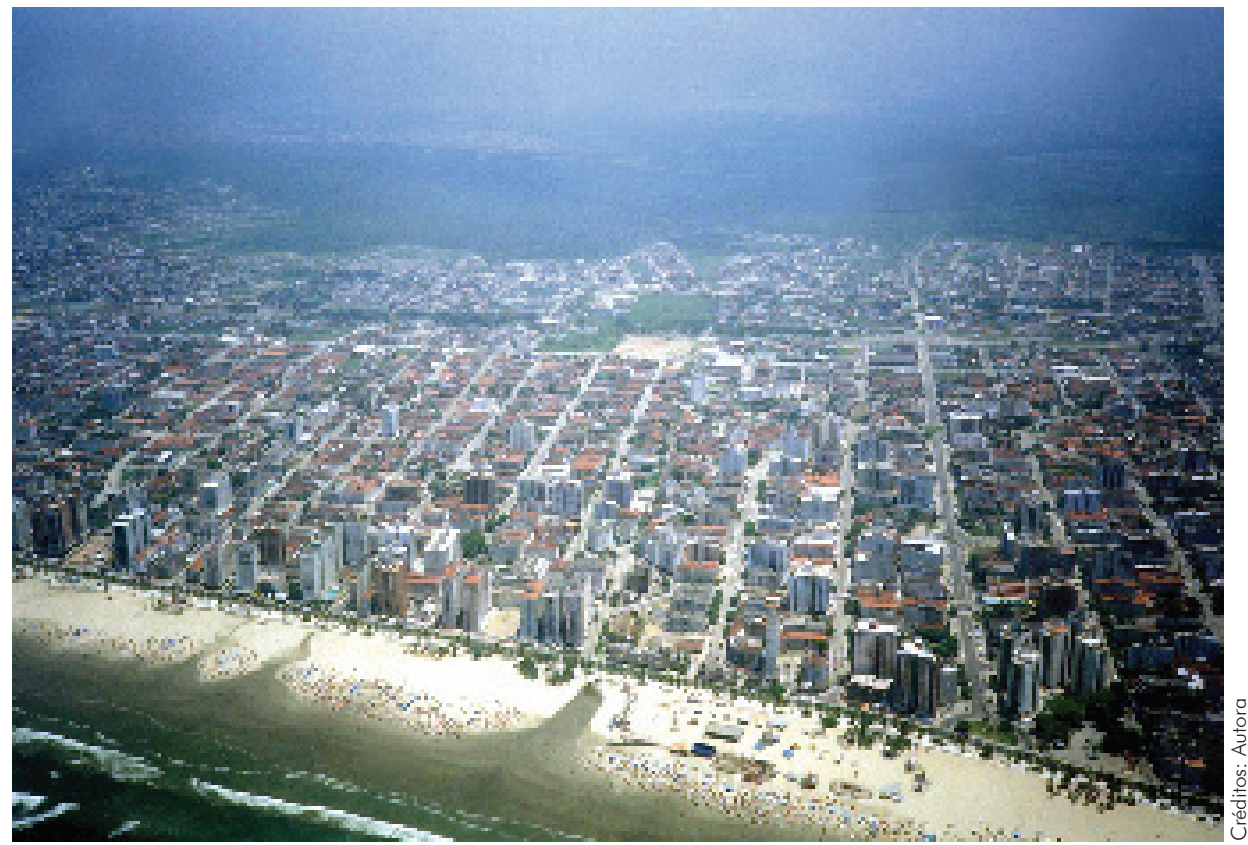




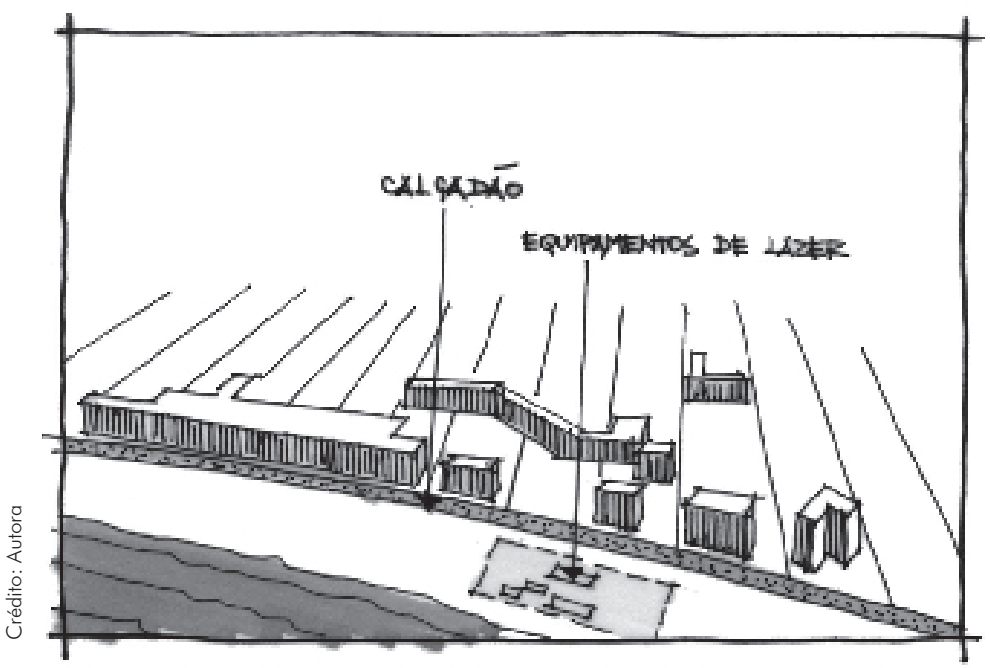

Figura 16

\section{Padrões Morfológicos da Área Urbana²}

Dentro das áreas classificadas como urbanas identificam-se três padrões morfológicos distintos:

- Área urbana horizontal;

- área urbana verticalizada;

- área urbana horizontal com predomínio de vegetação.

A área urbana horizontal apresenta como características principais a proximidade entre as edificações e a escassez de vegetação, estando assentada, preferencialmente, sobre as áreas planas não-inundáveis. Diversas formas de parcelamento do solo se encontram e mesclam-se, dando a impressão de uma colcha de retalhos, sendo encontradas malhas viárias do tipo xadrez ortogonal, xadrez não-ortogonal, sinuosa e mista ortogonal/orgânica.

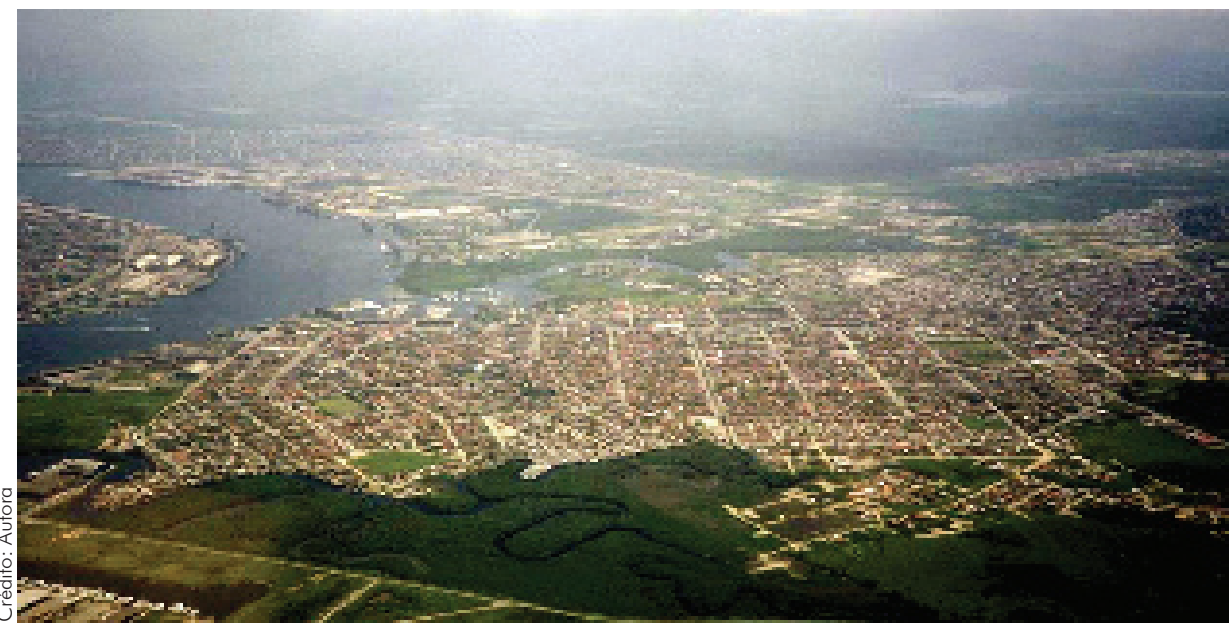

Foto 14: Área urbana horizontal no município de Guarujá, próxima à balsa para Santos (1998)

(2) Entende-se por área urbana a área ocupada por urbanização em mancha contínua, com funções urbanas consolidadas. 
Os bairros-jardins, com edificações de alto padrão em meio a áreas ajardinadas, sobre malha viária sinuosa ou ortogonal, apresentam-se como exceções à área urbana horizontal típica, ocorrendo, preferencialmente, nas proximidades das praias freqüentadas pelas camadas populacionais mais abastadas.

Foto 15: Área urbana, predominantemente turística, na praia da Enseada, município de Bertioga (1998)

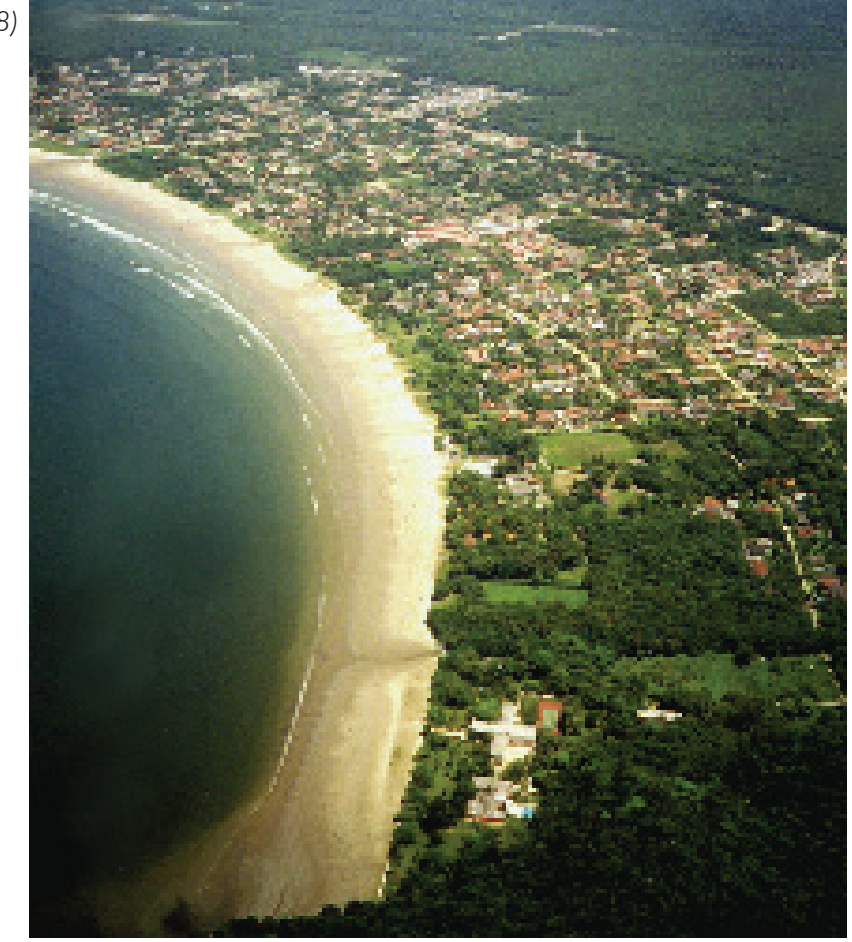

A área urbana verticalizada típica, encontrada, principalmente, na faixa próxima à orla litorânea, é decorrente do adensamento da área urbana horizontal preexistente, sem que ocorram alterações na malha viária, na escassez de vegetação ou na proximidade das edificações. Também são encontradas, em número reduzido, áreas verticalizadas compostas por edificações distribuídas sobre gleba não-loteada, nos poucos conjuntos habitacionais verticalizados ou em condomínios de alto padrão, com edifícios em meio a áreas ajardinadas.

Foto 16:

Verticalização na praia sobre malha viária preexistente na praia das Pitangueiras, município de Guarujá (1998)

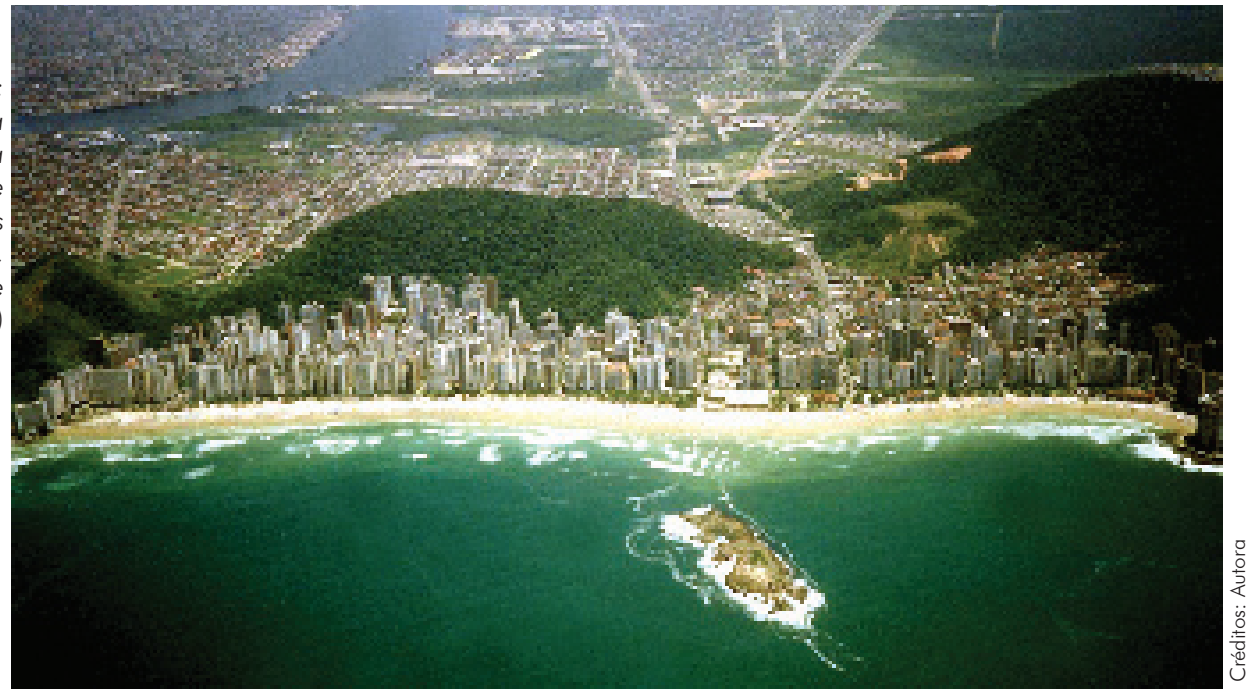




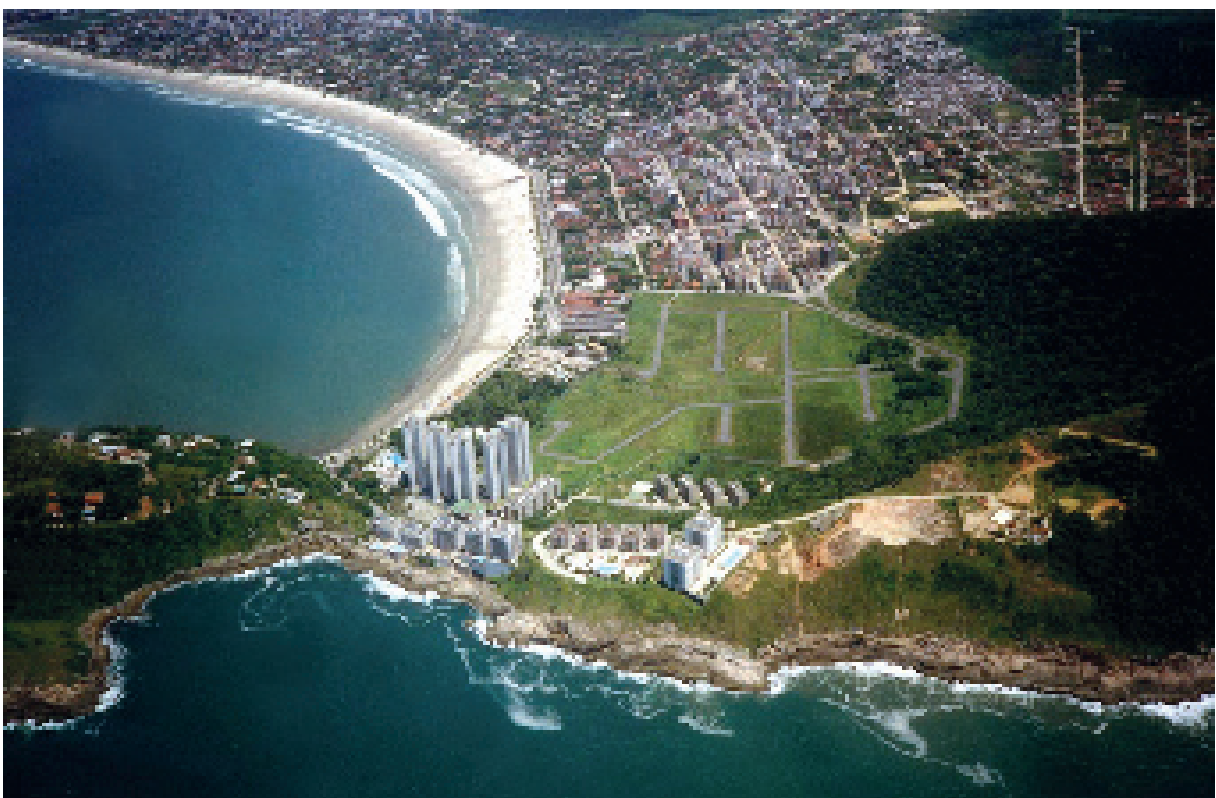

Foto 17:

Verticalização sobre gleba nãoloteada próxima ao mar, no Costão das Tartarugas, município de Guarujá (1998)

Foto 18

Residências de veraneio em meio à vegetação na Ponta de Santo Amaro, praia da Enseada, município de Guaruiá (1998)

is क 50 5. E ह ? 3.
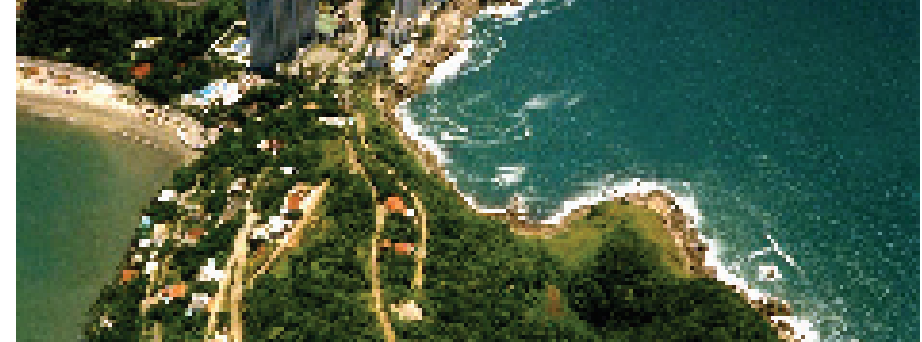
A área urbana com predomínio de vegetação é encontrada nos condomínios fechados ou em loteamentos turísticos de alto padrão, apresentando como características as edificações espalhadas no meio da vegetação nativa ou de grandes jardins, assentadas sobre malha viária orgânica desenhada nas encostas dos morros próximos ao mar. As edificações são, geralmente, constituídas por residências unifamiliares isoladas, sendo raros os casos de construção de edifícios com vários pavimentos em meio à vegetação.

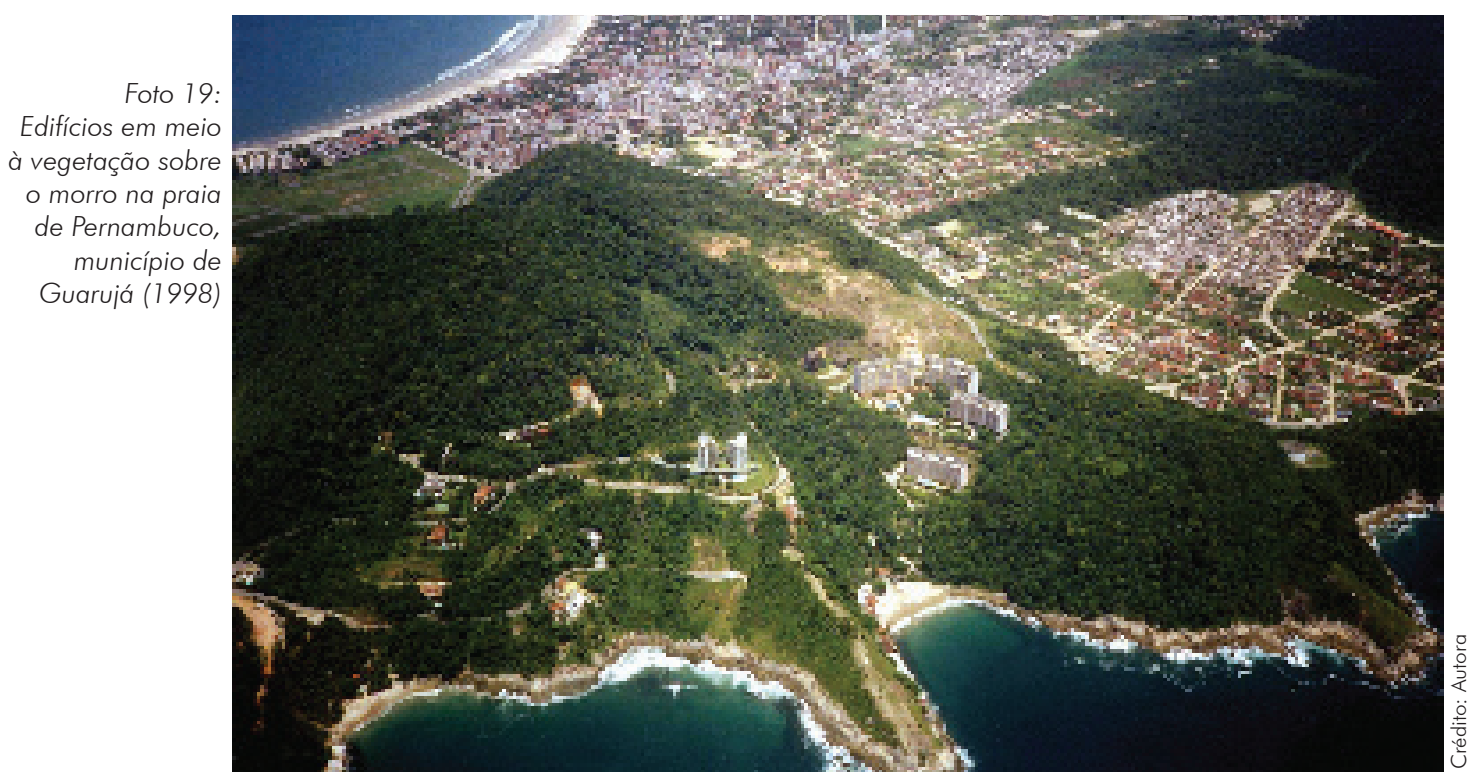

\section{Padrões Morfológicos da Área de Expansão Urbana ${ }^{3}$}

Nas áreas classificadas como de expansão urbana também se identificam três padrões morfológicos distintos:

- área de expansão urbana loteada;

- área de expansão urbana loteada sem ocupação ou com ocupação esparsa;

- área de expansão urbana não-loteada.

As áreas de expansão urbana loteada apresentam características similares às áreas urbanas horizontais consolidadas, com proximidade entre edificações, escassez de vegetação e preferência por áreas planas não-inundáveis, diferenciando-se devido à descontinuidade de ocorrência dentro da mancha urbana. Nestas manchas isoladas também se verifica a presença de diversos tipos de malha viária, incluindo as do tipo xadrez ortogonal e não-ortogonal, mista ortogonal/orgânica e xadrez do tipo espinha de peixe, típicas de conjuntos habitacionais horizontais.

(3) Entende-se por área de expansão urbana a área em processo de consolidação, que apresenta mancha descontínua e ocupação incompleta ou rarefeita. 


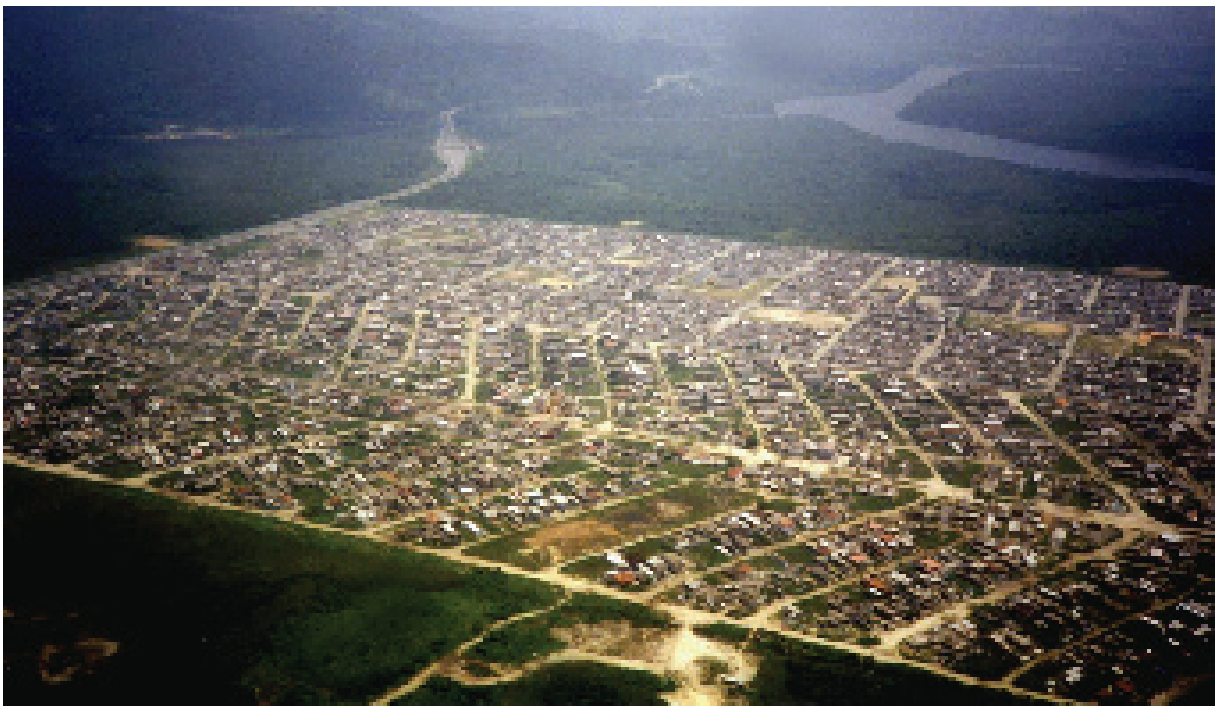

Foto 20:

Área de expansão urbana loteada: conjuntos habitacionais populares, situados próximos à rodovia Padre Manoel da Nóbrega, município de São Vicente (1998)

Essa descontinuidade também é elemento definidor das áreas loteadas sem ocupação ou com ocupação esparsa, que apresentam, além da descontinuidade de ocorrência na mancha urbana, descontinuidade na presença dos volumes construídos. Constituem as frentes de expansão urbana mais recentes, tendo como característica a presença de poucas edificações horizontais espalhadas por quadras quase vazias, muitas vezes desprovidas de vegetação. A forma de parcelamento do solo é variável, tendo sido encontradas malhas viárias do tipo xadrez não-ortogonal, mista ortogonal/orgânica e cul-de-sac (nos loteamentos de alto padrão), muitas vezes diferentes das existentes nas áreas urbanas a que são contíguas.

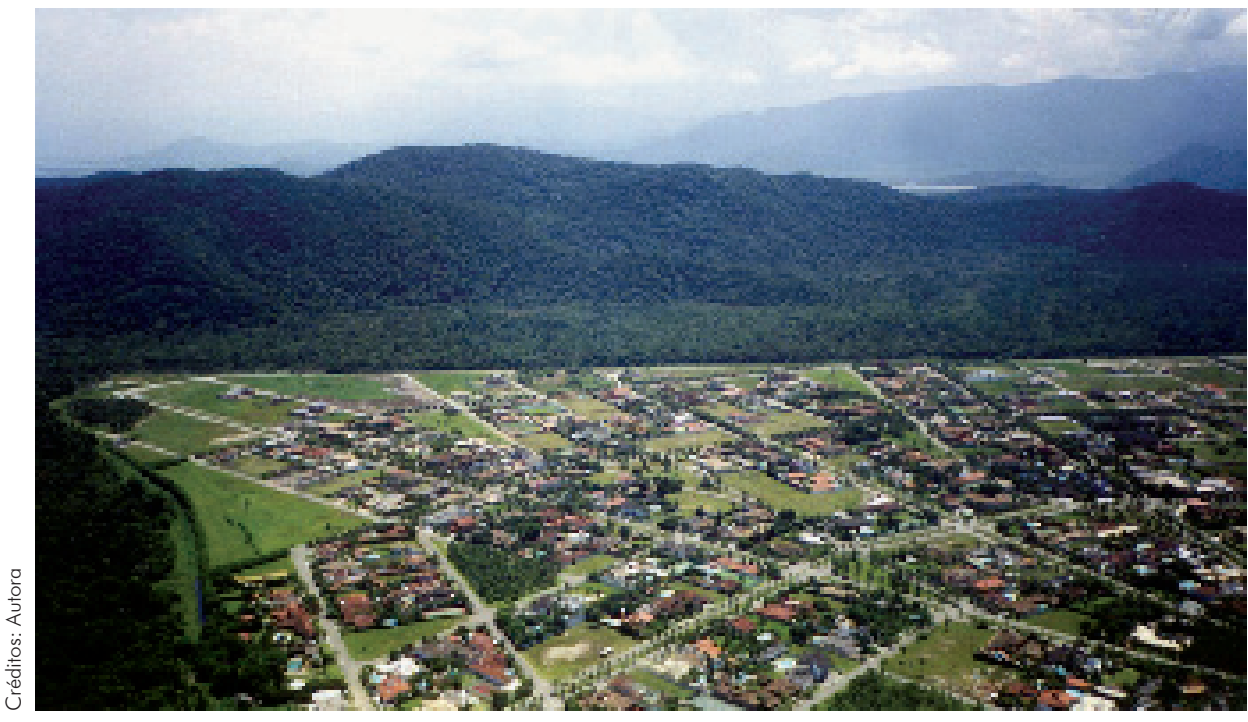

Foto 21:

Área de ocupação esparsa nas bordas do loteamento Jardim Acapulco, na praia de Pernambuco, município de Guarujá (1999)

As áreas de expansão urbana não-loteada ocorrem sobre as terras inaproveitadas pela ocupação urbana formal. São áreas íngremes como as encostas da Serra do Mar e morros da llha de São Vicente ou áreas inundáveis como 
os manguezais, e constituem terras de domínio público invadidas pela população de baixo poder aquisitivo.

Apresentam como características marcantes a ausência de arruamento definido, sendo encontradas apenas algumas ruas principais não-asfaltadas de acesso ao bairro, e a grande proximidade entre edificações de pequenas dimensões. Apesar da proximidade da mata atlântica ou dos mangues, é muito pequena a quantidade de árvores existentes entre as edificações, sendo, geralmente, eliminada a cobertura vegetal preexistente.

Foto 22: Área de manguezal ocupada por população de baixa renda, situada próxima às rodovias Padre Manoel da Nóbrega e Imigrantes, no município de Cubatão (1998)

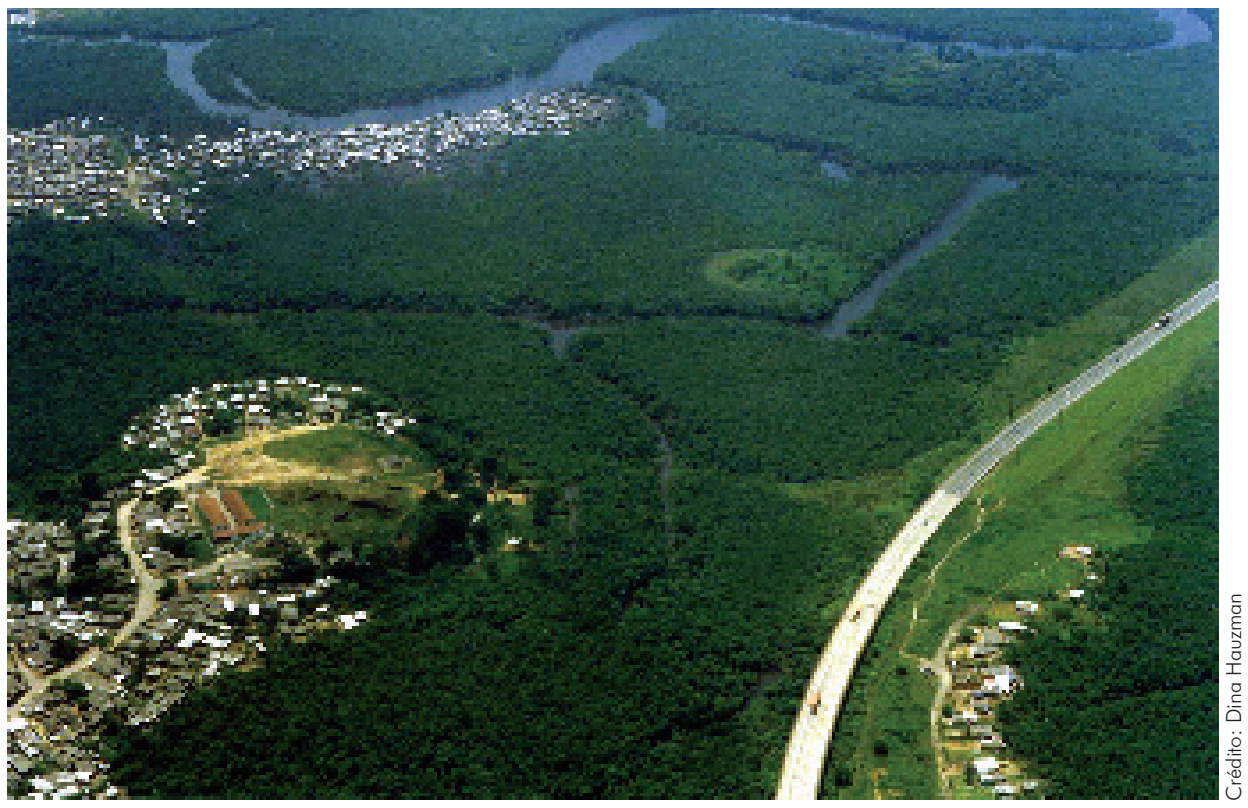

\section{Padrões Morfológicos Específicos}

Verifica-se a presença de atividades urbanas com morfologias contrastantes no tecido urbano e, portanto, classificadas segundo categorias específicas. São elas: indústrias, instalações náuticas, clubes e porto.

As indústrias se destacam pela ocupação de grandes glebas, presença de edificações de grandes dimensões, uso das áreas livres entre os edifícios para atividades industriais externas e pouca ou nenhuma presença de vegetação.

As instalações náuticas, mais especificamente os iate clubes e marinas ligados ao lazer náutico, caracterizam-se pela ocupação de áreas próximas aos canais estuarinos, muitas vezes modificando seus limites por meio de dragagem de canais para ancoragem das embarcações. Em geral se limitam à guarda de barcos, mas podem assumir maiores proporções ao incluir a construção de residências com ancoradouros individuais à margem dos canais dragados. 


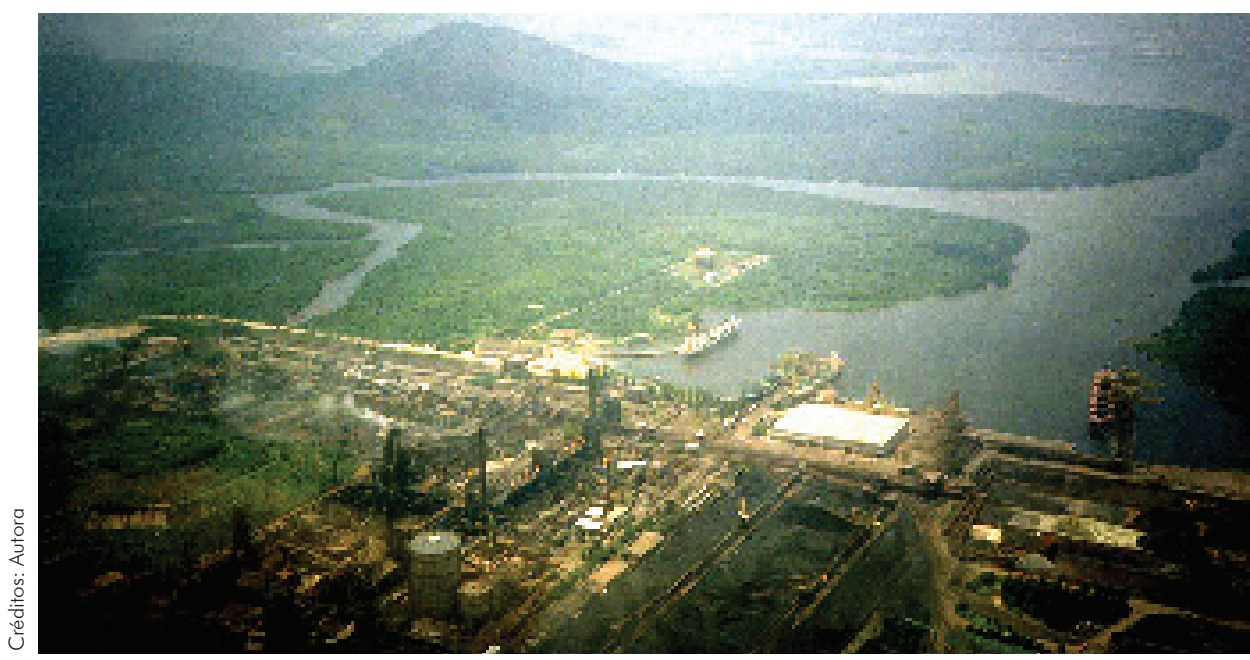

Foto 23:

Companhia

Siderúrgica Paulista,

município de

Cubatão (1998)

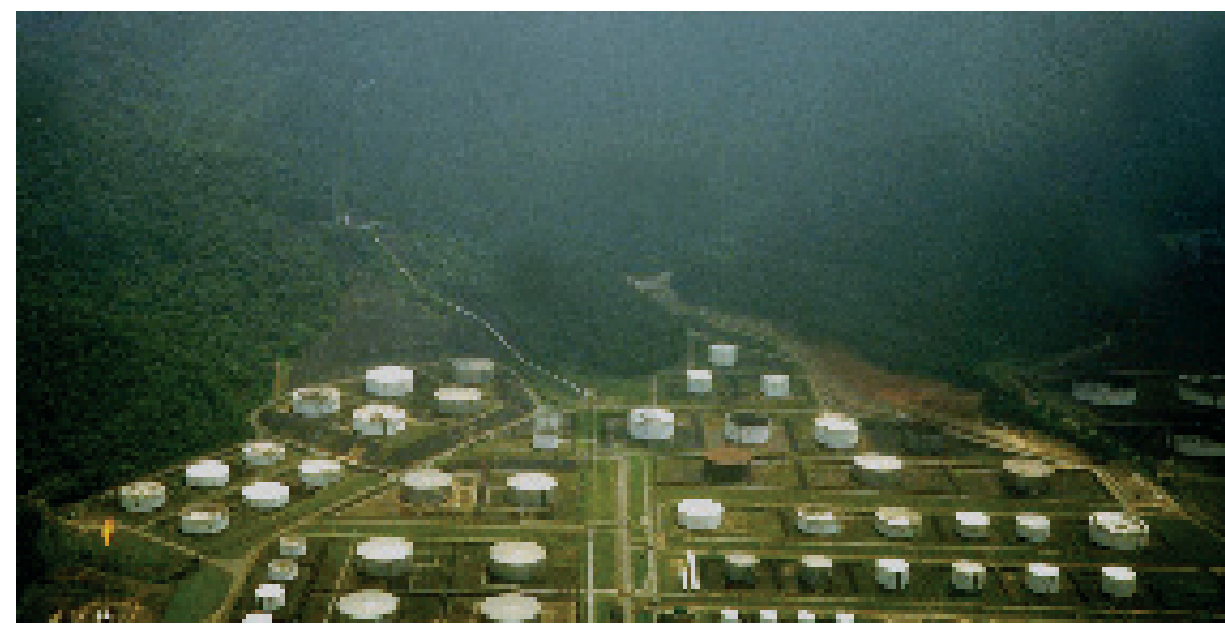

Foto 24:

Refinaria de

petróleo Presidente

Bernardes, da

Petrobrás, município

de Cubatão (1998)

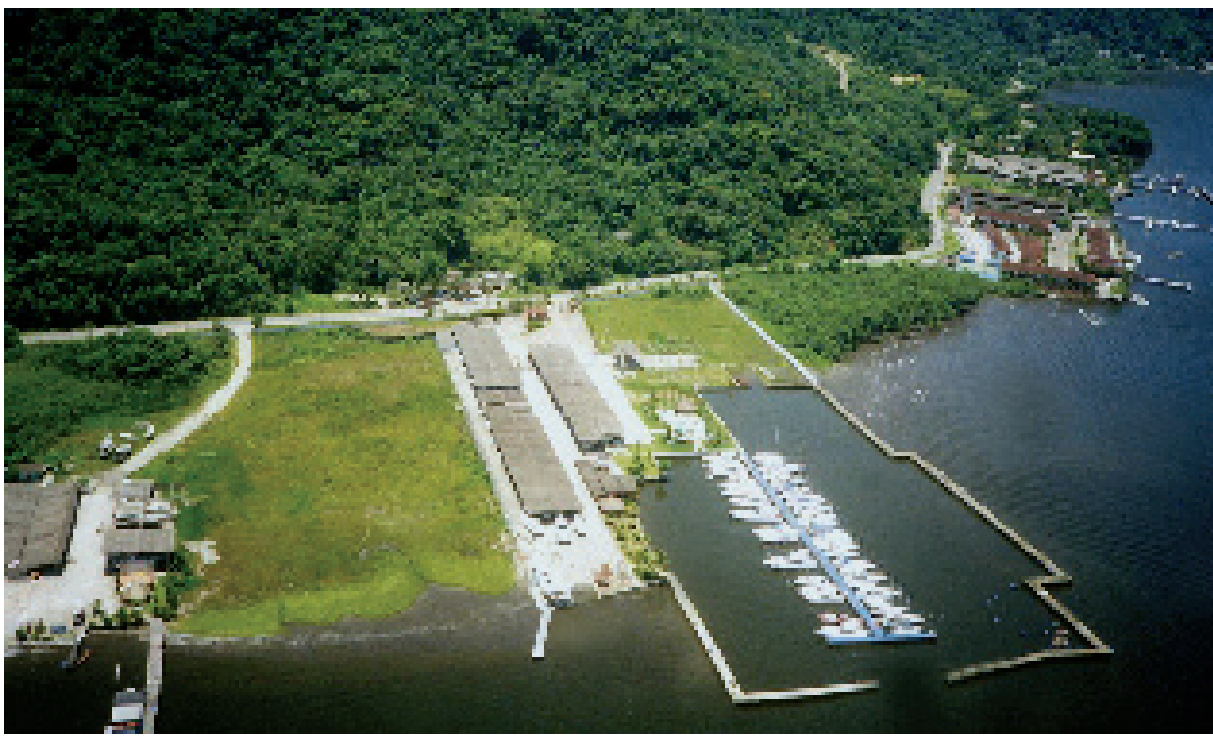

Foto 25:

Marinas para

atracação de

barcos de lazer no

Canal de Bertioga,

município de

Guaruiá (1998) 


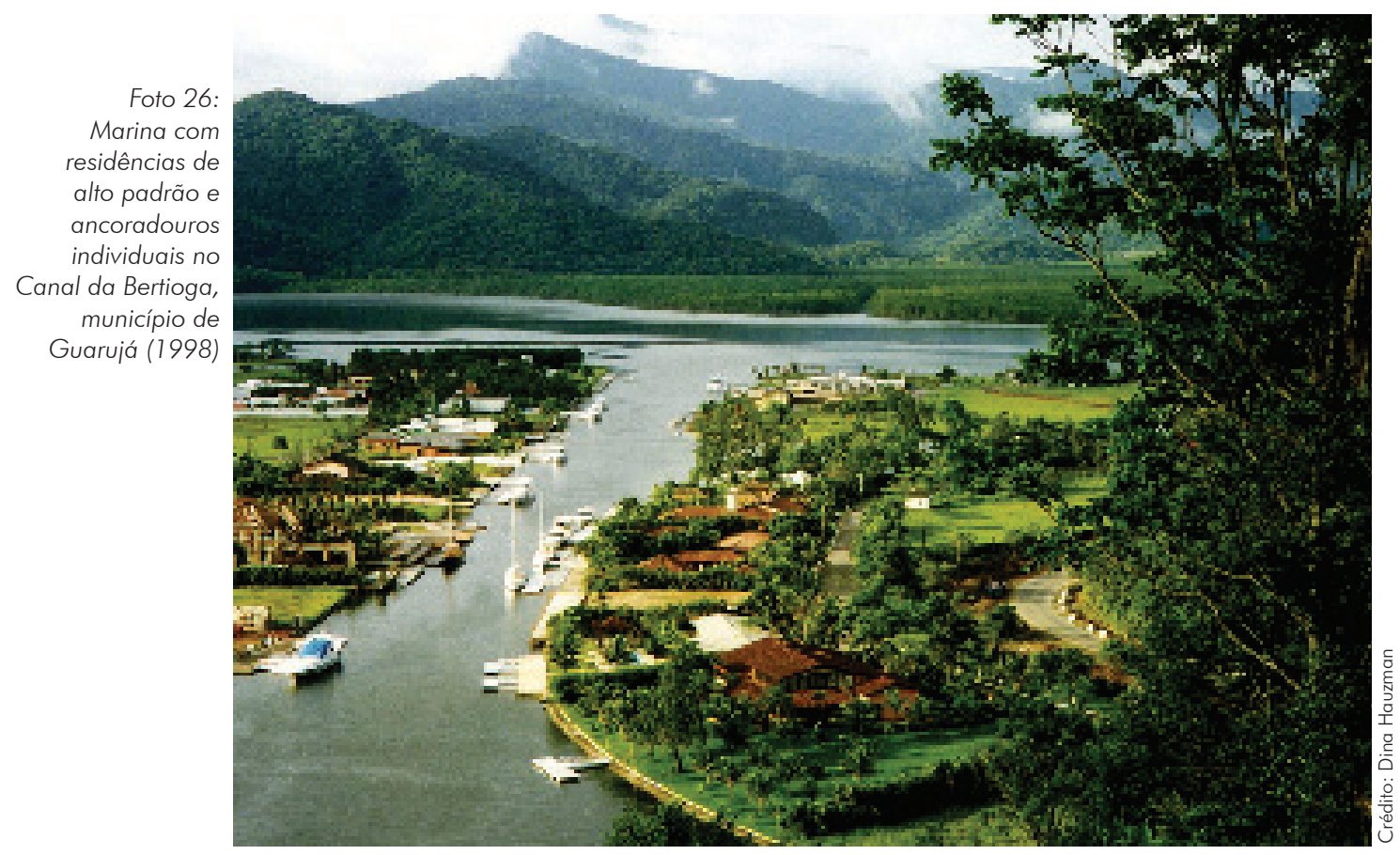

Os clubes se diferenciam na paisagem devido à utilização de grandes glebas e construção de edifícios com dimensões maiores que os comumente encontrados no tecido urbano, mas seu maior destaque se deve à presença de grandes áreas livres, muitas vezes ajardinadas, utilizadas para o lazer dos usuários.

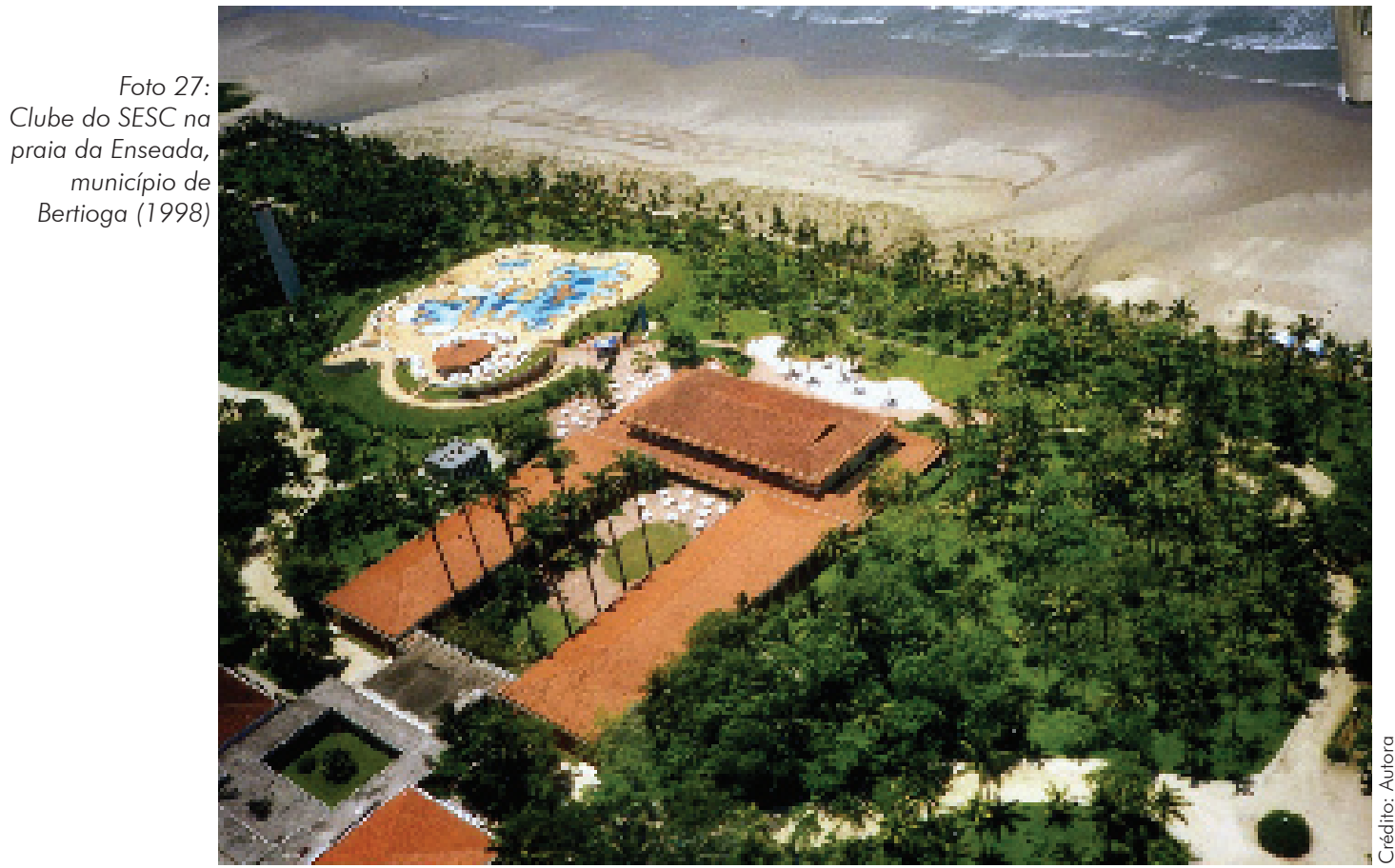


Porto de Santos também apresenta morfologia específica, caracterizada por sua linearidade às margens do Canal de Santos, pela presença dos grandes armazéns para estocagem dos produtos importados ou exportados e pela modificação das margens do canal para construção do cais no qual atracam as embarcações. Também a presença dos grandes guindastes que transportam as mercadorias entre os navios e o cais do porto são característicos dessa paisagem.

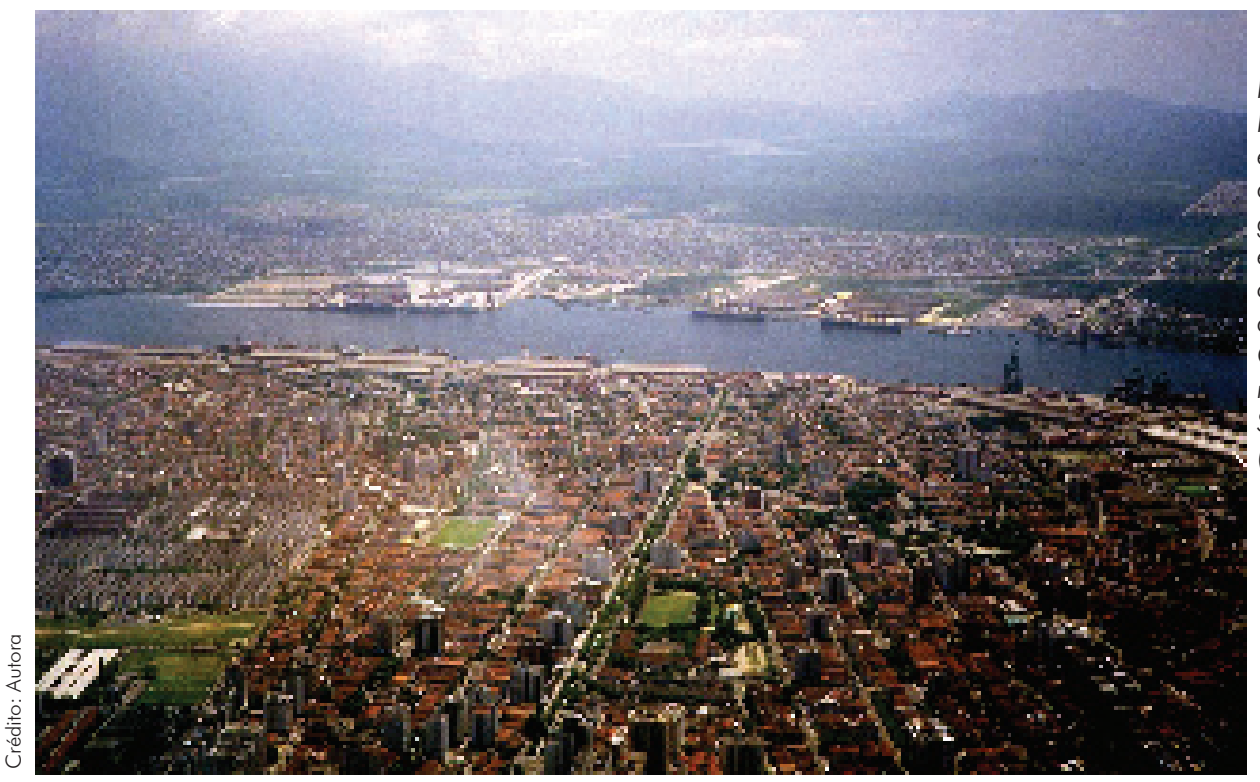

Foto 28:

Porto de Santos e terminais anexos, com seus grandes armazéns e guindastes, ocupando as duas margens do Canal de Santos nos municípios de Santos e Guarujá (1998)

\section{Distribuição Espacial da Mancha Urbana}

\section{Praia Grande e São Vicente (Porção Continental do Município)}

Os terrenos planos próximos à praia têm sido ocupados extensivamente, gerando mancha urbana linear contínua na faixa litorânea por causa da atração que as praias exercem para moradia e lazer. As áreas íngremes ainda permanecem conservadas graças à preferência por urbanizar inicialmente as áreas planas.

A expansão urbana tem se dado por ocupação contínua da faixa litorânea mais distante das praias e por ocupação descontínua da porção interior da planície litorânea. Na faixa litorânea menos valorizada, a ocupação é mais esparsa quanto mais distante está a praia, indicando uma tendência de expansão rumo aos manguezais do rio Piaçabuçu. A urbanização também tem se estendido para as bordas urbanas próximas aos morros, na área de ocupação mais antiga, mais perto de São Vicente.

Na década de 1950, a rodovia e a ferrovia que ligam a Baixada Santista ao litoral sul colocaram-se como obstáculos à expansão urbana, e a área 
Foto 29:

Urbanização extensiva contínua

ocupa a faixa

litorânea do município de Praia

Grande (1999)

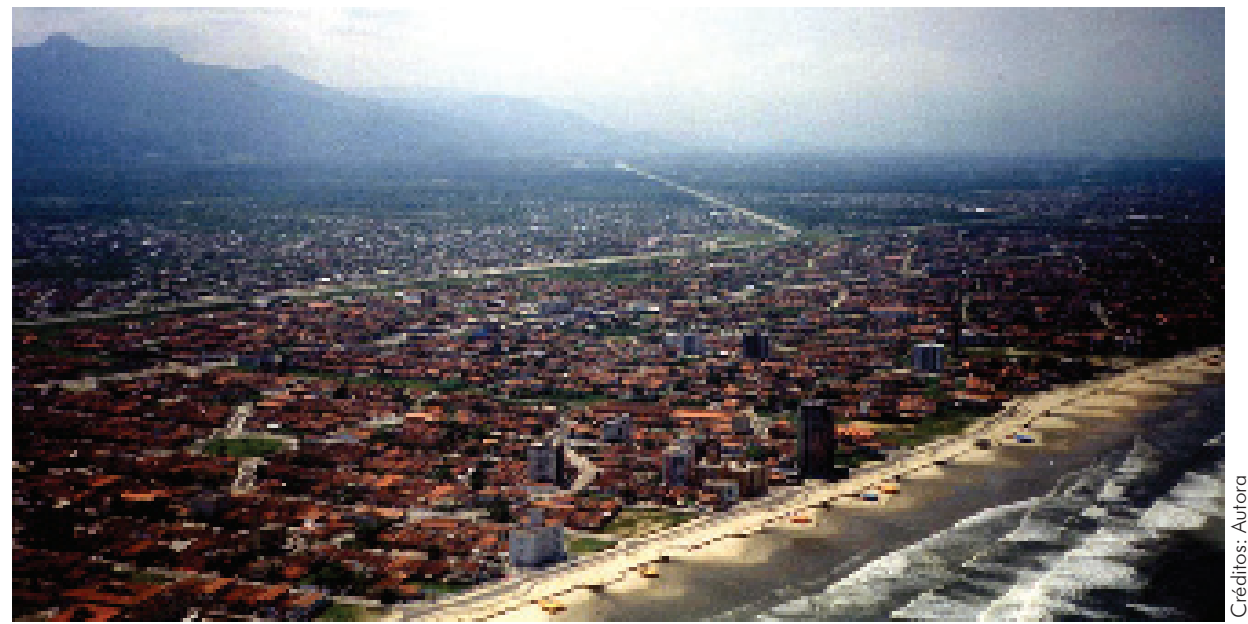

Foto 30:

Área de expansão urbana ocupa

terreno próximo ao

manguezal

(Praia Grande,

1999)

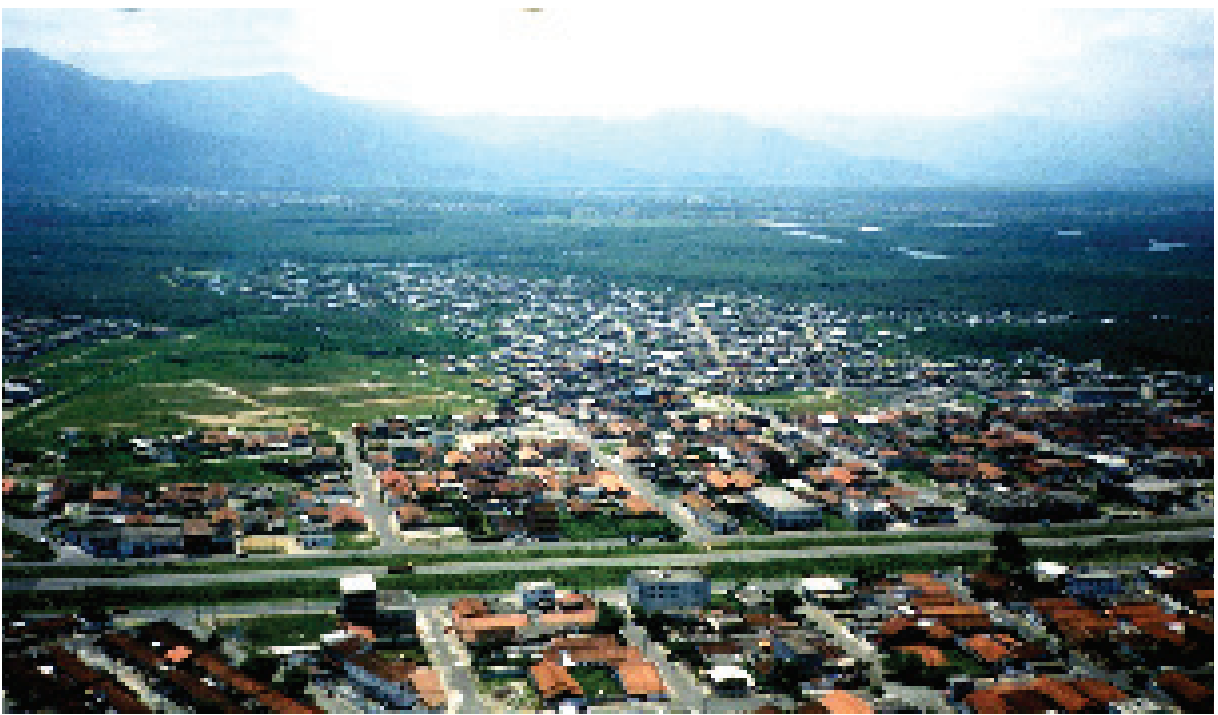

urbana se limitava à faixa contida entre elas e a praia. Somente em um segundo momento esses obstáculos foram ultrapassados pela urbanização. A comparação entre a área urbana no Boqueirão e em Solemar é indicativa desse processo: na faixa litorânea mais distante de São Vicente e Santos (onde se situa o bairro conhecido como Solemar), a mancha linear contínua ocupa apenas os terrenos localizados entre a rodovia e a praia, com ocupação apenas pontual na faixa posterior à rodovia, enquanto no Boqueirão (faixa litorânea mais próxima à llha de São Vicente) essa faixa posterior é continuamente ocupada por expansão urbana.

À ocupação horizontal se acresce adensamento na ocupação das quadras próximas à praia, pela verticalização dessa faixa urbana mais valorizada, ocorrido sem modificação do tecido urbano, sobre a malha viária já existente, expandindo-se linearmente a partir do Boqueirão (área mais próxima a São Vicente e Santos) rumo a Solemar. 
A largura variável da mancha urbana contínua (maior quanto mais próxima à llha de São Vicente), com a verticalização mais intensa na área próxima a São Vicente, indica que a urbanização na Praia Grande tem ocorrido como extravasamento da ocupação da ilha, a área urbana consolidada mais antiga.

Tanto a ocupação inicial quanto a expansão urbana tem se dado por glebas, gerando um tecido urbano fragmentado, apesar de contínuo, do tipo colcha de retalhos. É indicativa do loteamento por glebas a faixa urbana posterior à rodovia na qual áreas de ocupação esparsa mais recente entremeiam áreas

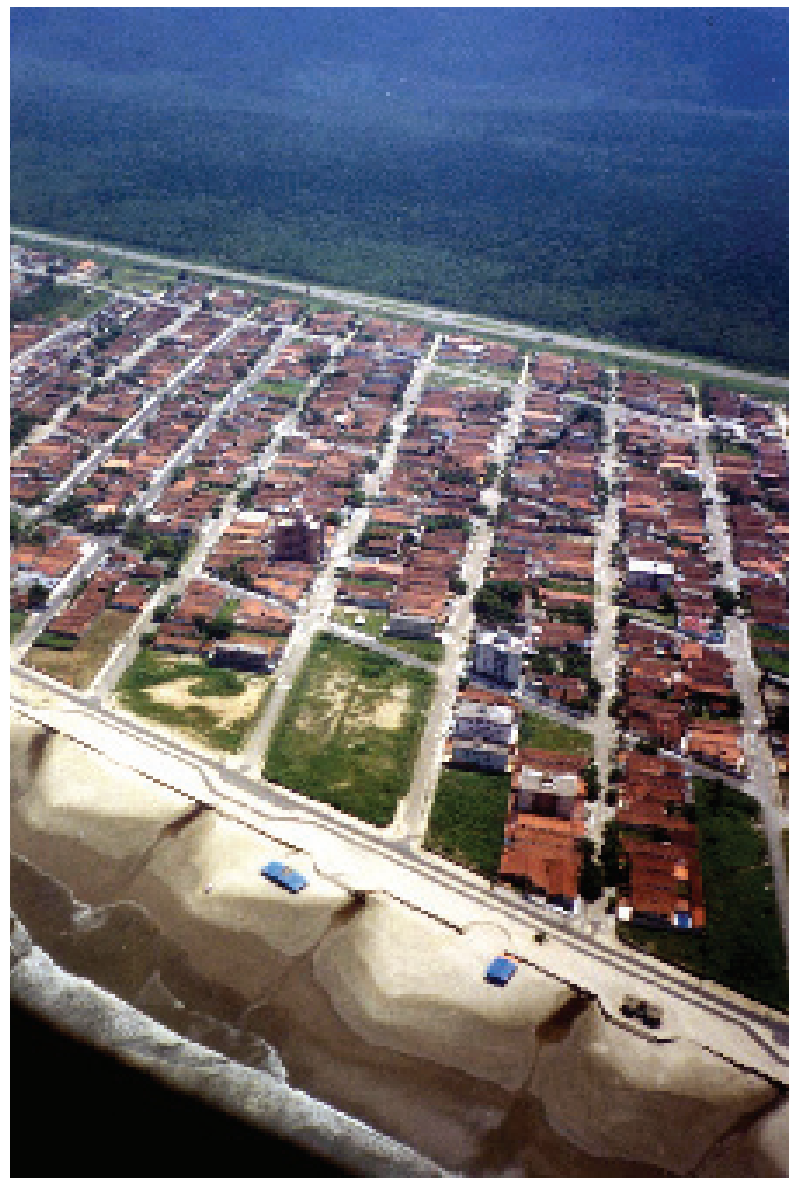

Foto 37 :

A área urbana horizontal permanece contida entre a rodovia Padre Manoel da Nóbrega e a praia (Praia Grande, 1999) urbanas mais antigas e densas. Nessas áreas a ocupação ainda é incompleta, com tendência ao preenchimento dos vazios e expansão linear ao longo da rodovia.

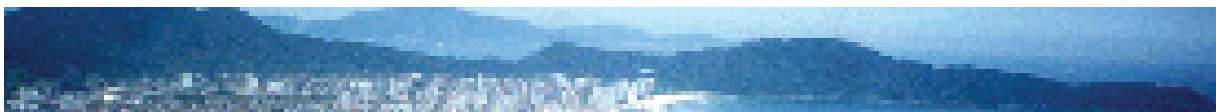

Foto 32:

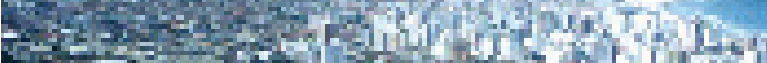

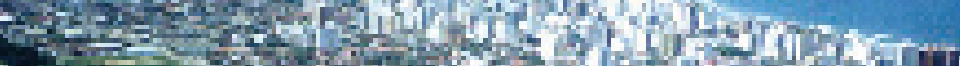

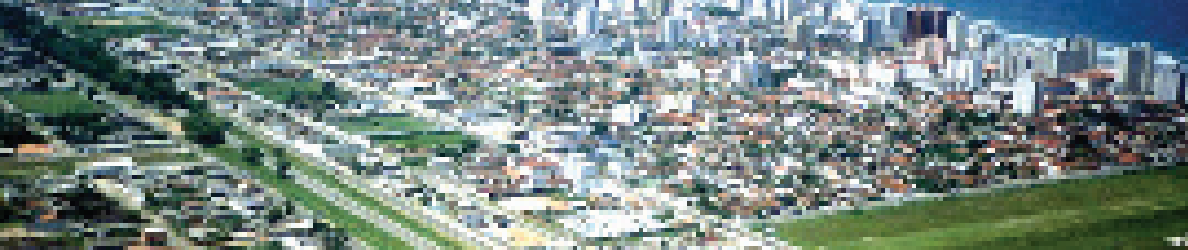

No Boqueirão, a área urbana próxima à praia está verticalizada e a faixa próxima à rodovia está continuamente ocupada por urbanização

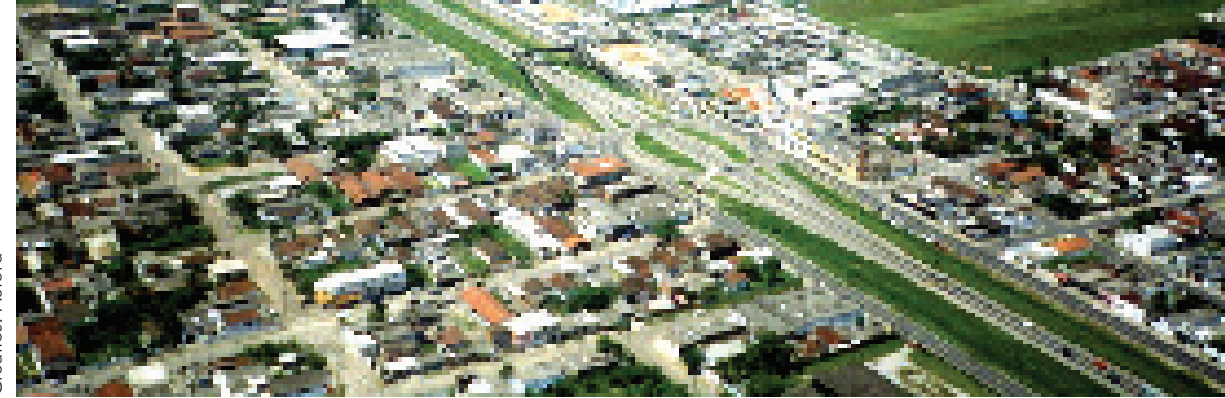
horizontal (Praia Grande, 1999) 

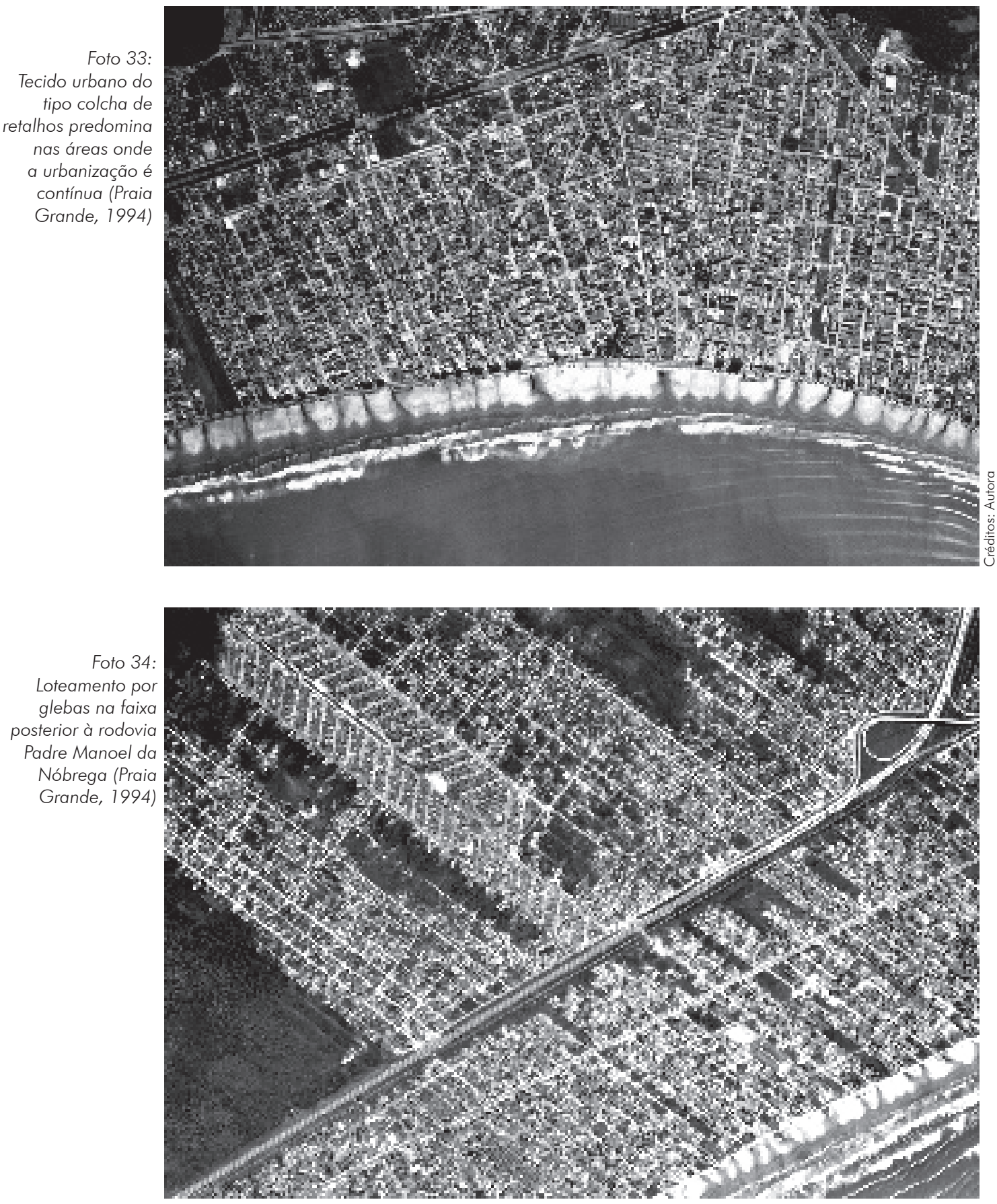

A porção interior da planície sedimentar litorânea, já na parcela continental do município de São Vicente, tem-se urbanizado de forma distinta à faixa litorânea em um processo próximo ao verificado em Cubatão. Áreas residenciais, geralmente habitadas pelos menos favorecidos, espalham-se ao longo da rodovia Padre Manoel da Nóbrega e do leito ferroviário que atravessa a planície, ocupando terras planas afastadas da cidade e, portanto, de menor 
custo, porém com fácil acesso devido à proximidade das vias de transporte. Muitas vezes, aos loteamentos ou conjuntos habitacionais se agregam assentamentos espontâneos que ocupam manguezais e as áreas aterradas próximas à ferrovia.

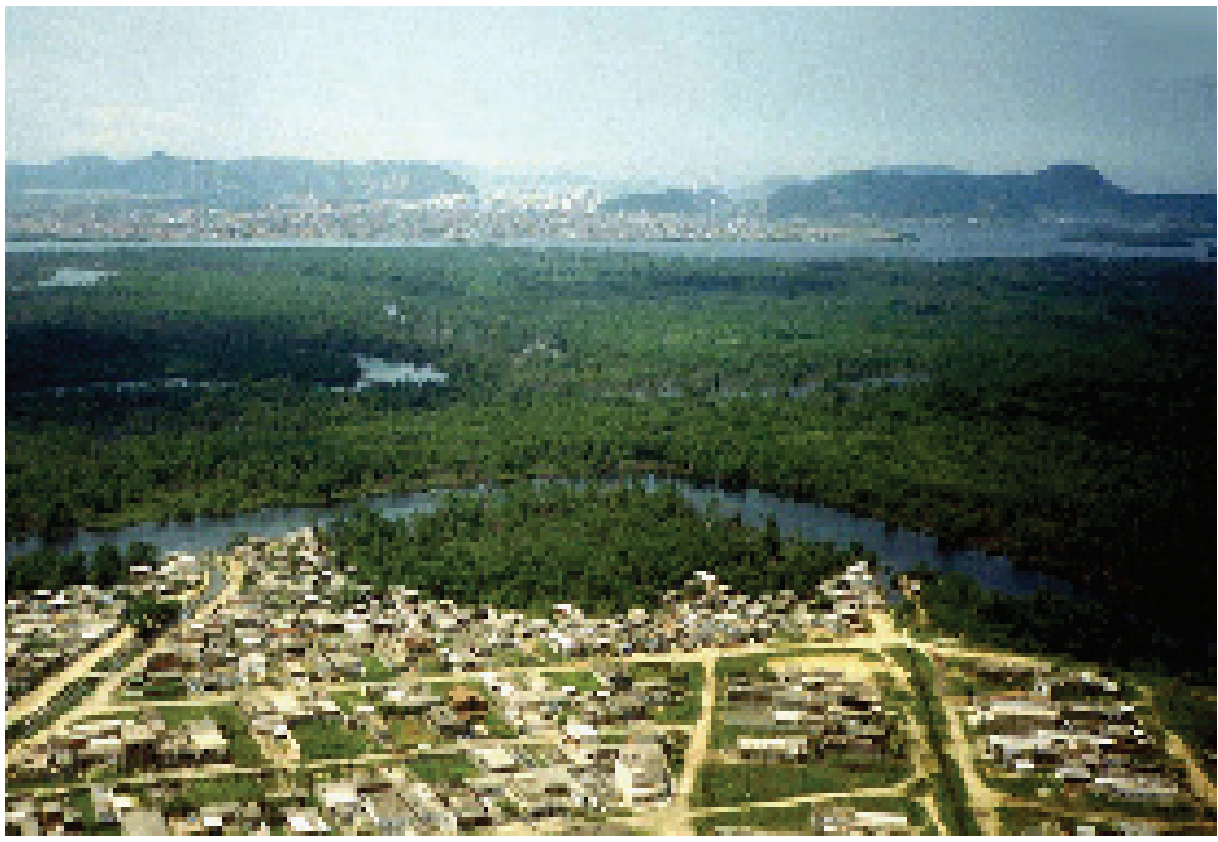

Foto 35:

Assentamento espontâneo ocupa manguezal em loteamento popular oficialmente constituído (São Vicente, 1999)

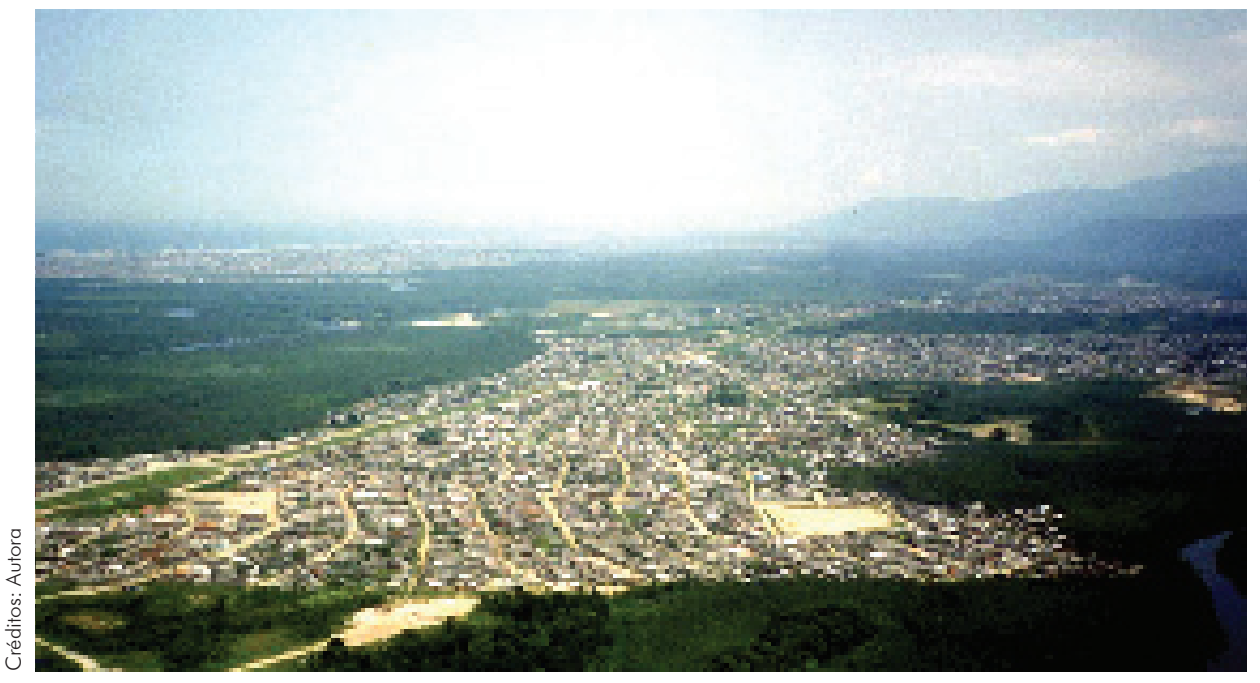

Foto 36:

Bairros residenciais populares se distribuem ao longo da ferrovia que atravessa a planície costeira (São Vicente, 1999)

Área industrial de pequeno porte também ocupa a faixa de terras planas lindeira à rodovia Padre Manoel da Nóbrega, aproveitando a facilidade de acesso e escoamento da produção e a proximidade do rio Branco, fornecedor de água para as atividades industriais e meio propício ao lançamento de efluentes. 


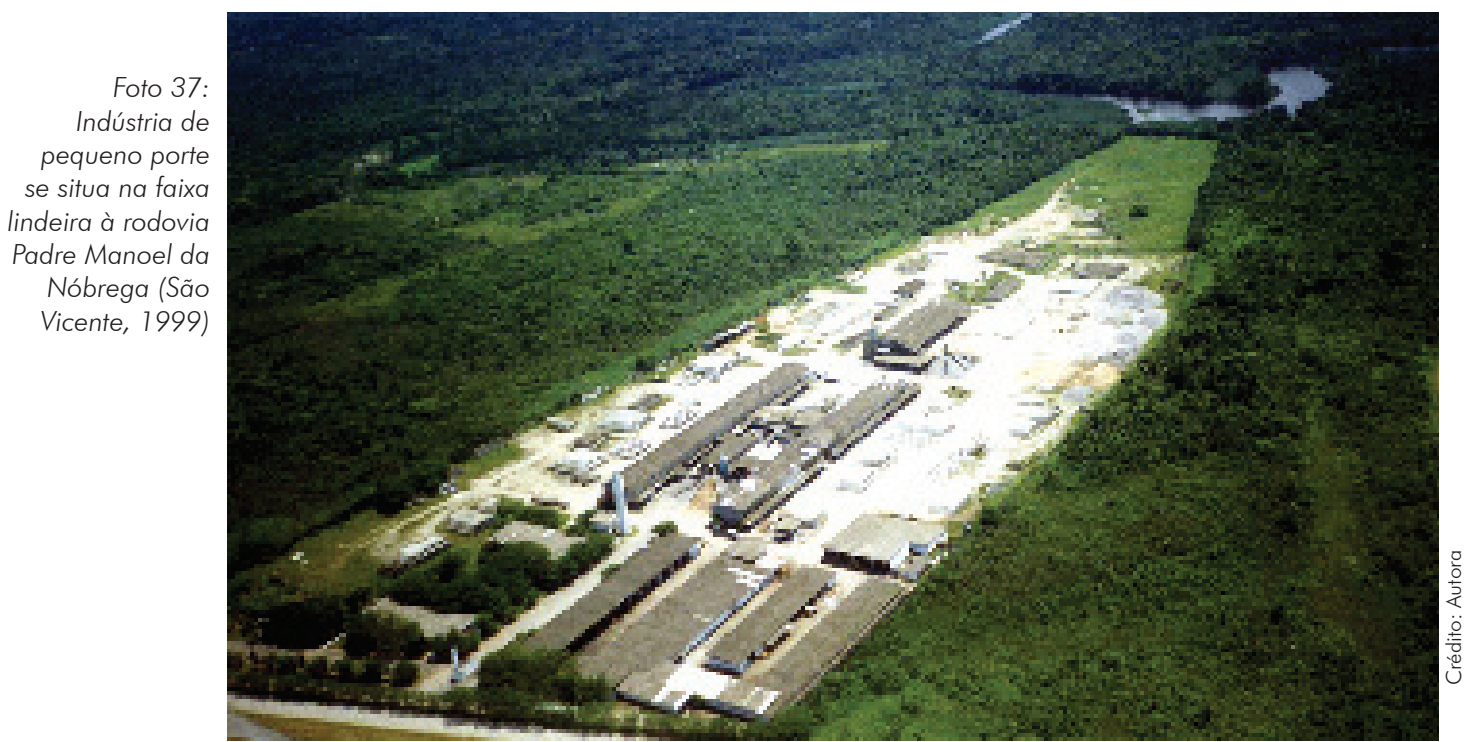

\section{Distribuição Espacial das Áreas Urbanas}

- mancha urbana linear contínua nas praias = atratividade das praias para moradia e lazer

- adensamento/verticalização linear nas praias = áreas de maior valorização

- expansão urbana em mancha linear contínua na faixa litorânea = áreas menos valorizadas, mas próximas da área urbana consolidada

- expansão urbana em mancha descontínua na porção interior da planície litorânea, próxima às rodovias e ferrovia = áreas de fácil acesso em terrenos pouco valorizados

- mancha urbana mais estreita quanto mais distante da llha de São Vicente = urbanização e adensamento como extravasamento da ocupação da ilha

- áreas íngremes conservadas

\section{Cubatão}

A mancha urbana consolidada correspondente ao centro de Cubatão e aos poucos bairros residenciais de classe média baixa é limitada pelo leito da ferrovia, pela via Anchieta e pelo rio Cubatão, obstáculos de difícil transposição pela urbanização.

A outra mancha urbana consolidada situa-se quase no limite municipal Cubatão-Santos e corresponde a bairro residencial de classe média baixa, loteado na época da construção da via Anchieta. Ao bairro mais antigo se agregam áreas urbanas recentes e de ocupação mais esparsa. 


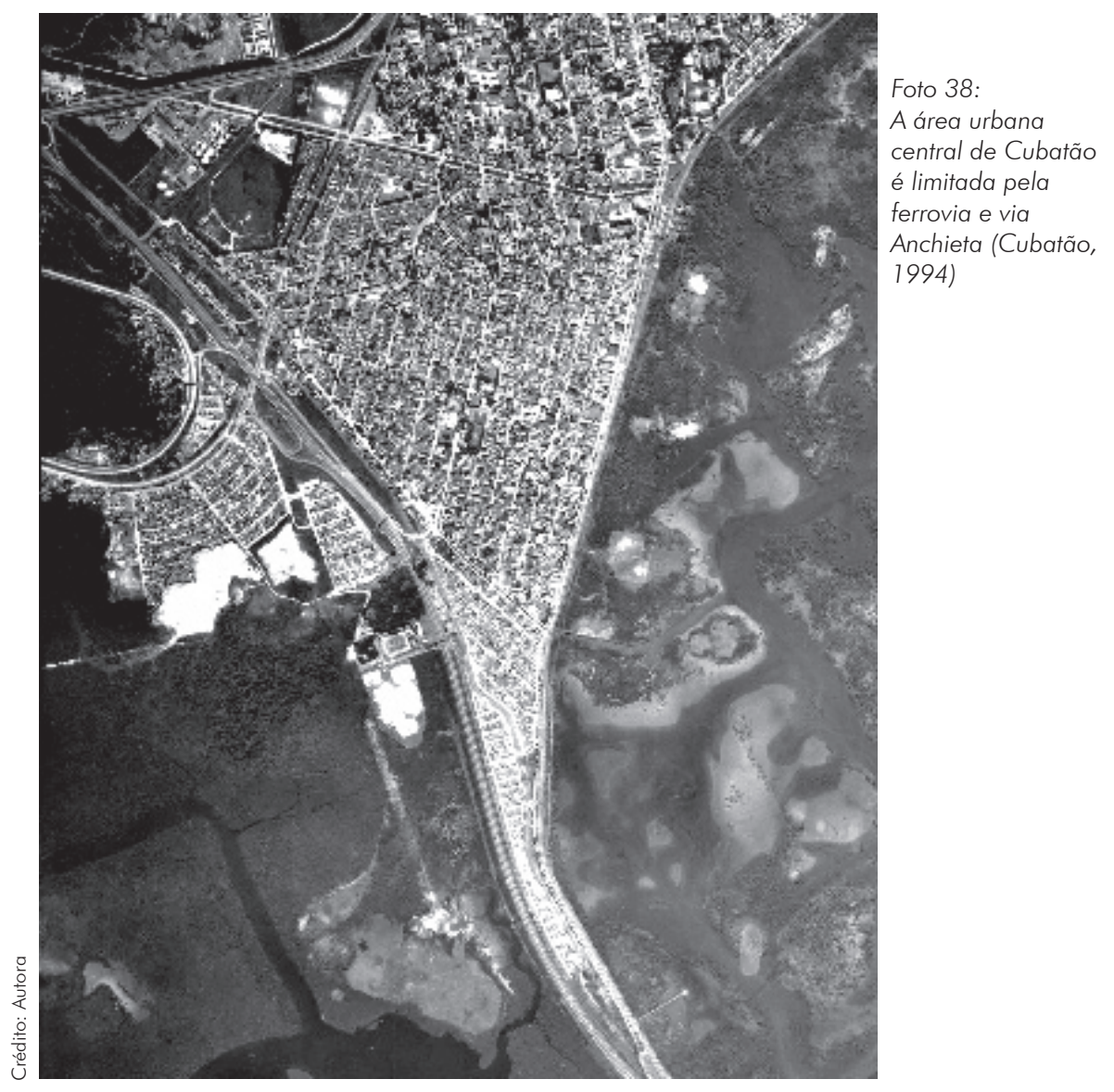

Como a disponibilidade de terras planas não-inundáveis é pequena em Cubatão e, em sua maioria, já ocupada pelas indústrias e pela área urbana já consolidada, os novos conjuntos habitacionais e os bairros residenciais habitados pelos menos favorecidos têm sido construídos sobre áreas de manguezal aterrado ou nas encostas da Serra do Mar.

A expansão urbana de Cubatão se deve ao crescimento dos bairros pobres, ocupados pelos trabalhadores de baixa renda. Esses assentamentos espontâneos se apresentam em mancha linear descontínua, distribuída nas rodovias Imigrantes ou Anchieta, nos aterros ferroviários ou próximos ao rio Cubatão. Sua forma e localização devem-se à busca de fácil acesso (principalmente em virtude da proximidade das rodovias) em terras de baixo ou nenhum custo (encostas da Serra, no Parque Estadual da Serra do Mar ou manguezais).

O Parque Industrial de Cubatão ocupa as áreas planas não-inundáveis do município em mancha urbana radial, na busca da otimização das condições de produção industrial: as indústrias ali sediadas são, em sua maioria, do ramo petroquímico, o que determina a busca da proximidade à refinaria de petróleo Presidente Bernardes (Petrobrás) para fácil abastecimento de matéria-prima. 
Foto 39:

Assentamento espontâneo linear aproveita os aterros das rodovias

Padre Manoel da Nóbrega e Imigrantes (Cubatão, 1998)
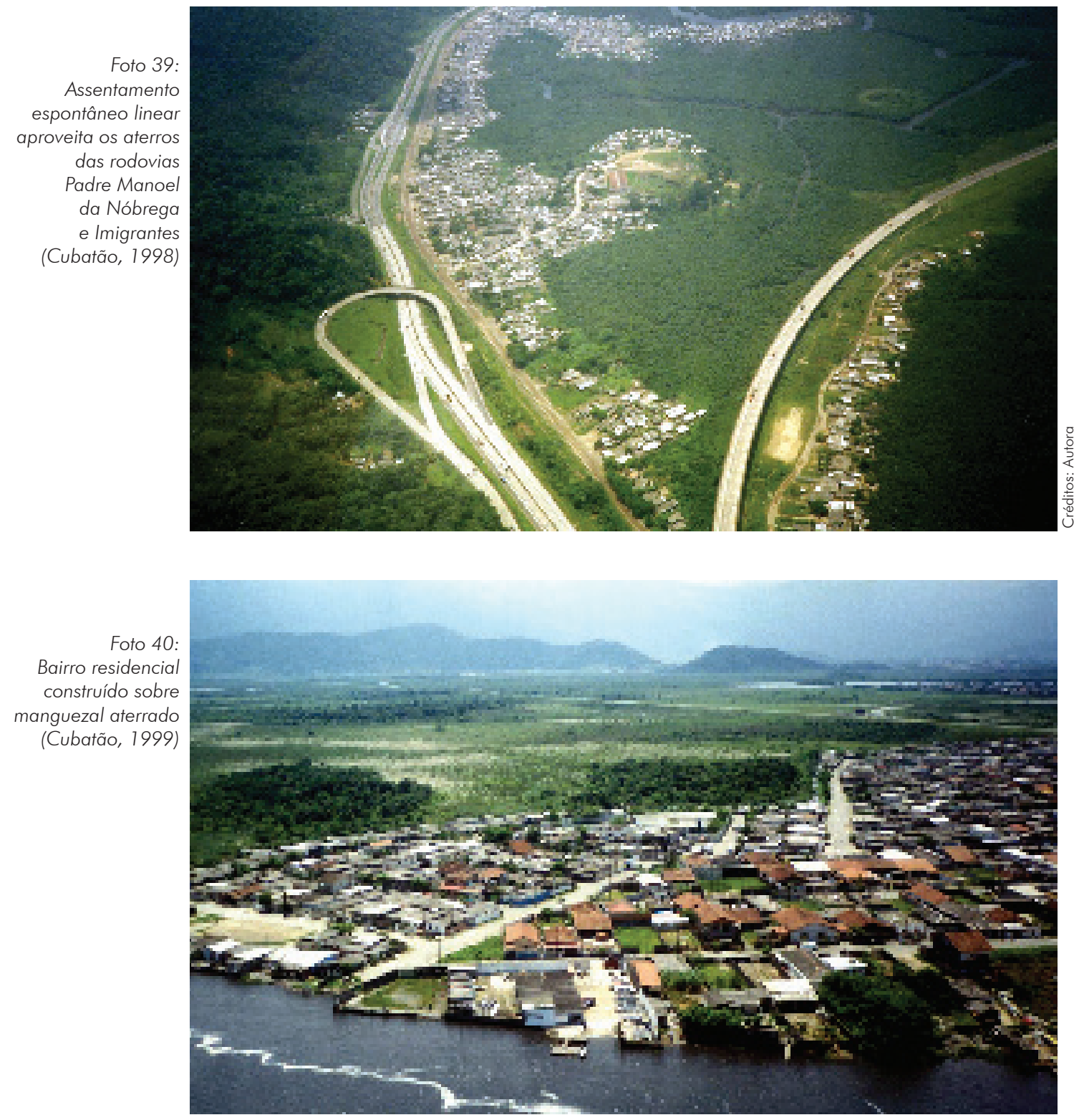

Também são determinantes da concentração industrial a preferência por áreas planas para a construção das instalações industriais, a busca pelo fácil abastecimento de água e energia (via rio Cubatão e Usina Henry Borden) e a proximidade do porto e rodovias para escoamento da produção.

No vale do rio Moji, a maioria das indústrias pertence ao ramo de fertilizantes. Essas fábricas se instalaram em Cubatão, posteriormente às petroquímicas, e, portanto, ficaram mais distantes da refinaria de petróleo, a fornecedora de matérias-primas. Apesar de ocuparem área restrita, preferiram-na graças à proximidade da estrada de ferro para escoamento da produção e à proximidade do rio Moji para abastecimento e lançamento de efluentes. 


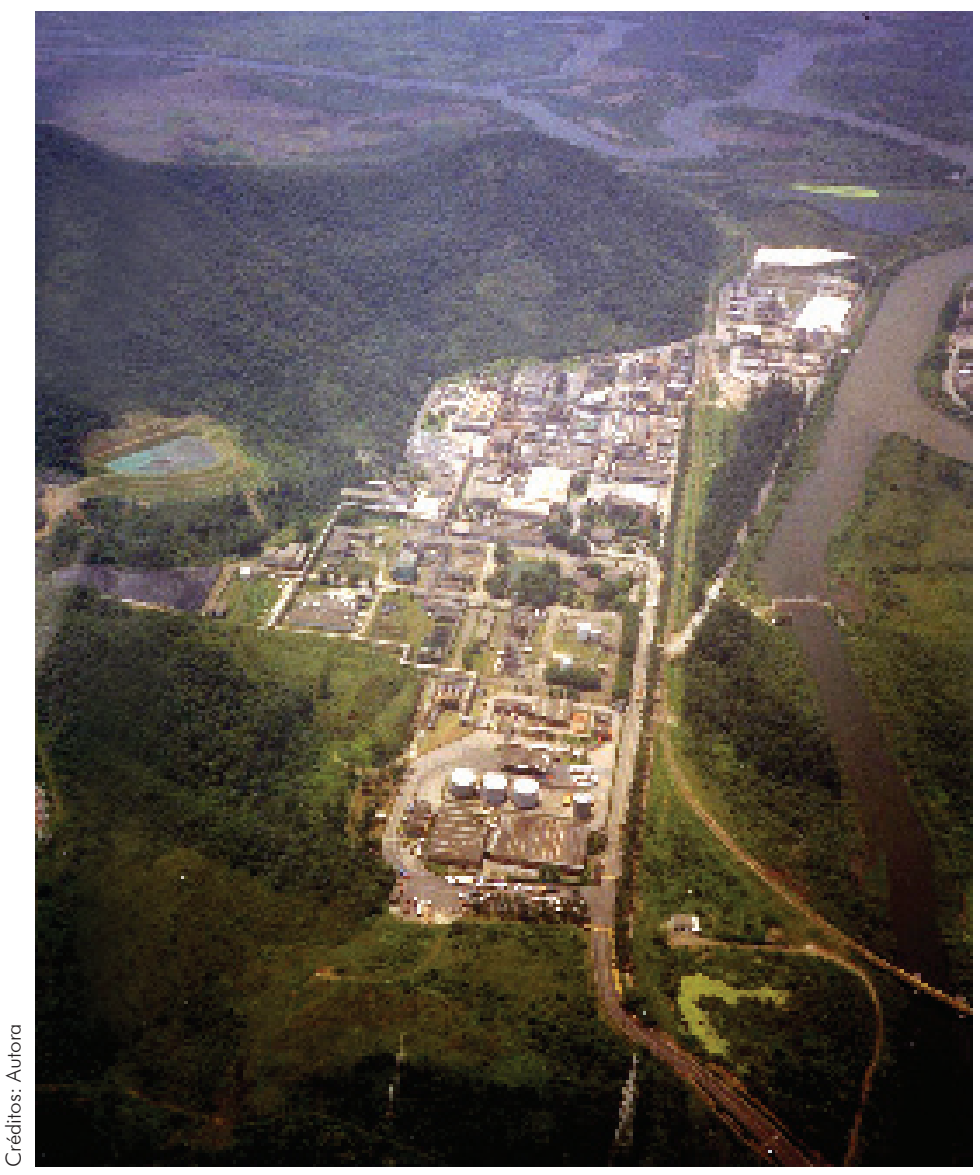

Foto 41:

Indústria localizada em terreno plano próximo ao rio

Perequê e à rodovia Piaçagüera-Guarujá (Cubatão, 1998)

A Companhia Siderúrgica Paulista (Cosipa) teve sua localização motivada pela proximidade do rio Moji (abastecimento de água e lançamento de efluentes) e pela proximidade do Canal de Piaçagüera (construção de porto próprio para abastecimento e escoamento da produção).

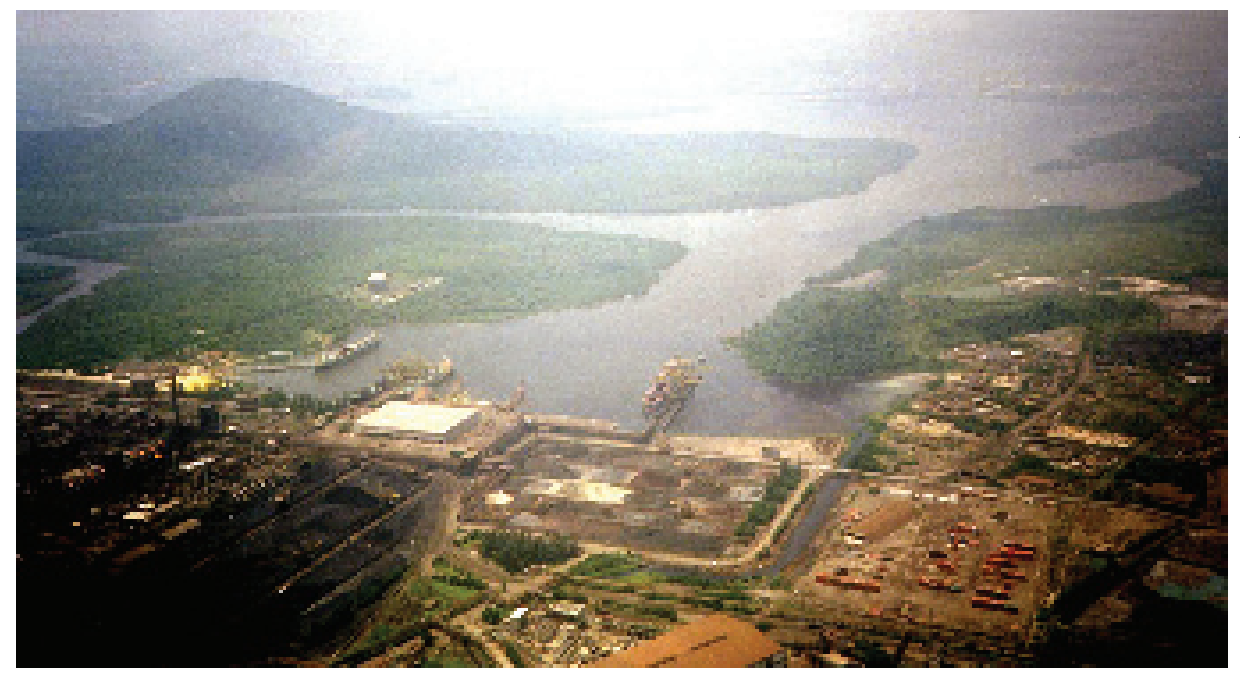

Foto 42

A Companhia

Siderúrgica Paulista (Cosipa) se localiza no Canal de Piaçagüera, no qual foi construído terminal portuário próprio para recebimento de matérias-primas e escoamento da produção (Cubatão, 1998) 


\section{Ilha de São Vicente}

As terras planas da llha de São Vicente são quase totalmente urbanizadas, predominando a ocupação horizontal. Áreas de verticalização consolidada ocorrem sobre a malha viária preexistente na faixa paralela às praias, por seu interesse turístico ou como moradia da população local mais abastada. Também é mais adensada a área central de Santos, próxima ao Monte Serrat, em que estão sediadas funções de comércio e serviços de porte regional.

morro que ocupa a porção central da ilha ainda é pouco urbanizado, mas habitações dos trabalhadores da região central e do setor portuário ocupam as áreas íngremes próximas ao porto e ao centro da cidade de Santos desde o final do século XIX, quando ocorreu grande afluxo de trabalhadores à região santista.

Foto 43:

A urbanização

se distribui, preferencialmente, sobre as áreas planas e o maciço central é pouco urbanizado no município de Santos (1999)

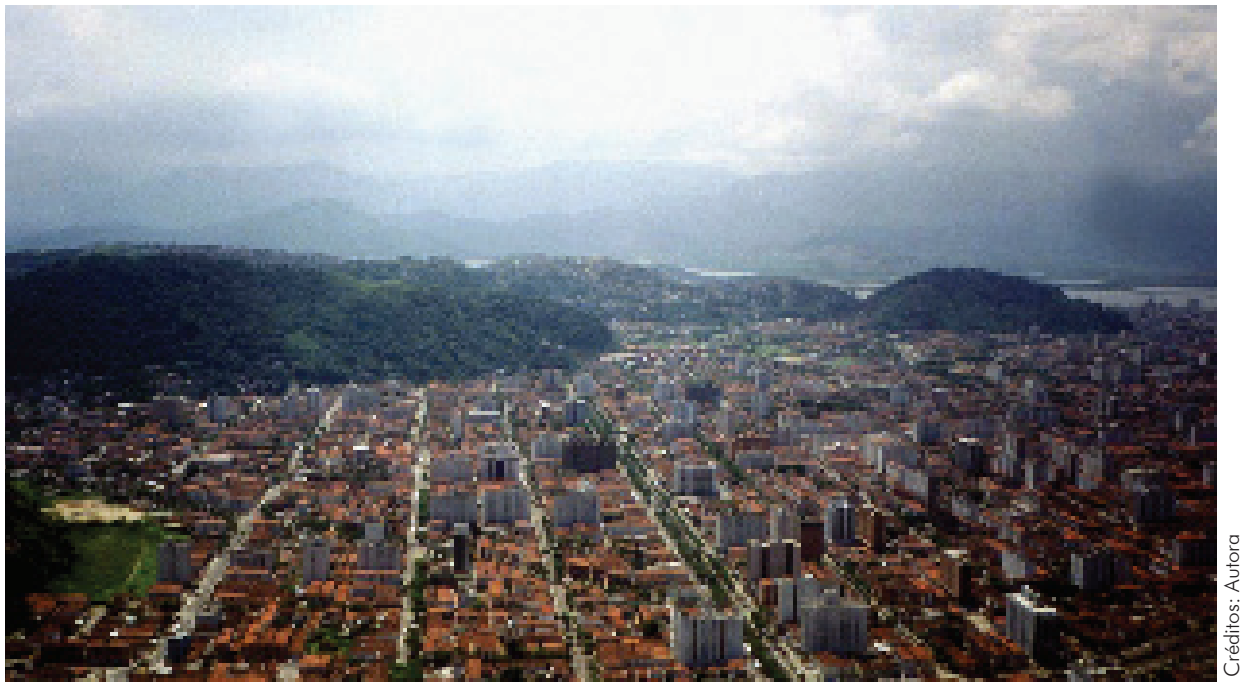

Foto 44: A verticalização predomina nos terrenos situados de frente para o mar (Santos e São Vicente, 1999)

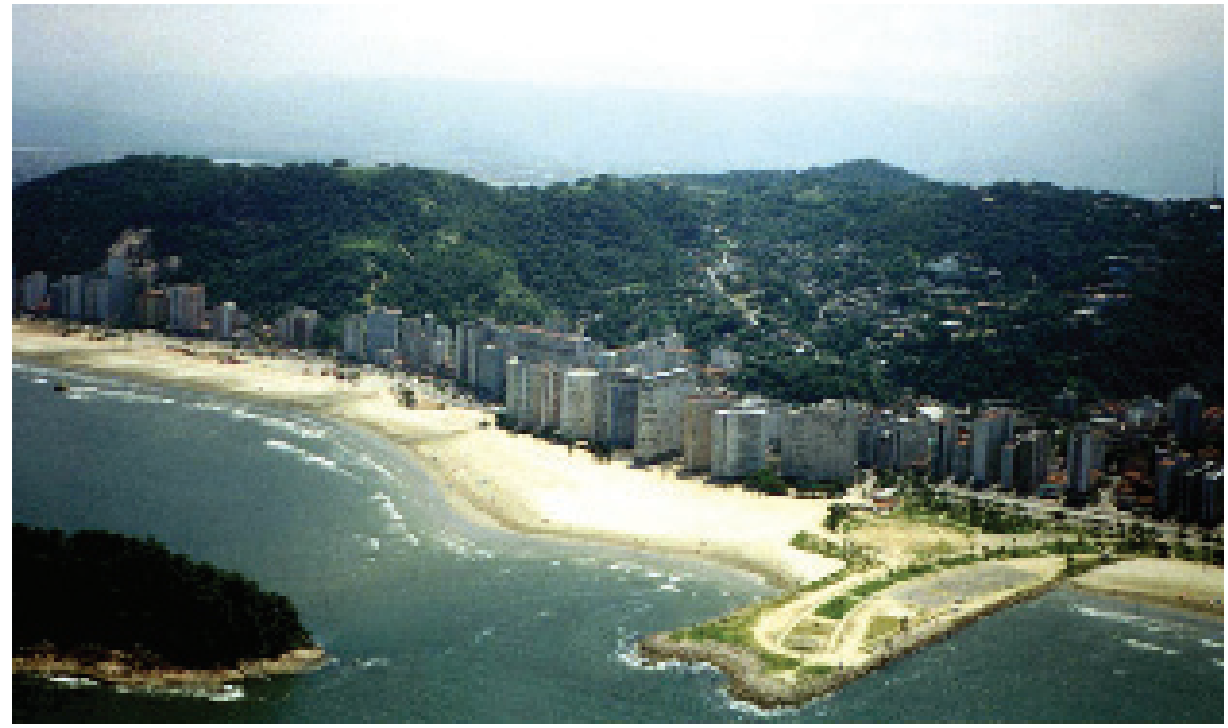


Nas porções íngremes próximas às praias, a urbanização predominante é distinta, composta por loteamentos de alto padrão que privilegiam a vista para o mar, tal como acontece na llha Porchat e no Morro Santa Terezinha. Recentemente, assentamentos espontâneos habitados por população carente começam a entremear esses loteamentos, estando até agora restritos ao Morro de Santa Terezinha.
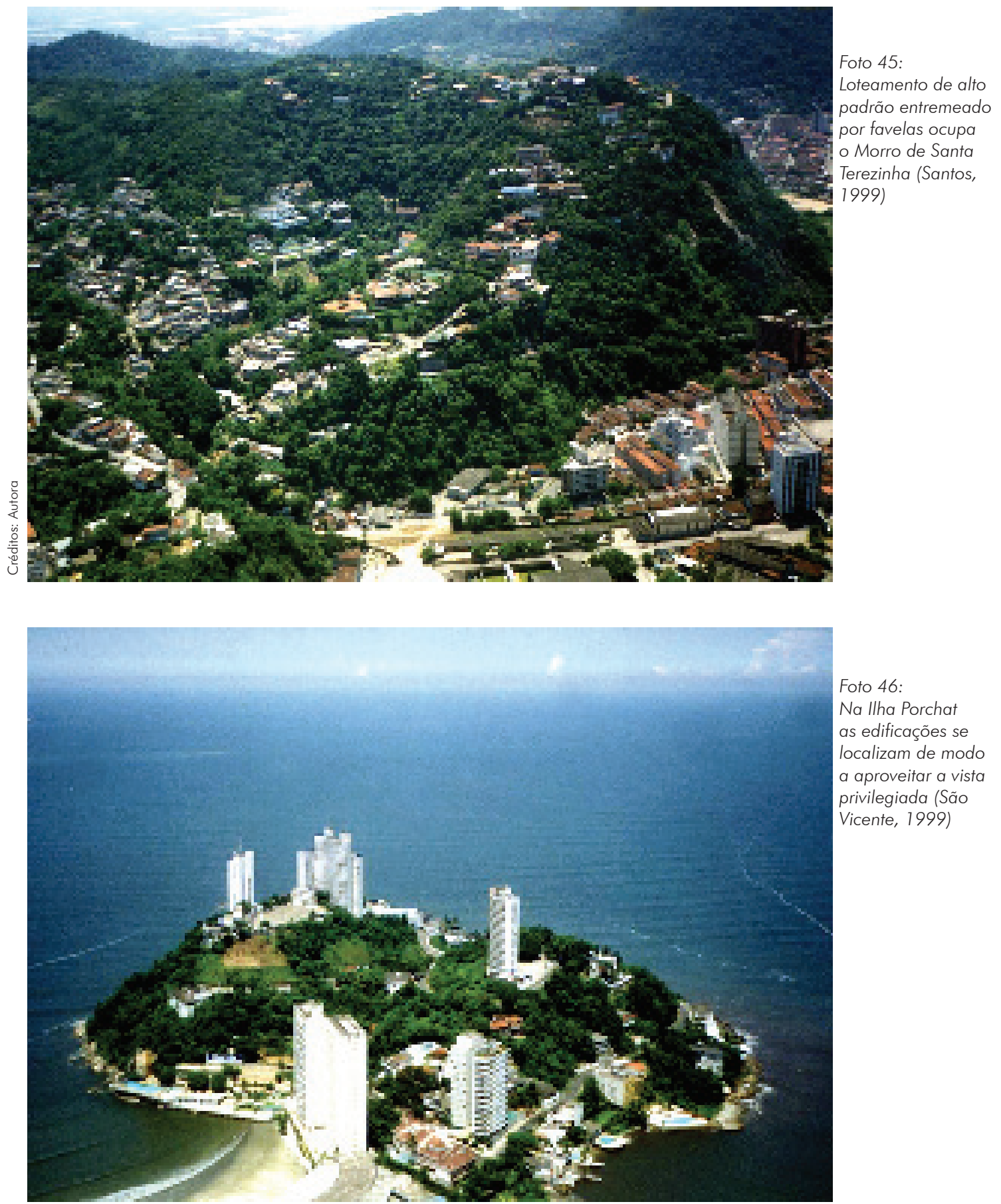

Foto 46:

Na llha Porchat as edificações se localizam de modo a aproveitar a vista privilegiada (São Vicente, 1999) 
preenchimento urbano das áreas planas insulares induziu a transposição do canal para a expansão urbana, como se verifica com o bairro residencial de Vicente de Carvalho, no município de Guarujá.

$\bigcirc$ porto que, originalmente, ocupava parte da margem insular do Canal de Santos, expandiu-se linearmente ao longo do canal, hoje abrangendo desde - Largo do Canéu até quase a boca do canal, na Baía de Santos. À expansão linear se somou também a transposição do canal, com a ocupação parcial de sua margem oposta, no município de Guarujá. Agregam-se, ainda, ao porto, atividades correlatas, relacionadas a armazenamento e transporte de produtos comercializados por via marítima que buscaram otimizar suas condições de comercialização e produção pela proximidade ao porto, motivo da criação da Vila Industrial da Alemoa, no Largo do Canéu.

Foto 47:

A expansão urbana e portuária de

Santos ocupa também a margem oposta do canal, no município de Guarujá (Santos e Guarujá, 1999)

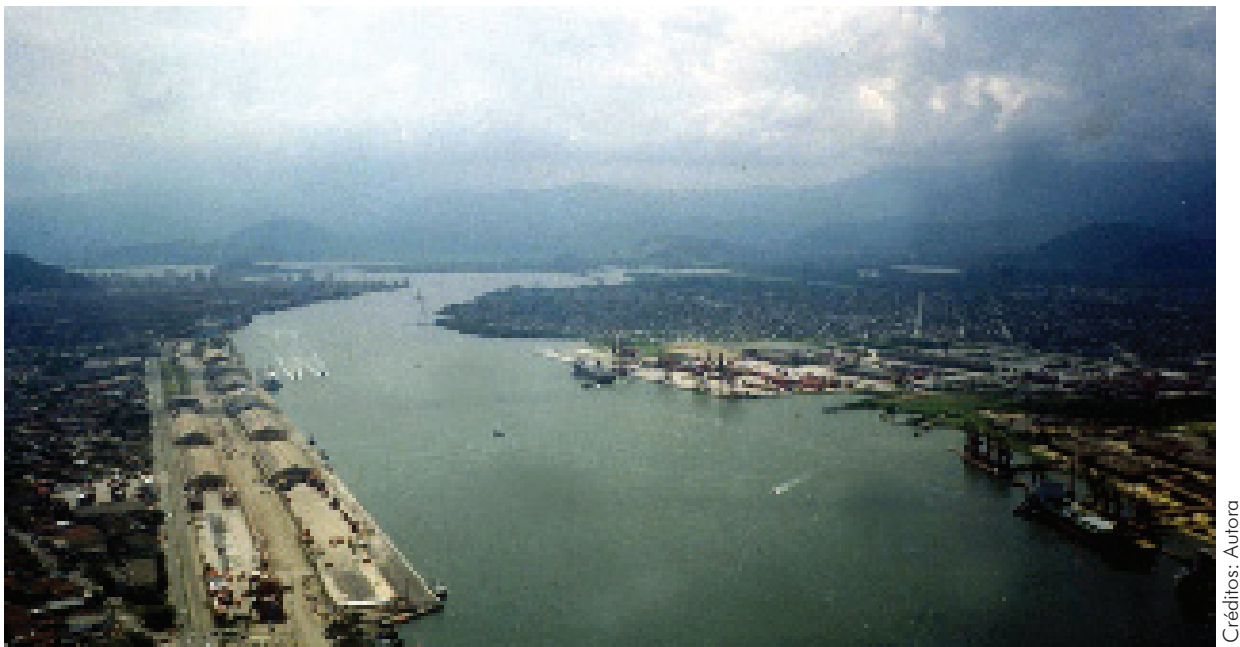

Foto 48: Manguezal que ocupava as margens do Canal dos Barreiros é substituído por favela em continuidade à urbanização horizontal extensiva da llha de São Vicente (São Vicente, 1999)

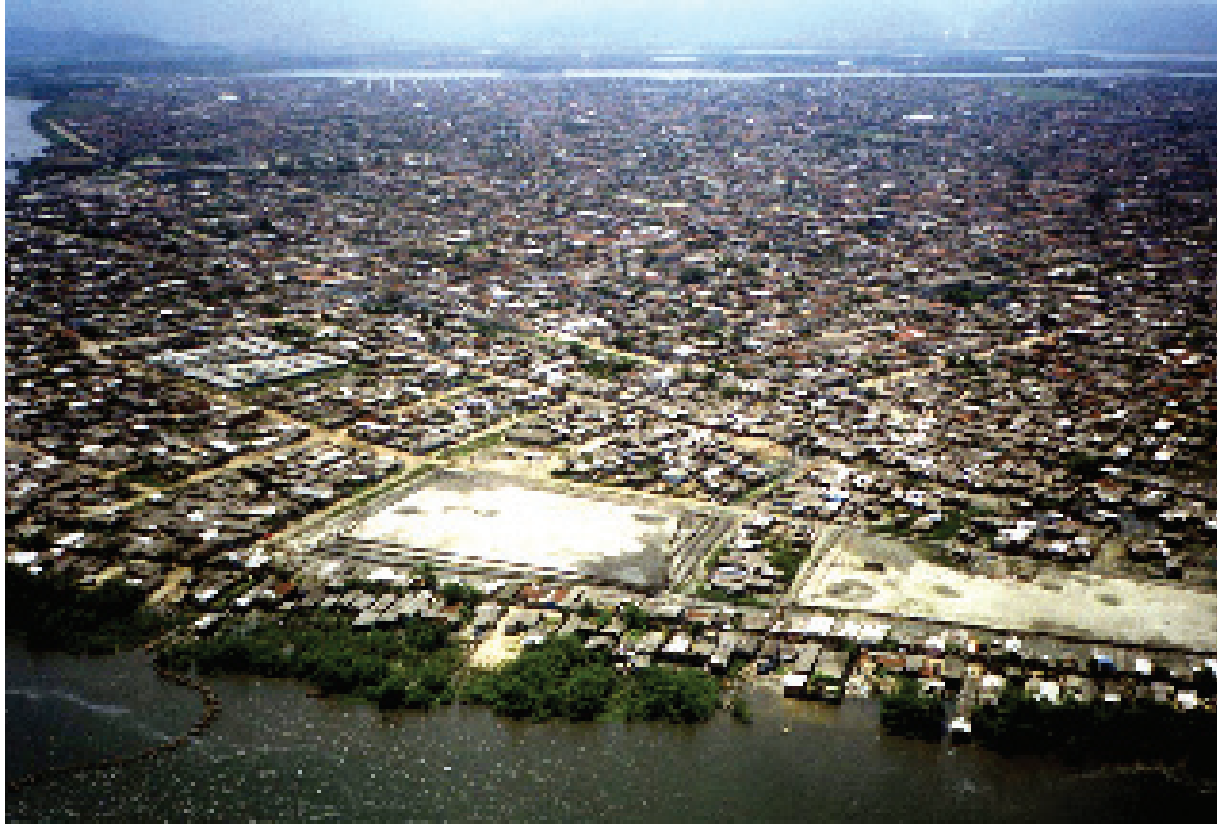


A última frente de expansão urbana na llha de São Vicente tem como eixo a rodovia dos Imigrantes, a qual atravessa uma de suas últimas áreas nãourbanizadas. Com o preenchimento das áreas planas não-inundáveis da ilha, também os manguezais remanescentes em São Vicente, que permaneciam não-ocupados por seu menor valor imobiliário, estão sendo ocupados por assentamentos espontâneos.

A não-transposição do Canal dos Barreiros, na porção insular correspondente ao município de São Vicente, indica que o centro polarizador da urbanização é o centro de Santos. A área urbana da ilha expandiu-se a partir desse centro, em dois sentidos: rumo ao Guarujá (com sua margem do Canal de Santos quase totalmente ocupada por atividades urbanas) e rumo a São Vicente (que só agora tende a completar a urbanização na ilha e ainda não ocorrendo extravasamento urbano para a margem oposta do canal).

\section{Distribuição das Áreas Urbanas em Cubatão}

- área urbana consolidada = mancha urbana restrita = rodovia, ferrovia e rio como obstáculos

- área de expansão urbana = mancha urbana linear descontínua = acessibilidade e baixo custo da terra

- área industrial = mancha urbana radial descontínua

- lógica da mancha urbana radial = concentração industrial para otimização de custos e condições de produção

- lógica da mancha urbana descontínua = preferências locacionais (proximidade a rios, terrenos planos, rodovias ou ferrovia)

\section{Distribuição das Áreas Urbanas na Ilha de São Vicente}

- mancha urbana horizontal extensiva quase completa = núcleo urbano mais importante

- verticalização nas praias = áreas mais valorizadas para moradia e turismo

- transposição urbana no Canal de Santos (Guarujá) = busca da concentração

- não-transposição urbana no Canal dos Barreiros (São Vicente) = centro urbano polarizador em Santos

\section{Guarujá}

A urbanização linear próxima às praias deve-se, principalmente, ao turismo de segunda residência. A partir do núcleo urbano inicial, localizado na praia das Pitangueiras, a área urbanizada se expandiu sucessivamente pelas praias adjacentes, hoje se estendendo desde a praia de Guaiúba até a praia do 
Perequê. A expansão horizontal se soma ao importante processo de verticalização que ocorre de forma linear na costa. Ao mesmo tempo urbanizam-se também os terrenos mais distantes da praia, adjacentes à área urbana.

padrão de urbanização predominante, composto por glebas regularmente loteadas, aqui, como no restante da Baixada Santista, ocupa somente as áreas planas, e seus limites coincidem, grosso modo, com o sopé dos morros.

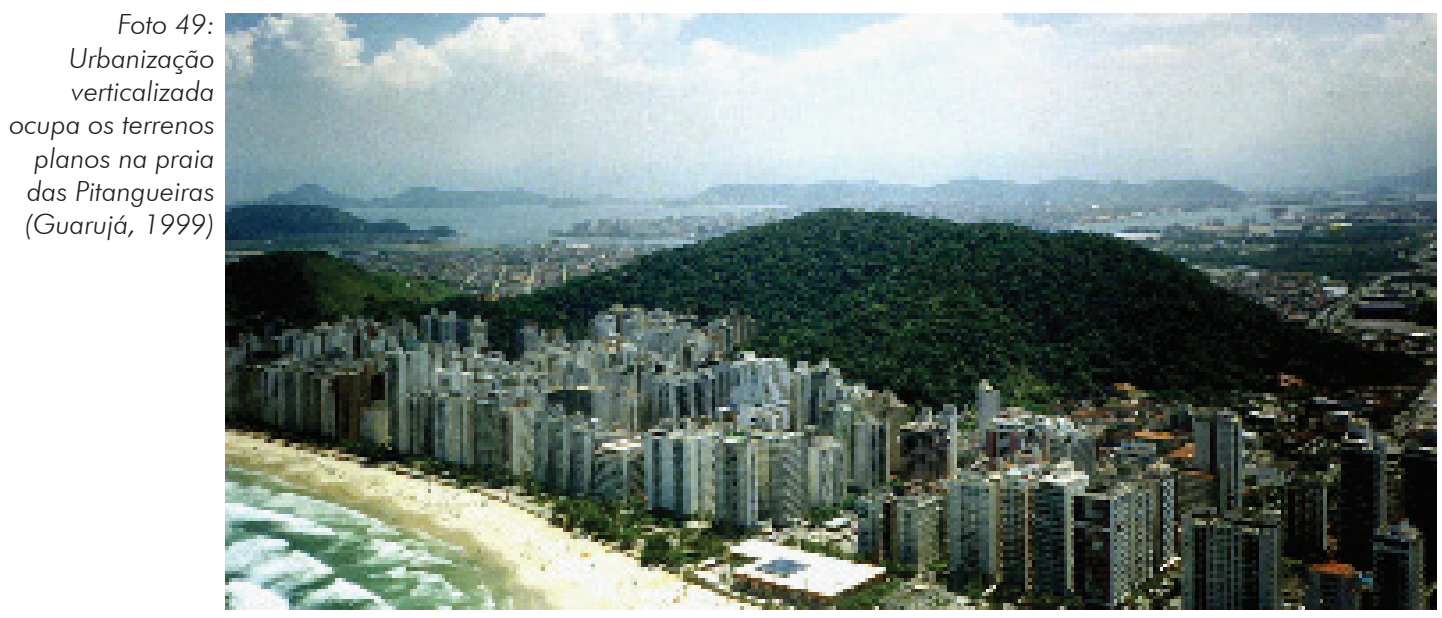

Foto 50:

Expansão urbana em processo de verticalização caracteriza os terrenos planos da praia do Tombo (Guarujá, 1999)

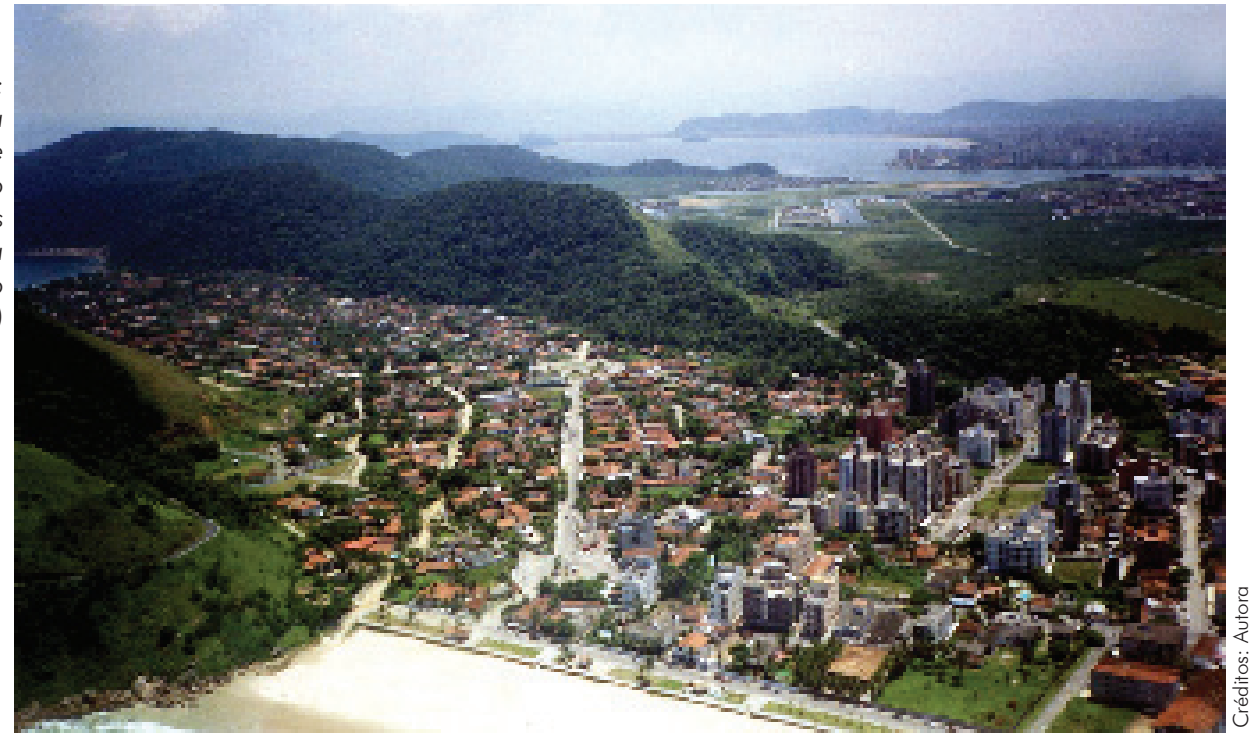

A esse padrão se soma, no Guarujá, a ocupação urbana dos morros próximos ao mar e a urbanização de praias isoladas por loteamentos de alto padrão que privilegiam o isolamento (o acesso é permitido somente aos proprietários), a vista para o mar e o contato com a natureza por meio da conservação da vegetação natural, gerando manchas urbanas restritas circundadas por vegetação. 


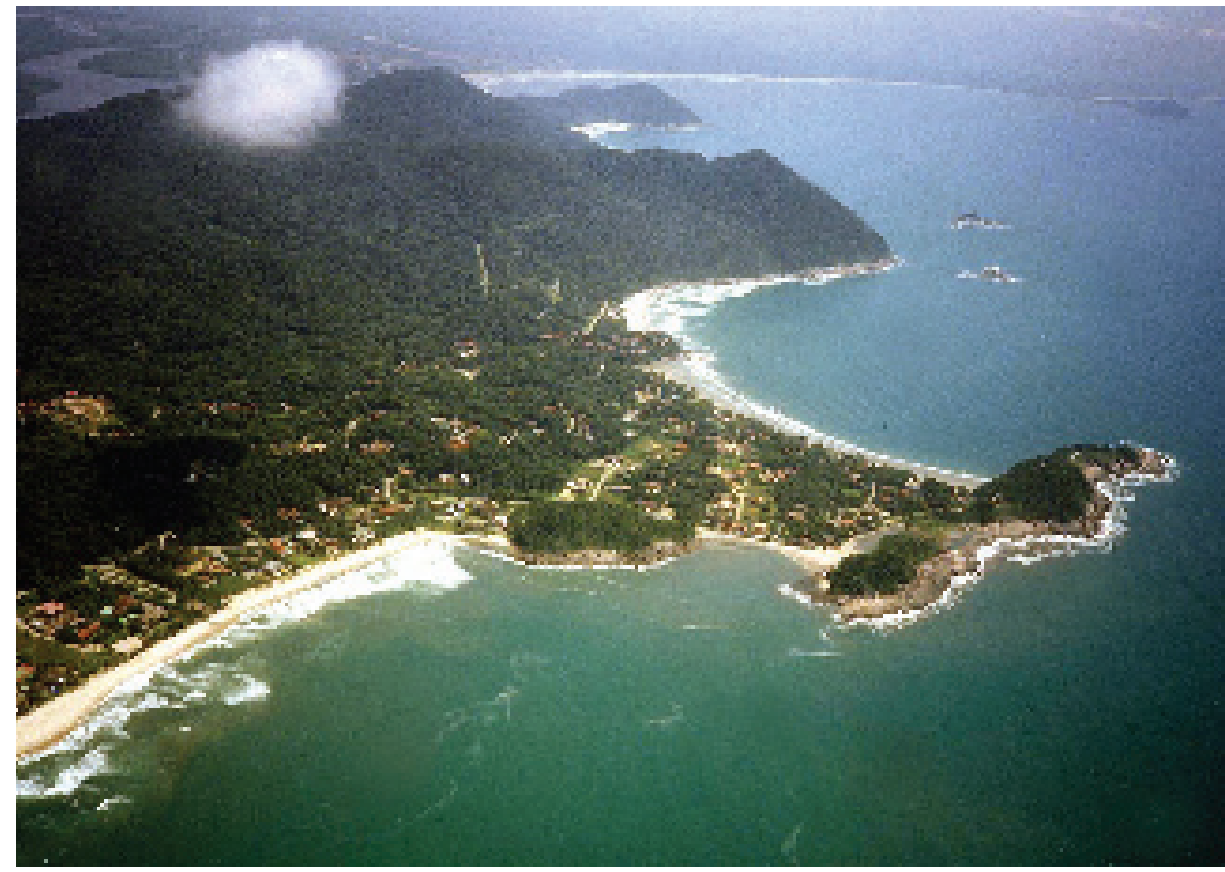

Foto 51:

Loteamento de alto padrão com acesso restrito ocupa as praias Grande e lporanga, privilegiando o isolamento e o contato com a natureza (Guarujá, 1998)

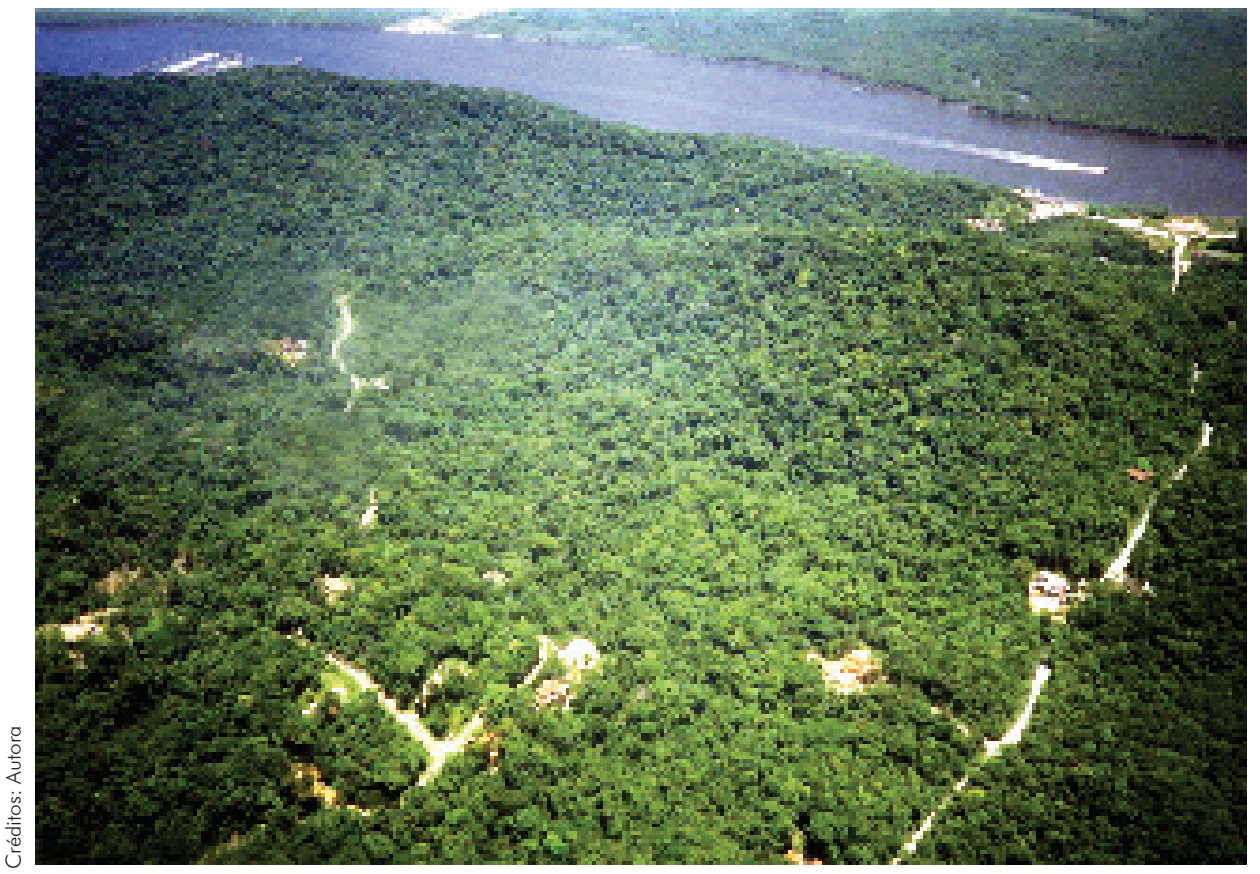

Foto 52:

O acesso ao loteamento se dá pela estrada Guarujá-Bertioga que margeia o canal (Guaruiá, 1999)

Nota-se ainda, no Canal de Bertioga, a presença de instalações náuticas para atracação de embarcações particulares de lazer, as marinas, por meio das quais se inicia uma nova forma de turismo que, ao invés da casa em frente ao mar, propõe, como turismo de alto padrão, a casa com píer particular para passeios de barco. Essas marinas que começam a disseminar-se na margem insular do canal (por onde passa a estrada a unir Guarujá a Bertioga) 
buscam suas águas calmas por conta das condições favoráveis à atracação das embarcações, retificando rios, aterrando manguezais e gerando mancha fragmentada e descontínua.

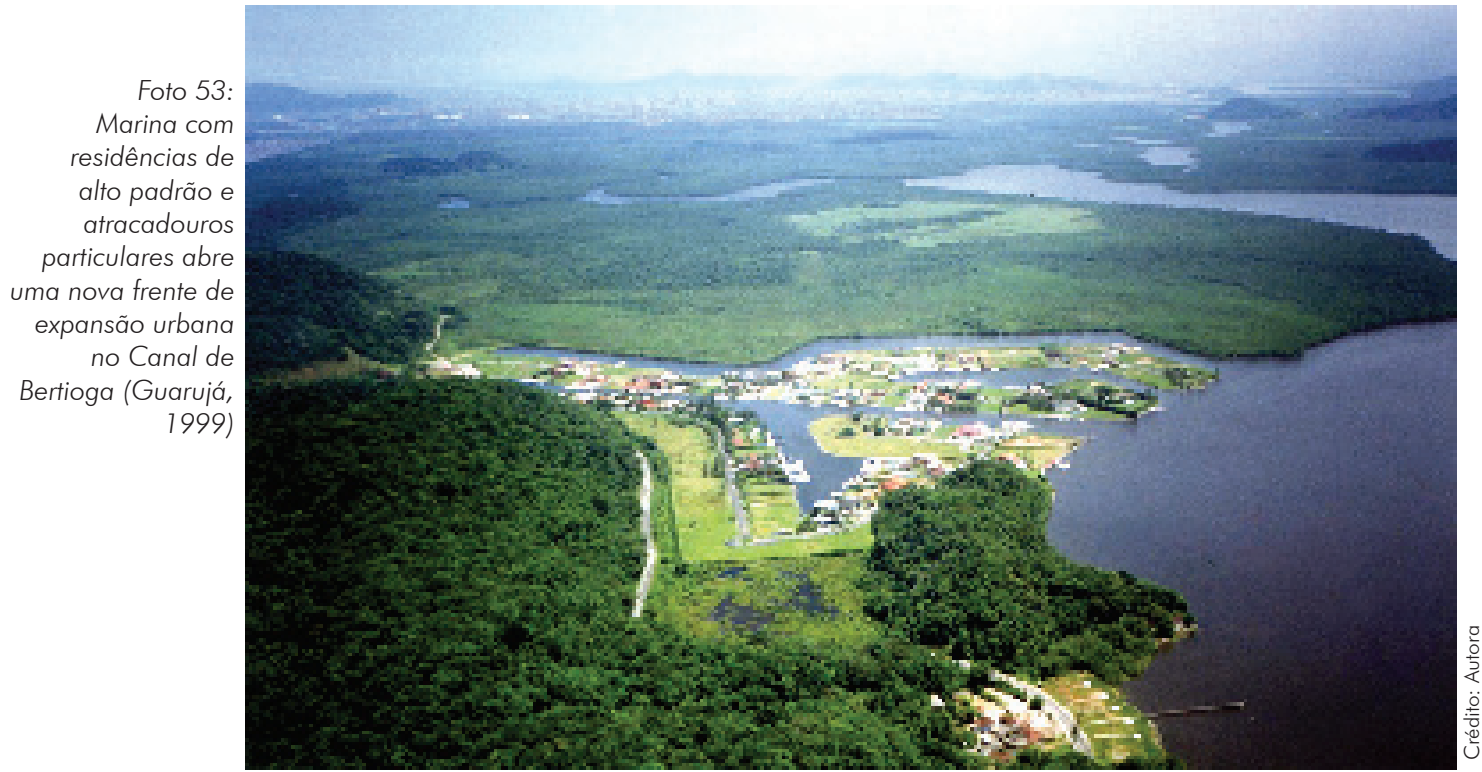

A ponta da Serra de Santo Amaro, próxima a Bertioga, ainda não foi alcançada pela expansão turística devido ao difícil acesso às praias (deve-se transpor a serra para atingi-las a partir da estrada) e à maior distância do núcleo urbano a partir do qual tem se dado a expansão urbana no Guarujá: a praia das Pitangueiras.

No entanto, a urbanização da llha de Santo Amaro não se deve apenas ao turismo. A ilha também recebe a expansão urbana de Santos, que transpôs o canal e ocupa sua margem oposta, onde se encontram assentamentos espontâneos sobre manguezais, áreas residenciais próximas à balsa e instalações náuticas (iate clube, estaleiros e centros de pesca) as quais buscam a proximidade do porto e do Canal de Santos. As instalações portuárias de Santos também se expandem no Guarujá, ocupando, agora, as duas margens do canal.

O distrito de Vicente de Carvalho também tem sua localização vinculada ao processo de transposição do canal pela urbanização santista. É bairro residencial bastante próximo ao centro de Santos e a ele ligado por um sistema de barcas que transporta rapidamente os trabalhadores residentes no distrito até seus locais de trabalho. Assim, a área urbana do distrito cresceu a partir do canal, expandindo-se rumo à rodovia Piaçagüera-Guarujá.

Encontram-se ainda áreas residenciais isoladas, habitadas por população de baixa renda, localizadas em terras de baixo custo, distantes do canal e das praias, porém em áreas de fácil acesso, tais como a variante da rodovia 


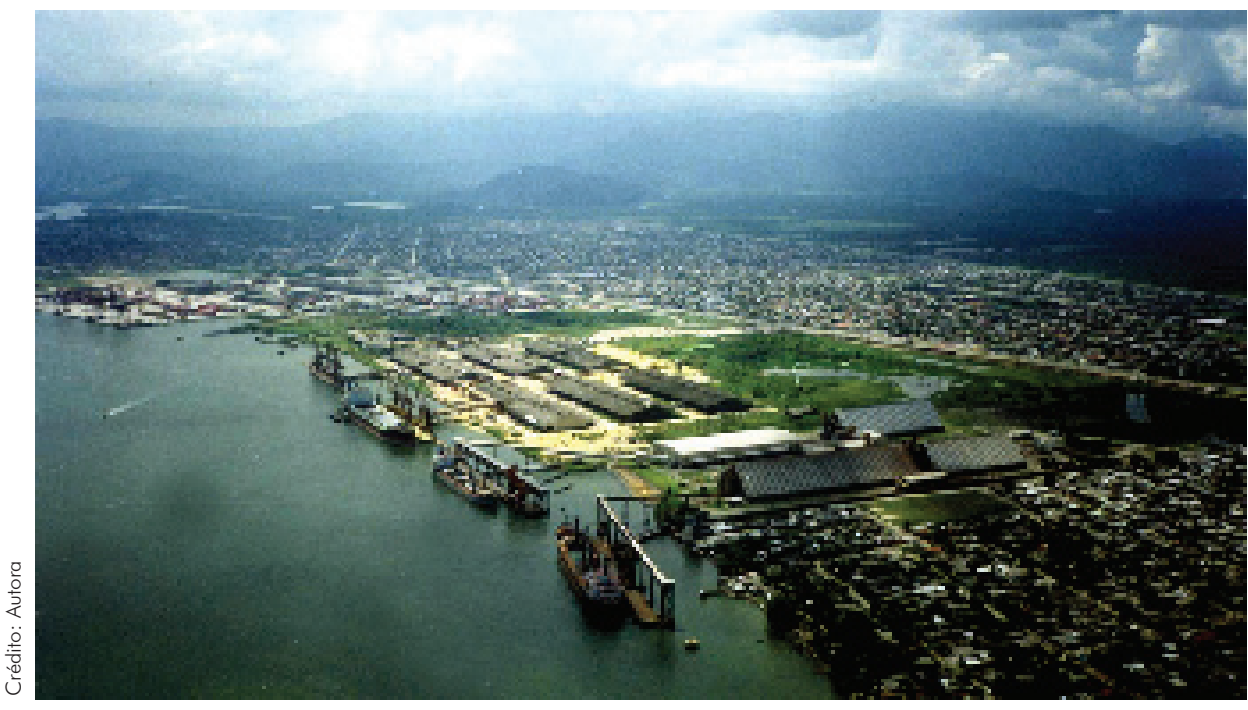

Foto 54:

Os terminais

portuários se

expandem na

margem do

Canal de Santos

pertencente ao

município de

Guarujá (Guaruiá,

1999)

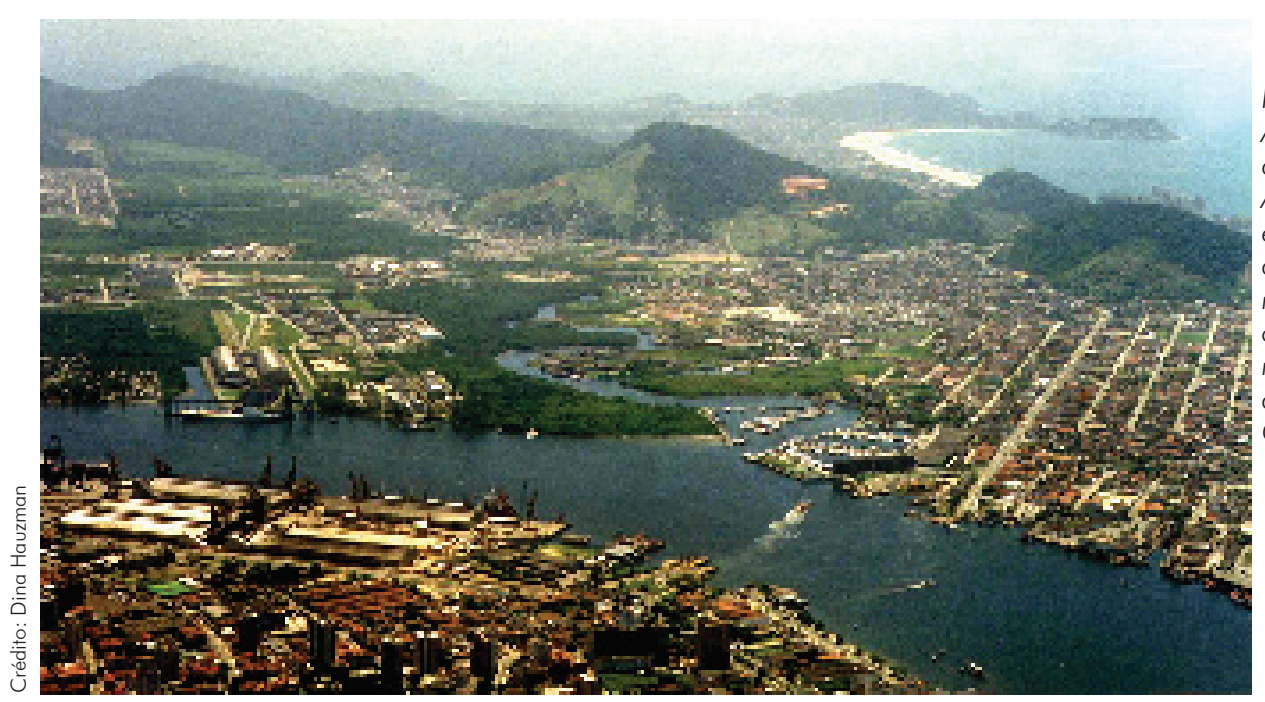

Foto 55:

A urbanização

da llha de Santo

Amaro vincula-se à

expansão urbana

de Santos: bairros

residenciais e o iate

clube se localizam

nas proximidades

da balsa Santos-

Guaruiá (Guaruiá,

1999)

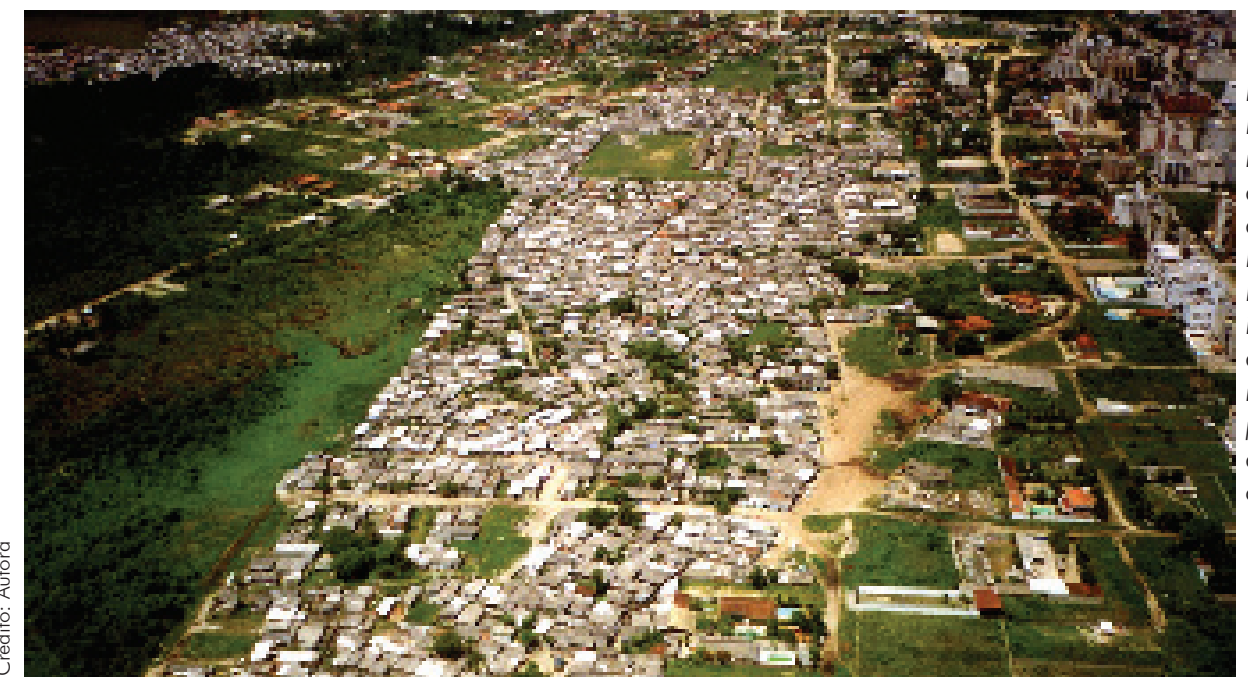

Foto 56:

Favela se localiza

nas proximidades

das áres turísticas

das praias da

Enseada e

Pernambuco,

indicando a busca

da proximidade

moradia-trabalho

pelos trabalhadores

das residências e do

comércio local 
Piaçagüera-Guarujá, a qual dá acesso à praia da Enseada. Manchas de ocupação espontânea também ocorrem nas proximidades das áreas turísticas, nas pontas menos valorizadas da mancha urbana, indicando a busca da proximidade moradia/trabalho pelos empregados das residências e edifícios de alto padrão.

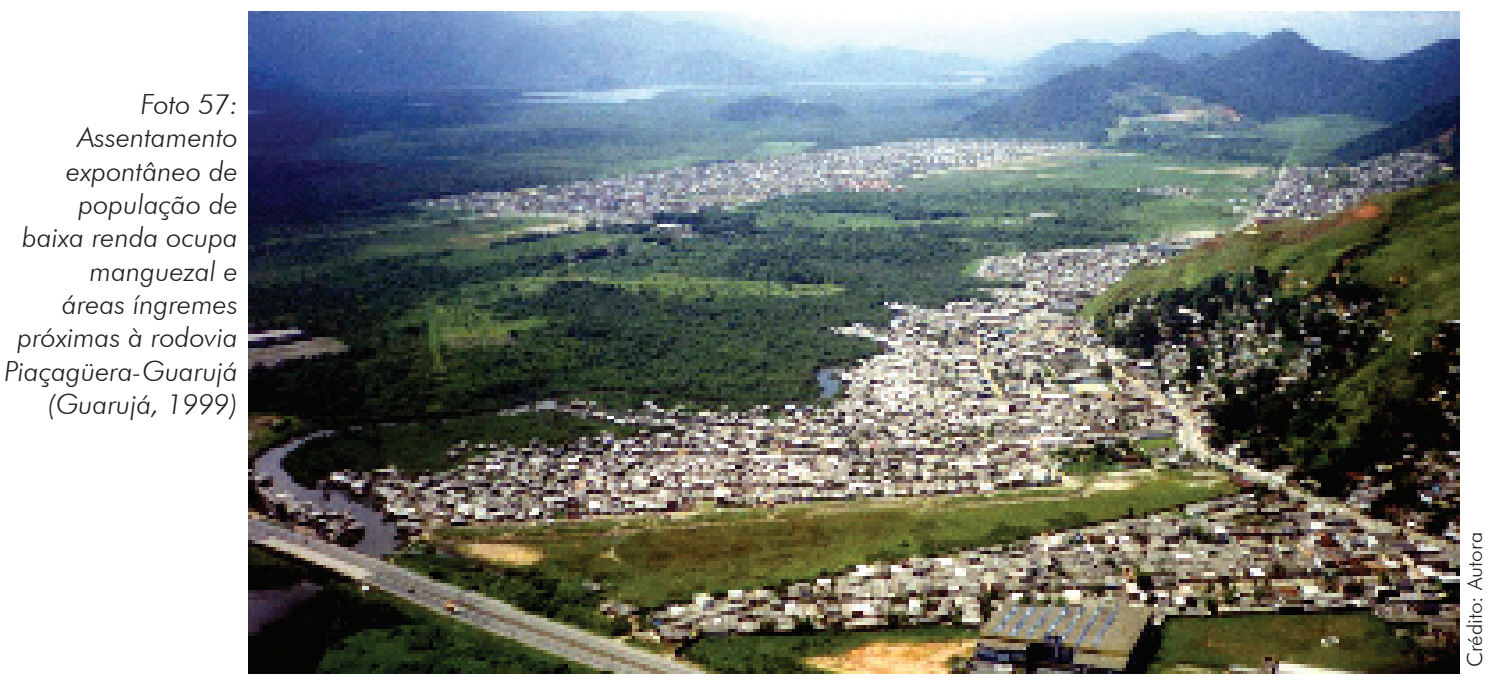

\section{Distribuição Espacial das Áreas Urbanas}

- mancha urbana linear contínua nas praias = atratividade das praias para lazer e moradia = predomínio do turismo

- adensamento linear nas praias = área de maior valorização

- mancha urbana linear e descontínua nos terrenos mais distantes da praia e adjacentes à área urbana = expansão urbana em áreas menos valorizadas

- mancha urbana contínua no Canal de Santos = expansão urbana de Santos

- mancha urbana descontínua nas estradas = acessibilidade em terras de baixo custo

- manchas urbanas fragmentadas = isolamento dos loteamentos de alto padrão + Canal de Bertioga como nova área turística

- áreas íngremes conservadas e praias não-ocupadas na ponta da Serra de Santo Amaro (em Bertioga) = dificuldade de acesso às praias e maior distância a percorrer

\section{Bertioga}

A área urbana mais antiga do município de Bertioga consiste em um pequeno núcleo próximo ao atracadouro da balsa que faz a travessia GuarujáBertioga. Sua expansão recente na praia provém da expansão do turismo, 
anteriormente, concentrado na praia Grande, Guarujá, Santos e São Vicente. Essa expansão turística se intensificou com a construção da via Prestes Maia (Rio-Santos), facilitando o acesso à região. A facilidade de acesso também valorizou as terras lindeiras à estrada, mas afastadas da praia, gerando novos loteamentos urbanos de ocupação ainda esparsa e a expansão do núcleo central de Bertioga na direção da nova rodovia.

Aqui, como nos demais municípios da Baixada Santista, a urbanização também se deu por loteamento isolado de glebas, por enquanto de ocupação esparsa, gerando uma mancha linear descontínua na praia com desenho do tipo colcha de retalhos.

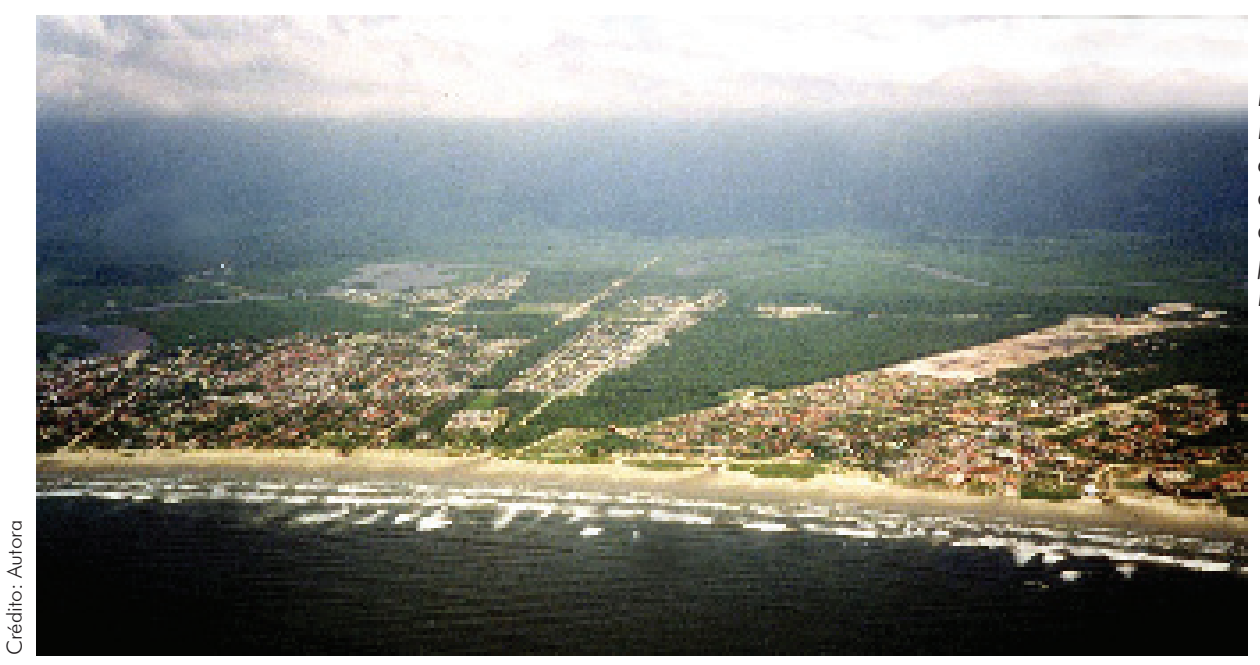

Foto 58:

Expansão turística em mancha linear descontínua ocupa a faixa de terra próxima à praia da Enseada (Bertioga, 1999)

\section{Distribuição Espacial das Áreas Urbanas}

- mancha urbana linear descontínua na praia = expansão turística recente

- mancha urbana descontínua na estrada = acessibilidade

\section{Conclusão}

Na região da Baixada Santista, a expansão descontínua das áreas urbanas tem feito com que as áreas pouco adequadas ao uso urbano como manguezais, encostas íngremes, afloramentos e costões rochosos, além de canais estuarinos, rios e contínuos florestais pouco alterados ainda constituam, no início do século XXI, um sistema de conservação "de fato" (não-oficial, vulnerável, mas existente) que ameniza variações climáticas, reduz risco de enchentes, melhora qualidade da água e do ar, conserva nutrientes e evita erosão do solo. Assim, os interstícios urbanos ainda existentes podem desempenhar importante papel, tanto para a manutenção dos hábitats quanto para as 
áreas urbanas, em um processo contrário ao atual, no qual predomina a eliminação sistemática dos remanescentes naturais para dar lugar a novos loteamentos urbanos.

Para isso, diretrizes, proposições e ações de intervenção urbana devem estar fundamentadas no conhecimento dos processos naturais e sociais e suas inter-relações. As soluções não devem repetir sempre os mesmos padrões urbanos, mas se fundamentar no conhecimento dos processos naturais locais e das conexões entre esses processos e a sociedade local, o que faz com que os padrões variem. Assim, cada proposta deve adequar-se ao lugar no qual se insere, não repetindo, como tem se verificado, o mesmo padrão de assentamento em qualquer parte.

\section{Bibliografia e Iconografia}

AFONSO, Cintia Maria. Uso e ocupação do solo na zona costeira do estado de São Paulo: Uma análise ambiental. São Paulo: Annablume/Fapesp, 1999.

BASE AEROFOTOGRAMETRIA E PROJETOS. Levantamento aerofotogramétrico da Baixada Santista. São Paulo: Base, 1994. esc. 1:25.000. 42 fotos.

BERTIOGA, Prefeitura Municipal. Secretaria de Obras. Planta do Município de Bertioga: Área litorânea. Bertioga, esc. 1:20.000.

CLARK, John. Coastal zone management handbook. Boca Raton: CRC, 1996.

CUBATÃO, Prefeitura Municipal. Secretaria de Planejamento. Planta Urbana 1. Cubatão, esc. 1:20.000.

$1: 20.000$.

. Secretaria de Planejamento. Planta Urbana 2: Áreas industriais. esc.

DEL RIO, Vicente. Introdução ao desenho urbano no processo de planejamento. São Paulo: Pini, 1990.

GOLDENSTEIN, Léa. A industrialização da Baixada Santista: Estudo de um centro industrial satélite. 1972. Tese (Doutorado) - Instituto de Geografia, Universidade de São Paulo. São Paulo, 1972.

GUARUJÁ, Prefeitura Municipal. Planta do Município do Guarujá. Guarujá. esc. 1: 10.000 .

GUTBERLET, Jutta. Cubatão: Desenvolvimento, exclusão social e degradação ambiental. São Paulo: Edusp/Fapesp, 1996.

LYLE, John Tillman. Design for human ecosystems: Landscape, land use and natural resources. Nova York: Van Nostrand Reinhold, 1985.

MACEDO, Silvio Soares. Paisagem, urbanização e litoral: Do éden à cidade. 1993. Tese (Livre-docência) - Faculdade de Arquitetura e Urbanismo, Universidade de São Paulo. São Paulo, 1993. 
MACEDO, Silvio Soares. São Paulo, paisagem e habitação verticalizada: Os espaços livres como elementos de desenho urbano. 1987. Tese (Doutorado) - Faculdade de Arquitetura e Urbanismo, Universidade de São Paulo. São Paulo, 1987.

McHARG, lan L. Design with nature. Nova York: Doubleday/Natural History, 1971.

MEDEIROS, Diva B. Guarujá. In: AZEVEDO, Aroldo de (Org.). A Baixada Santista: Aspectos geográficos. São Paulo: Edusp, 1965.

PRAIA GRANDE, Prefeitura Municipal. Secretaria de Planejamento de Obras. Planta geral do município. esc. 1:10.000.

PUBLIMAP. Planta polivisual das cidades de Santos e São Vicente. Guarulhos, Publimap. esc. $1: 12.500$.

SÃO PAULO (Estado). Instituto Geográfico e Geológico. Cartas da Região Sul do Brasil. São Paulo: Iggsp, 1971. esc. 1: 50.000.

Secretaria do Meio Ambiente. Cetesb. Baixada Santista: Carta do meio ambiente e de sua dinâmica: memorial descritivo. São Paulo: Cetesb, 1985. esc. $1: 50.000$.

SÃO VICENTE, Prefeitura Municipal. Secretaria de Obras. Planta do Município de São Vicente. esc. 1:10.000.

\section{Fotografias}

As fotografias, com exceção daquelas cuja autoria é citada no texto, foram feitas pela autora deste trabalho em dois sobrevôos, realizados em janeiro de 1998 e março de 1999. 